\title{
FILLING THE GAPS
}

Reimagining Public Space as a Continuum

\begin{abstract}
by
Analiz Ochoa

A thesis submitted to the Faculty of Graduate and Post Doctoral Affairs in partial fulfillment of the requirements for the degree of

Master in Architecture

Carleton University

Ottawa, Ontario, Canada
\end{abstract}

(C) 2021

Analiz Ochoa 


\section{ABSTRACT}

There is a special joy found in the gaps of time and space along the street-a possibility to dream, wonder, or suddenly encounter the unexpected. Yet, these moments are rapidly disappearing from the urban fabric as our streets undergo a process of erosion. Like the river eating its bank, the public realm is flaked away by traffic, congestion, and private interests.

Who owns public space? To address this question, Filling the Gaps reflects on the agency of the street and the different actors that come into play. How can the notion of public and private be reconceptualized to open-up urban spaces to city-users? This thesis discovers the missed opportunities for 
interactions with and within the city by observing Ottawa's street life. How can the street be transformed from a space

of passage alone to a space for connection and human interaction? Four dismissed and unseen urban gaps are chosen to explore the possibilities of publicness along the street. How can a continuum streetscape for public life emerge within the city? Through tactical interventions and urban storytelling, the project reimagines a process where urban dwellers renegotiate and extend the public realm's boundaries. 


\section{ACKNOWLEDGEMENTS}

To my mom and dad, for your guidance, for your unconditional support and for providing me with all the tools I needed get to the position I am in today. No words would ever explain the gratitude I have for all the sacrifices both of you made.

To Rami, for being present in the day-to-day and proving your constant support. Thank you for accompanying me to explore the city and for all the thoughtful conversations that developed along the way.

To my advisor, Federica Goffi, for your continual guidance and kind words of reassurance through this remarkably 
viii Filling the Gaps

difficult year. Your brilliant ideas and immense knowledge

helped and encouraged me to produce this project.

To all my family and friends, for all the help and motivation you have given me through my career as a student.

To all the dwellers living along Bank Street, for allowing me

to document their day-to-day for this work. 


\section{TABLE OF CONTENTS}

$\begin{array}{ll}\mathrm{iii} & \text { Abstract } \\ \mathrm{vii} & \text { Acknowledgements } \\ \mathrm{x} & \text { Table of contents } \\ \mathrm{xii} & \text { List of figures } \\ & \\ 1 & \text { Prologue } \\ 3 & \text { Introduction }\end{array}$

\section{DISMISSED SPACES}

1.1 Life Along the Street

1.2 The Street as the Foundation

1.3 The Street in the Time of Covid

\section{A WALK ALONG THE STREET}

2.1 The Street: Public Life on Bank Street

2.2 The Three Neighbourhoods: Centertown, the Glebe and Old Ottawa South

2.3 Unpleasant Design

2.4 The Gap Typologies: Corner, Storefront, Alley, Parking Lot
PART THREE

67

79

\section{STREETS OF TOMORROW}

3.1 Emergence: A New City-User

3.2 Tactical Urbanism: the Poblenau Superblock

3.3 Gap Transformation: Corner, Storefront, Alley, Parking Lot

3.4 Reimagining Public Space as a Continuum in Ottawa

Conclusion
Endnotes

Bibliography 


\section{LIST OF FIGURES}

Figure 0.1 - Bächle in Freiburg, Germany, Photograph by David Sims, Soft City, (Washington:

Islander Press, 2019), 190

Figure 0.2 - Karl Jilg/Swedish Road Administration, Illustration by Karl Jilg, accessed November 03, 2020, https://www.vox.com/xpress/2014/11/18/7236471/cars pedestrians-sidewalks-roads

Figure 1.1 - Two boys along Bank Street and Fourth Avenue, Photograph by Analiz Ochoa, October 2020.

Figure 1.2 - Model of Carlo Felice Theater, Genoa, Italy, Designed by Aldo Rossi, 1991, accessed November 03 2020, https://www.artsy.net/artwork/aldo-rossi-il-teatro-carlofelice-di-genova

Figure 1.3 - Hester Street, Photograph by Maurice Branger, in Joseph Stomberg, "The forgotten history of how automakers invented the crime of 'jaywalking,"' Vox, accessed January 05, 2021, https://www.vox.com/2015/1/15/7551873/jaywalking-history

Figure 1.4 - A summer day in Byward Market Square, Photographed by Analiz Ochoa, October 2020.

Figure 1.5 - A fall day in Clarence Street and Byward Market Square, Photographed by Analiz Ochoa, October 2020

Figure 2.1 - Bank Street's neighbourhoods map, Illustration by Analiz Ochoa, March 2020. Figure 2.2- Bank Street along the Centertown neighborhood, Illustration by Analiz Ochoa, October 2020.

Figure 2.3-Community street garden outside the Centertown United Church, Photograph by Analiz Ochoa, October 2020

Figure 2.4 - Empty lot enclosed by a metal fence between 136 and 152 Bank Street, Photograph by Analiz Ochoa, October 2020.

Figure 2.5- Bank Street along the Glebe neighborhood, Illustration by Analiz Ochoa, October 2020.

Figure 2.6- The Patterson's Creek Park intersection opens-up views of the park, Photograph by Analiz Ochoa, October 2020

Figure 2.7- Alley besides 745 Bank Street, Photograph by Analiz Ochoa, October 2020. Figure 2.8- Bank Street along the the Old Ottawa South neighborhood, Illustration by Analiz Ochoa, October 2020.

Figure 2.9- Storefront at 1063 Bank Street, Photograph by Analiz Ochoa, November 2020. Figure 2.10 - Open corner between Belmont Street and Bank, where the Sri Chinmoy Meditation Centre has placed a cluster of benches and planters around a small monument, Photograph by Analiz Ochoa, October 2020. 
Figure 2.11 - Bench on Bank Street and Waverly Street W, Photograph by Analiz Ochoa, September 2020.

Figure 2.12 - "Archisuits," Artwork by Sarah Ross, accessed November 21, 2020. https:// www.insecurespaces.net/archisuits.html.

Figure 2.13- Gap along Bank Street between Henry's and Alterna Savings, Photograph by Analiz Ochoa, September 2020

Figure 2.14- A boy on the sidewalk, Photograph by Analiz Ochoa, September 2020.

Figure 2.15 - Collection of corners along Bank Street, Photograph by Analiz Ochoa, September 2020.

Figure 2.16 - Collection of storefronts along Bank Street, Photograph by Analiz Ochoa, September 2020.

Figure 2.17- Collection of alleys along Bank Street, Photograph by Analiz Ochoa, September 2020

Figure 2.18 - Collection of surface parking lots along Bank Street, Photograph by Analiz Ochoa, September 2020

PART THREE

STREETS OF TOMORROW

Figure 3.1 - Eliza and Adela Andrew's Lemonade stand, by Kurtis Andrews, in Idil Mussa, "Where's Your Permit? Children's Lemonade Stand Shut down in Ottawa," CBC, July
3, 2016, https://www.cbc.ca/news/canada/ottawa/ottawa-ncc-shuts-down-lemonadestand-1.3662830.

Figure 3.2 - Poblenou superblock in its original, temporary-feeling form in 2016 Photograph by BCNUEJ, in David Roberts, "Barcelona Wants to Build 500 Superblocks. Here's What It Learned from the First Ones.," Vox, April 9, 2019, https://www.vox.com/energy-andenvironment/2019/4/9/18273894/barcelona-urban-planning-superblocks-poblenou.

Figure 3.3 - Architecture on the edge of the Poblenou superblock, Photograph by Maysun, in David Roberts, "Barcelona Wants to Build 500 Superblocks. Here's What It Learned from the First Ones." Vox, April 9, 2019, https://www.vox.com/energy-andenvironment/2019/4/9/18273894/barcelona-urban-planning-superblocks-poblenou.

Figure 3.4 - Map showing the gap interventions along Bank Street, Illustration by Analiz Ochoa, March 2020

Figure 3.5- L'Esplanade building along the intersection of Bank Street and Laurier Avenue, Ottawa, Photograph by Analiz Ochoa, October 2020

Figure 3.6 - Corner intervention as a gathering plaza, Illustrated by Analiz Ochoa, January 2020

Figure 3.7 - Transition of corner intervention, Illustrated by Analiz Ochoa, January 2020

Figure 3.8- Wallack's storefront at 231 Bank Street, Ottawa, Photograph by Analiz Ochoa, October 2020.

Figure 3.9 - Storefront intervention as an area to stop and stay, Illustrated by Analiz Ochoa, January 2020. 
Figure 3.10 - Transition of storefront intervention, Illustrated by Analiz Ochoa, January 2020

Figure 3.11 - A section through the storefront intervention, Illustrated by Analiz Ochoa, January 2020.

Figure 3.12 - Alley in the Glebe within the block of Bank Street and Fourth Avenue, Ottawa, Photograph by Analiz Ochoa, October 2020.

Figure 3.13 - Alley intervention as a staircase that leads people to inhabit the roof tops, Illustrated by Analiz Ochoa, February 2020.

Figure 3.14 - Transition of alley intervention, Illustrated by Analiz Ochoa, February 2020.

Figure 3.15 - Side elevation of the alley intervention, Illustrated by Analiz Ochoa, February 2020

Figure 3.16 - Parking lot outside of the Old Ottawa South Public Library, Ottawa, Photograph by Analiz Ochoa, October 2020

Figure 3.17 - Parking lot intervention as a children playground, Illustrated by Analiz Ochoa, February 2020.

Figure 3.18 - Transition of parking lot intervention, Illustrated by Analiz Ochoa, February 2020

Figure 3.19-As interventions emerge along the street a continuous public space is fostered, Illustrated by Analiz Ochoa, March 2020.

Figure 3.20 - An emerging intervention of a restaurant's storefront, Illustrated by Analiz Ochoa, March 2020.
Figure 3.21 - Block of Bank Street and Third Avenue as it stands to date, Illustrated by Analiz Ochoa, March 2020.

Figure 3.22 - Street gaps are filled with tactical interventions that invite people to engage with the street, Illustrated by Analiz Ochoa, March 2020.

Figure 3.23 - With time as the design interventions spread onto every city gap, a public space continuum is conceived, Illustrated by Analiz Ochoa, March 2020.

Figure 3.24 - An emerging intervention of a street park, Illustrated by Analiz Ochoa, March 2020. 


\section{PROLOGUE}

People watching, those ones passing

Through the center, life unfolds at last

Time is running; the, day is starting

At the edges, the audience is looking

On the asphalt, cars are moving fast

People watching, no space for gathering

No resting places, no art for glaring

Dismissed and unseen, the streets at vast

Time is running; the, day is changing

In-between spaces, only for parking

No site for wonder, in soft contrast

People watching, but no one is pausing

A lonely culture, of mindless walking

Upon the city, solitude was cast

Time is running, the day is fading

The streets are empty, no life for staging

Like the paths of a time long past

People-watching, those ones leaving

Time is running, the day is ending 


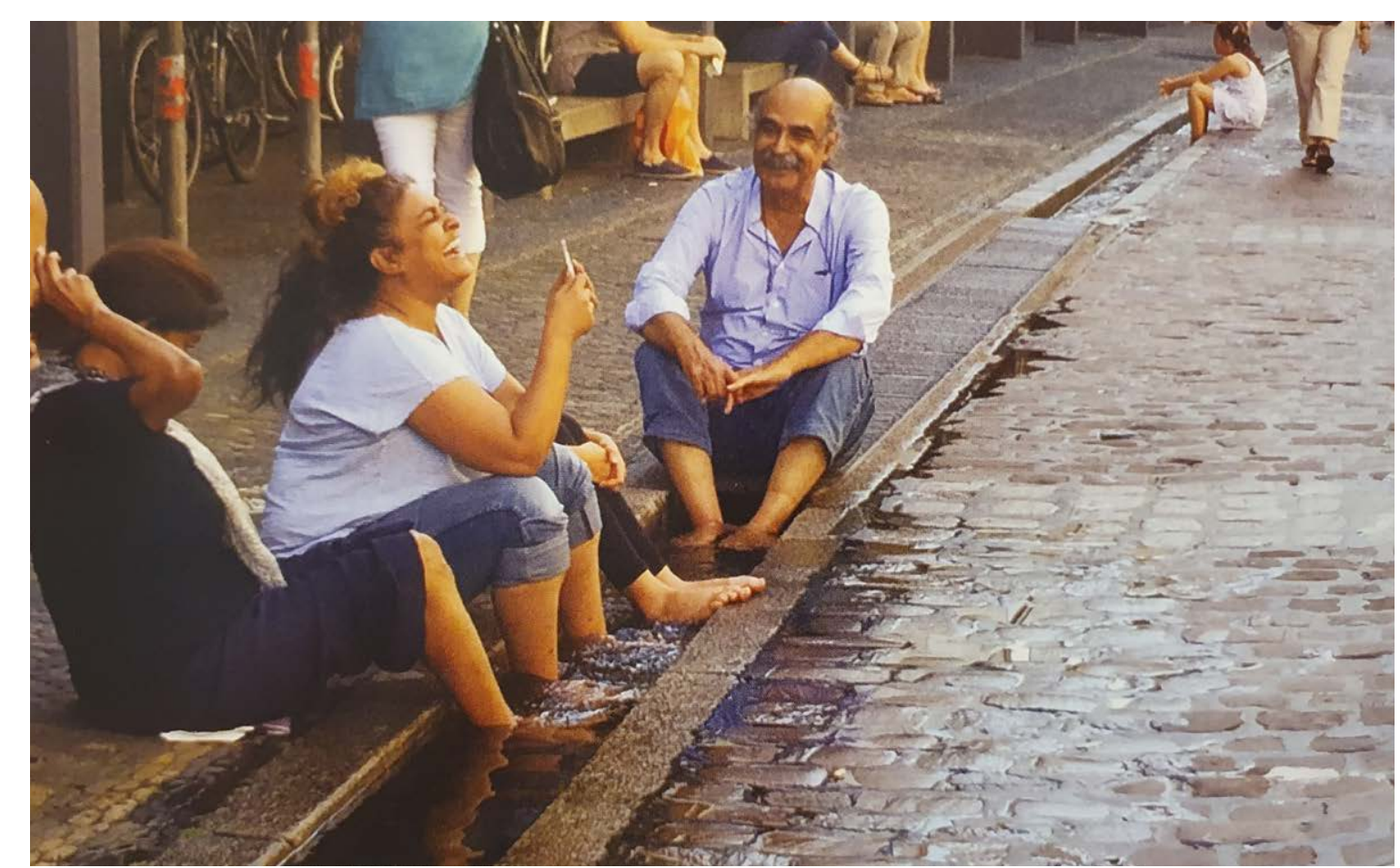

Figure 0.1 - Life along the

street, Bächle in Freiburg,

\section{INTRODUCTION}

Four people chat and laugh along the edge of a water channel in Freiburg, Germany (figure 0.1). Walking through the city on a warm summer afternoon, they have found an opportunity to rest and refresh in this urban feature. Far back, in the same channel, a little girl has discovered space for reflection, or perhaps a space to wait for her friends to come and play. On each side of the channel, other people continue walking, uninterrupted through their daily paths. While others sit at the edge of the street gazing at those passing by.

Pedestrians can find a special joy in the gaps of time and 
space along the street-a possibility to dream, wonder, or suddenly encounter the unexpected. In the city, streets behave like the backdrop for urban life. As people move along the day, those at the edges watch the play of life unfold. Some actors walk on the sidewalk, while others exit the stage through thresholds. However, a few dare to partake in activities not originally prescribed to the grid. In the book Loose Space, architecture professor and environmenta psychologist Karen Frank and urbanism professor Quentin Stevens observe the various ways people appropriate public space in the city for "leisure, entertainment, self-expression or political expression, reflection and social interaction -all outside the daily routine and the world of fixed functions and fixed schedules."

Unfortunately, in North American cities, these unprescribed activities are rapidly disappearing from the urban fabric, as many streets undergo a process of erosion. Since the automobile's invention, urbanists and architects have been planning the city to accommodate vehicles leaving little public space for people to inhabit. Artist Karl Jilg's satirical depiction of the street as a deep ravine illustrates narrow sidewalks and wavering planks restricting pedestrian movement (figure

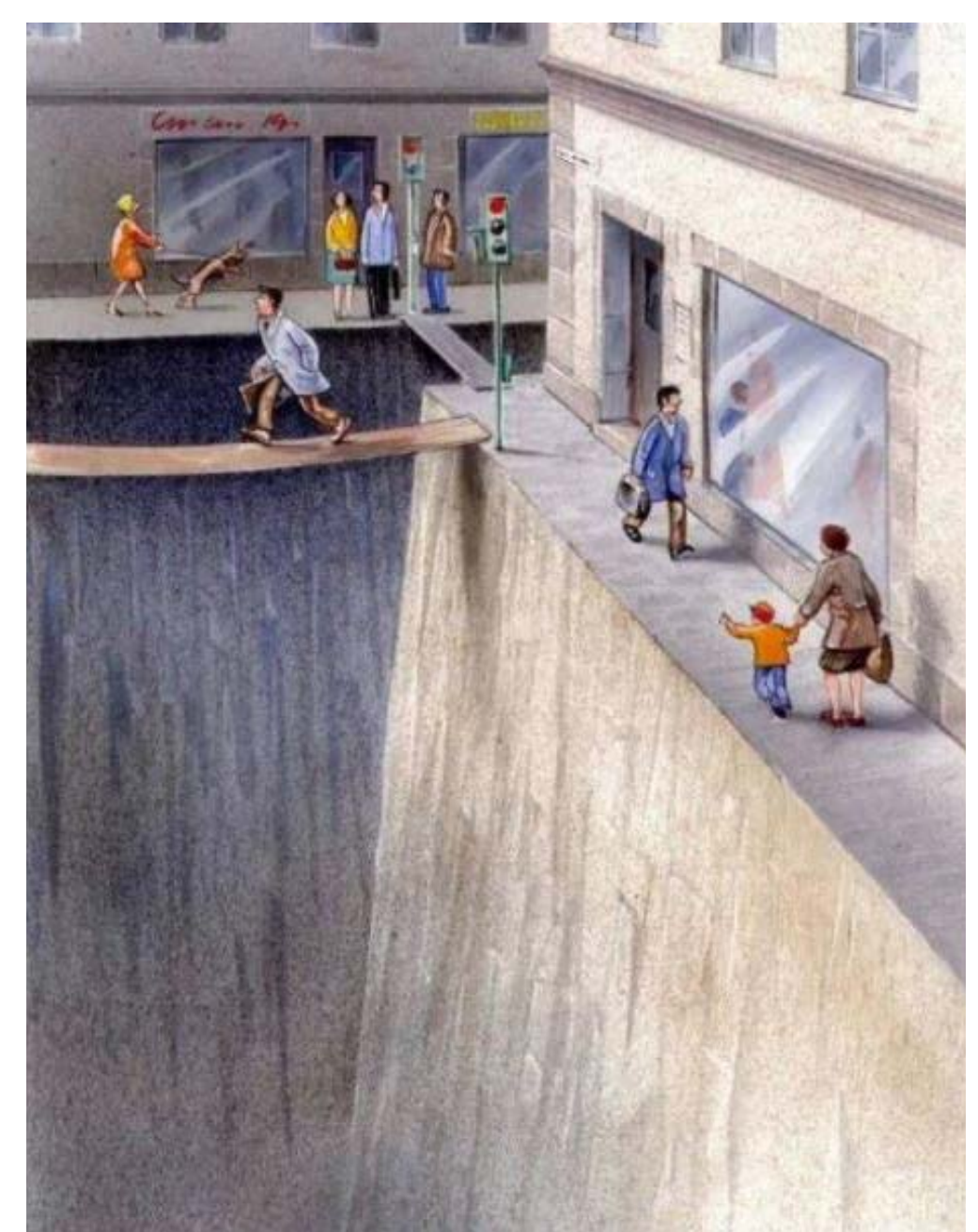

Figure 0.2 - Artist Karl ravine. () Illustration by Karl Jilg comissioned by the Swedish Road Aministration. 
0.2). Streets are valued for their circulation capabilities, serving only to link segregated functions. However, as a public network, streets have the potential to do more than connect people with a destination; they can also provide opportunities to connect people with themselves, with each other, and the city.

As any Western modernist-planned municipality, Ottawa suffers from segregated zones and functions. The physical spread of amenities has promoted vehicular congestion on the streets. Moreover, by prioritizing cars, public spaces for people to occupy have been reduced to a minimum. Nevertheless, a projected population growth of $40 \%$ from 2018 to 2046 has compelled the municipality to redraft the city's New Official Plan. ${ }^{2}$ The population jump makes an increase in vehicular congestion unfeasible, so the time has come to give streets back to the people. The New Official Plan addresses the need for a more engaging and livable urban fabric that fosters sustainable forms of transportation, healthy and inclusive communities, and culture propagation. ${ }^{3}$ But how can this be achieved when through the years, as public space was flaked away, city-users were deterred from using streets?
Filling the Gaps looks at the street's spatial linearity physical proximity and accessibility to all as an opportunity for a public life continuum to emerge within the urban fabric. The project develops along Bank Street in Ottawa, which is chosen as a case study; however, to achieve the public realm's continuity, the whole city's network must be considered. The design approach developed on this particular artery could unfold throughout any city street resulting in unique interventions for every street corner and gap -or enough street corners and gaps to create a significant change-, fostering a continuum in the urban fabric.

Bank Street crosses Ottawa from North to South. The artery stands as a major socioeconomic backbone in the city, along the three neighbourhoods closest to the downtown core: Centertown, The Glebe, and Old Ottawa South. The conditions of Bank Street in these three neighbourhoods are ideal for public life to emerge. There is a high-density population without the overpowering high-rise built forms, which allows for a sense of human scale, and a diversity of uses - office buildings, grocery stores, clothing shops, schools, houseswithin walking distance from each other. Therefore, this thesis identifies the potential to 'fill in the gaps' to revitalize 
streets and foster social interaction. As a way to exemplify the typologies of gaps and potential of interventions along the downtown streets, this thesis provides design insight on four gaps along Bank Street located within the limits of one of these neighbourhoods. Each space characterizes different socioeconomic and spatial conditions. Such gaps classify as dismissed and unseen spaces of unexplored potential as the current uses do not fulfill their role within the urban fabric.

The project develops a different urban narrative for each site to construct a new spatial identity through tactical interventions. The goal is to attract the community to these spaces with flexible and playful interventions that users can change or adapt depending on their needs. By engaging people with the urban fabric, a new city-user can emergethe urban dweller. One that takes ownership, adds value and protects the interests of the public realm. As the new city-user inhabits and interacts with the gaps, unprescribed activities will again occupy the city's network, making it more likely for public spaces to spread and foster the potential for social interaction. By filling every gap along the street with spaces that encourage publicness, a continuous public realm is re-conceived out of the existing network of downtown streets 


\section{DISMISSED SPACES}

THEMES \& RESEARCH 
Figure 1.1 - Two boys

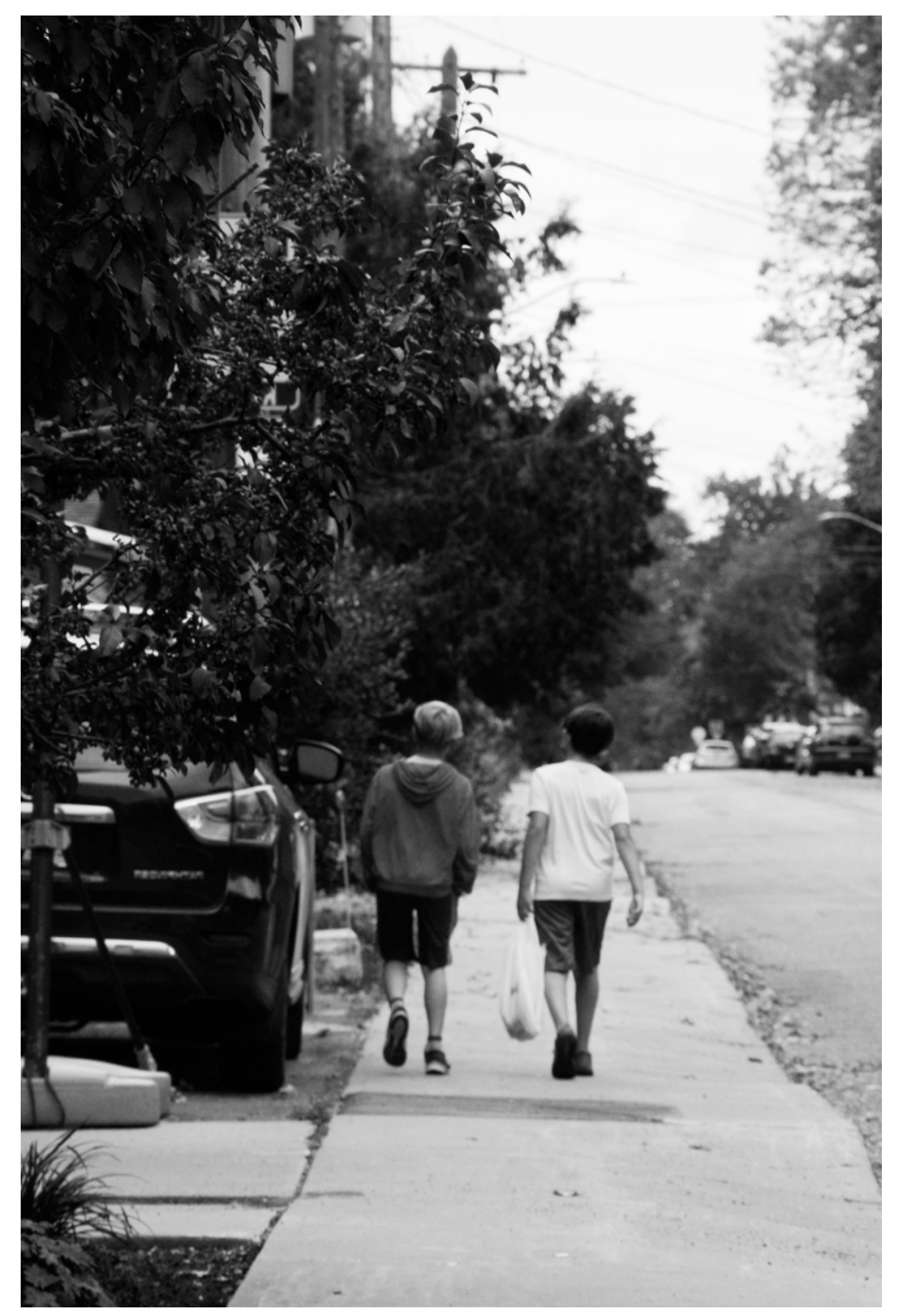

\subsection{PUblic LIfE ALONG the StREet}

A girl holding hands with her father points at the blueberry danishes that two young women enjoy sitting along the bakery shop's edge. The baker is outside, handing a closed package to a tall man standing next to the shop's door. The baker removes her mask, and the two discuss the challenges their children have experienced with online learning. Both hoping schools open-up once fall comes-an older woman passes-by walking a chocolate Goldendoodle, slightly smiling at the pair. A young man on the sidewalk across holds a camera up to take a picture of the dog. The older woman waves at him and shouts: "looking to buy a puppy?" Behind him, two boys, with a look of mischief, burst out of the candy shop. Laughing, they run to pet the Goldendoodle. After some play, the two boys walk back home side-by-side, guarding a candy bag in-between. 
The story above is fictional, written while observing life on Bank Street one summer day of 2020 during one of the author's site visits. Although all these characters were present in the same space simultaneously, these interactions did not occur. After buying the blueberry danishes, the two young women walked away from the bakery as there was no space to sit and chat. The little girl passed-by a few minutes later, but there were no danishes to see. The baker gave a package to the man standing outside the shop; the man asked the baker about her child but quickly left the scene as he saw the women with the Goldendoodle coming along. There was not enough space on the sidewalk for all these characters to maintain a 6-feet separation, which was a COVID-19 restriction imposed by the municipality to prevent the spread of the pandemic that broke worldwide in 2020. The woman with the dog was wearing a mask that covered her mouth, so even though she glanced at the baker, it is hard to tell if behind the mask hid a saluting smile. The young man on the sidewalk across tried to take a picture of the Goldendoodle, but he struggled as the cars passing-by obstructed the view. And finally, the two boys walked straight back home after running their errands, as the street did not seem like a safe place to play with the dog (figure 1.1)
The lack of interactions and public life observed in North American urban centers has been a topic of study among scholars, urbanists and city councillors for decades. In the 1960s, a critical voice emerged —urban writer Jane Jacobs (1916-2006) - with her book Death and Life of Great American Cities. She presented a vision of a city made for people that contrasted with the principles and ideals of the most influential urban planners, architects and city councillors at the time. ${ }^{4}$ Jacobs' observations opened the door to the study of public life, influencing many scholars' work, including professors Karen Frank and Quentin Stevens. However, even though academics have broadly discussed the importance of public life, North American cities have failed to implement adequate solutions to develop urban public spaces.

While North American urban planners and city councillors dismissed Jane Jacobs' principles, in Europe, architect and urbanist Jan Gehl meticulously observed and recorded public life. In 1971 Gehl presented his findings on Life Between Buildings. ${ }^{5}$ In 2000 Jan Gehl founded the Danish firm Gehl Architects to spread his early research and ideas of people- 
centred urban design. Today, Gehl's unique understanding of public space's quality and design conditions is visible in many contemporary European urban models like the Barcelona Superblock in Spain, which will be further discussed in part three of this thesis.

Let us go back to the description of life on Bank Street presented at the beginning of this section and revisit it together with Gehl's design theories and principles to uncover the missing elements in this urban space. According to Gehl, for streets to host public life, they must accommodate infrastructure for three main activities to unfold: necessary, optional, and social activities. ${ }^{6}$ Necessary activities are those imperative to the space in which all participants engage. ${ }^{7}$ Moving from one place to another represents a necessary activity within the street. This action was performed by all of the characters in the story above. Other necessary activities can be commercial, especially along main streets, which often form a neighbourhood's economic backbone. ${ }^{8}$

Although all streets allow for some form of circulation, most lack the infrastructure to support optional and social activities. Optional activities are pursued voluntarily. Only if the space is attractive and available, ${ }^{9}$ two qualities that ordinary North American urban streetscapes often lack. These activities include taking a walk at lunchtime, standing outside under the sun, or sitting down while eating a danish. Social activities are those that have not been prescribed by the grid but rather emerge as associated activities of the other two categories. ${ }^{10}$ In the description above, social activities were interrupted by a lack of infrastructure, space and security along the street. The two young women did not find a sitting area to eat and chat. There was no space on the sidewalk for the baker and the man to start a conversation. And the cars on the street discourage both the photographer and the kids from pursuing new ventures. Many streets today lack social connections. A lack of interactions at the street level means a reduction of social cohesion among the neighbourhood. Besides the economic stagnation empty streets generate, the absence of social connections can also lead to fracture communities. 
"Streets and their sidewalks, the main public spaces of a city, are its most vital organs. Think of a city and what comes to mind? Its streets. If a city's streets look interesting, the city looks interesting; if they look dull, the city looks dull.".11

\subsection{THE STREET AS THE FOUNDATION}

In Death and Life of Great American Cities, Jane Jacobs compares cities to a living organisms. In this metaphor, streets form the circulation network through which the city's life flows. Therefore, streets are a fundamental unit of public space making-up the city; they weave into neighbourhoods, which then agglomerate together to shape a broader ecosystem. ${ }^{12}$ Within the city, streets determine "the security, the social cohesion and economic development" of the whole. ${ }^{13}$ As with anything in nature, events at the microscale produce effects on the macro scale. In North American cities, vehicular circulation has become the primary focus for street design. By diminishing streets to transit networks, cities have been impaired with congestion and segregation, 
reducing spaces for public life. ${ }^{14}$

As a result, the street image is distorted as a two-dimensional surface only to be used by vehicles to move, forgetting about the other multiple layers of spaces that compose it. Perpendicular to the ground plane, the building's edge rises. The threshold accommodates the various activities that attract people to the street. Parallel to the roadbed, there is the sidewalk where people move and interact with one another. Through this layer, pedestrians can experience the city and identify themselves in it by feeling the textures defining the edge, perceiving the mixing scents, and listening to the melody of the everyday. The sky and foliage make up the top plane, connecting people with nature, the passage of time and the changing seasons.

Observing Ottawa's morphology, it is possible to notice specific destinations where people can connect with the city and outdoor communal activities can occur. The Byward Market, Major's Hill Park and the Lansdowne complex, for example, are destinations where different groups of people can gather around. While these spaces allow for lingering, they are considered arrival points rather than places of passage and transit. In this city, inhabitants must travel to specific destinations to find space for public life. In contrast, in this thesis, it is argued that the urban fabric should be the one providing a continuum space for publicness to emerge at every street corner and along their paths.

The etymology of the word street derives from the Latin root stere- which translates to "spread, extend, stretch out." ${ }^{\prime \prime}$ Throughout history, streets have played the role of connectors, stretching and extending city life from indoors to outdoors, and private to public. The Carlo Felice Theater in Genoa, Italy, stands as an example of this urban pattern. This theatre was designed in 1827 by Carlo Barabino (1768-1835) and rebuilt by Aldo Rossi (1931-1997) after the Second World War destroyed its interiors. Within the theatre's footprint, an indoor public plaza connects to the street, granting the public realm permeability to the building's inside (figure 1.2). Before the automobile's rise, North American city's images also show streets as spaces for private life extension. Back in 1914, streets were occupied by people, and everyday activities unfolded along these spaces. Streets represented a place for children to play, small merchants to sell goods and dwellers to gather around (figure 1.3). ${ }^{16}$ 


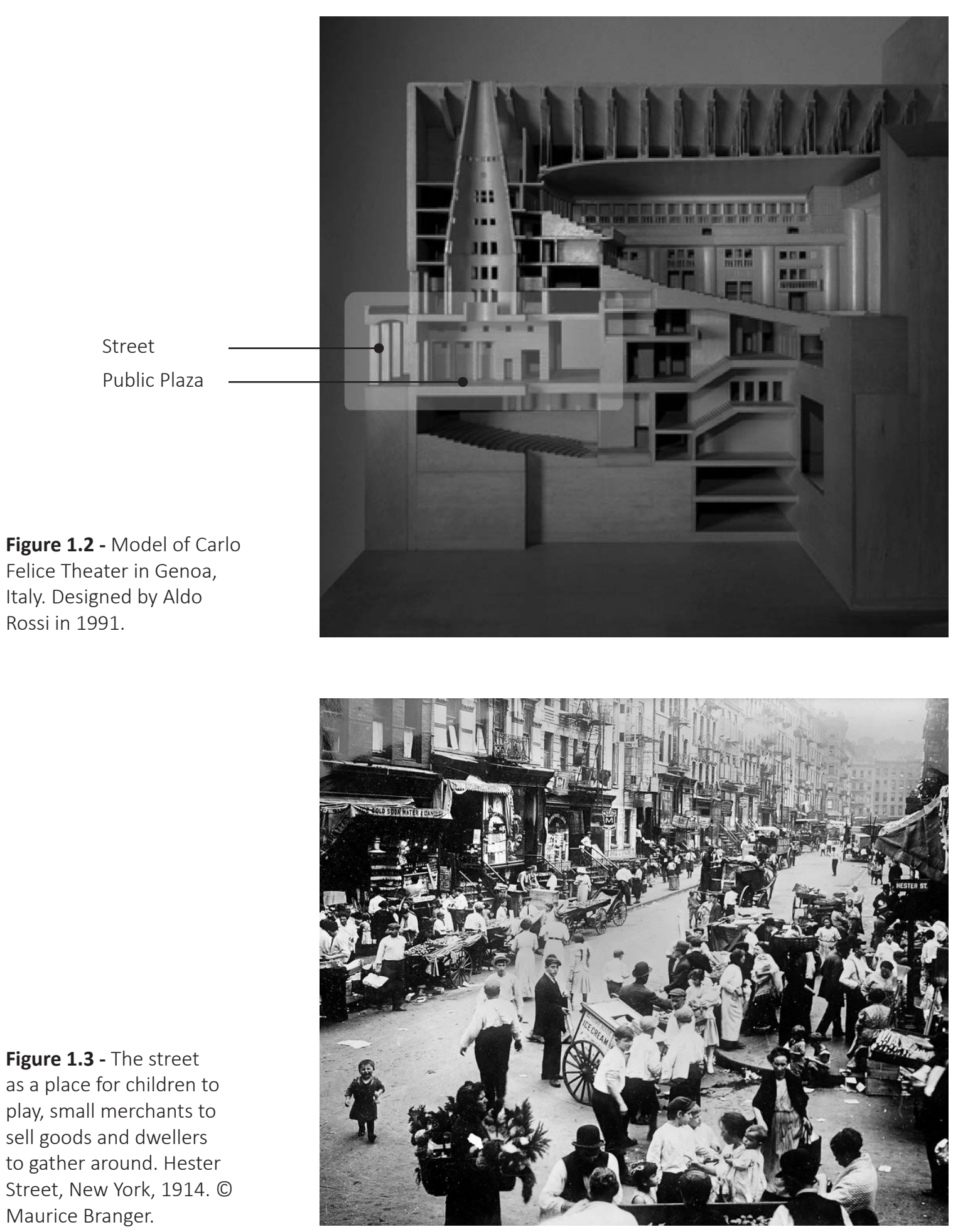

As a series of spaces weaved together, streets should be able to provide a continuous public space for people. With the New Official Plan, the City of Ottawa recognizes the need to invest in streets and sidewalks to reshape and reform the cityscape through urban design. To accomplish this, the city proposes two policies. Policy 2.2.4.1 encourages the development of 15-minute neighbourhoods, which act as "complete communities that support active transportation and transit, reduce car dependency and enable people to live car-light or car-free." ${ }^{17}$ Policy 4.6 .3 promotes the development of living streets, which refer to the "temporary reallocation of street space from primarily serving vehicles to serving people." ${ }^{\prime 18}$ These two policies can ensure a future for public space to emerge in city streets. However, the New Official Plan does not outline implementation steps or an updated city budget to allow for these changes. In the Ottawa Citizen's article, "Dresden: Ottawa's official plan is bold. Will city council be bold too?", architect Toon Dresden points out that "creating the built environment is a political act."19 As a city that often struggles with slow bureaucratic processes, the changes this city needs cannot be left to be undertaken by the government alone. 


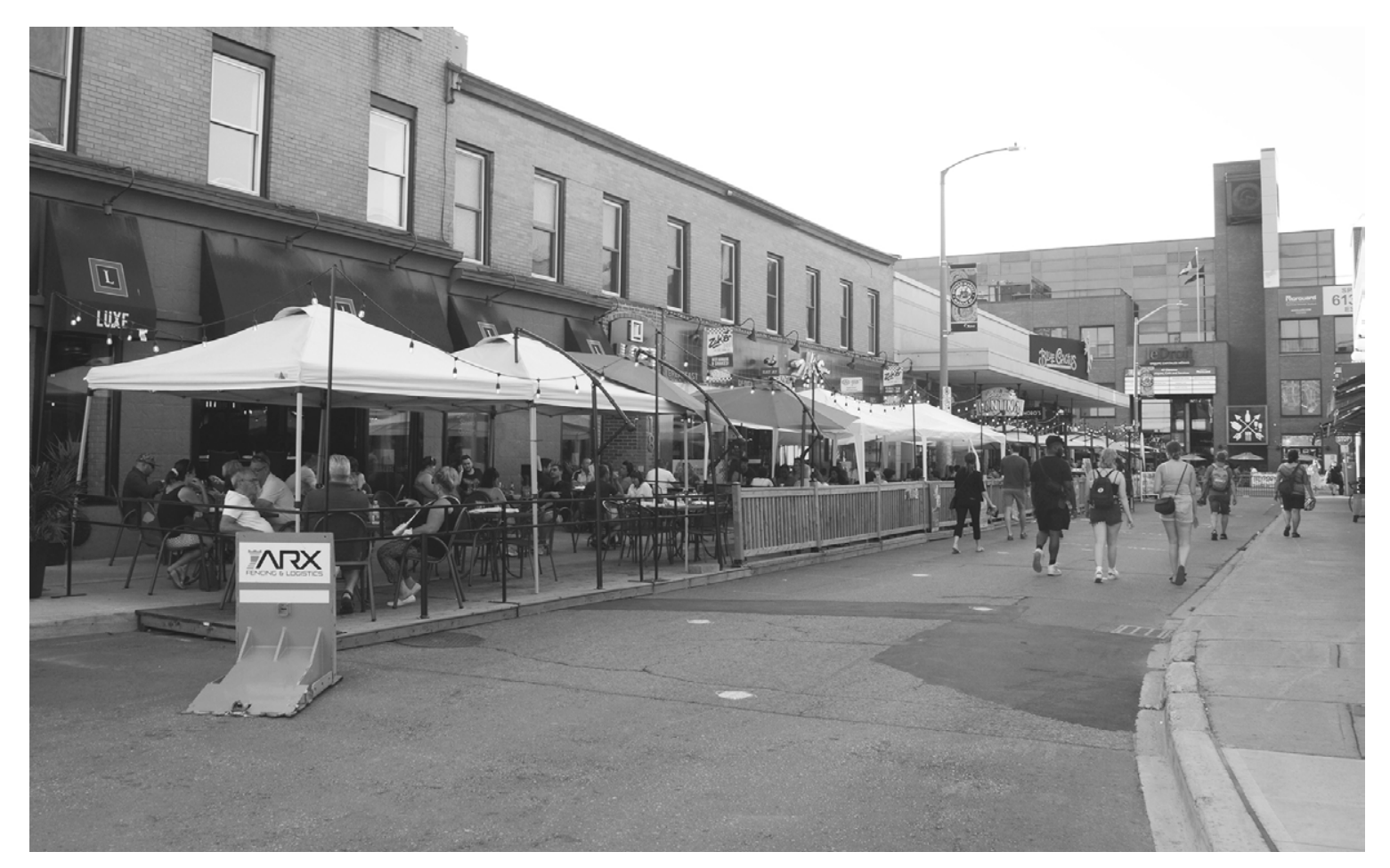

\subsection{THE STREET IN THE TIME OF COVID}

Figure 1.4 - A summer day

in Byward Market Squere,

during the coviD-19

pandemic, Ottawa, 2020

(c) Photographed by the

author.

Throughout the Covid-19 pandemic, the importance of public health and personal distancing in our everyday lives became the priority. Provincial authorities asked people to transfer their work and leisure lives inside. ${ }^{20}$ As private businesses and vehicles withdrew from the streets, a once buried public space emerged. Many cities across Canada opted to open-up portions of their streets and allowed people to access public space while complying with social distancing restrictions. ${ }^{21}$ Ottawa was a little late in the game, as the municipality feared that opening-up streets to pedestrians would lead to overcrowding. ${ }^{22}$ Eventually, other public entities worked towards granting more space for people in the city: the NCC closed the Queen Elizabeth Driveway to vehicular traffic, 
and Westboro's councillor Jeff Leiper blocked off a stretch of Byron Avenue. ${ }^{23}$ After being confined to their homes for weeks, these tactical transformations encouraged people to walk around the block, enjoy the sun and safely talk to neighbours six feet away.

For a while, opening-up streets to the public while closing them to traffic allowed people to reappropriate the public sphere. However, the second phase of the lockdown revealed structures of power and invisible boundaries that encompass the public realm. The partial reopening of cities allowed private enterprises like restaurants to expand their dining rooms onto the street. Although it is crucial to recognize that the economic crisis would have put restaurants and other shops out of business, the total occupation of the public realm by the private sector has unfortunate consequences for city-users. For instance, in Ottawa, patios taking over the ByWard Market Square's sidewalk created a barrier of disconnection between public and the buildings of the urban fabric (figure 1.4). The sidewalk is part of the public realm; nevertheless, private entities enclosed the area and built fortified enclaves to open-up space for paying customers only. The same policies that previously helped people reinhabit the public realm suddenly restricted the same space for private consumption.

As businesses move onto the street, they tend to set physical barriers and behavioural regulations that restrict city-users' freedom of movement and diversity of use. In this particular example, the street's section intended for pedestrian movement is too narrow for activities other than circulation to occur (figure 1.5); to stop for a moment or gather with friends, a person along this path must pay to the businesses lined-up along the sidewalk for the experience. In the future, city leaders must think of a more balanced and inclusive approach for private entities and the public to share the sidewalk. For example, an option can be for municipalities to set-up areas for open tables that are accessible to all, including the surrounding restaurants' customers.

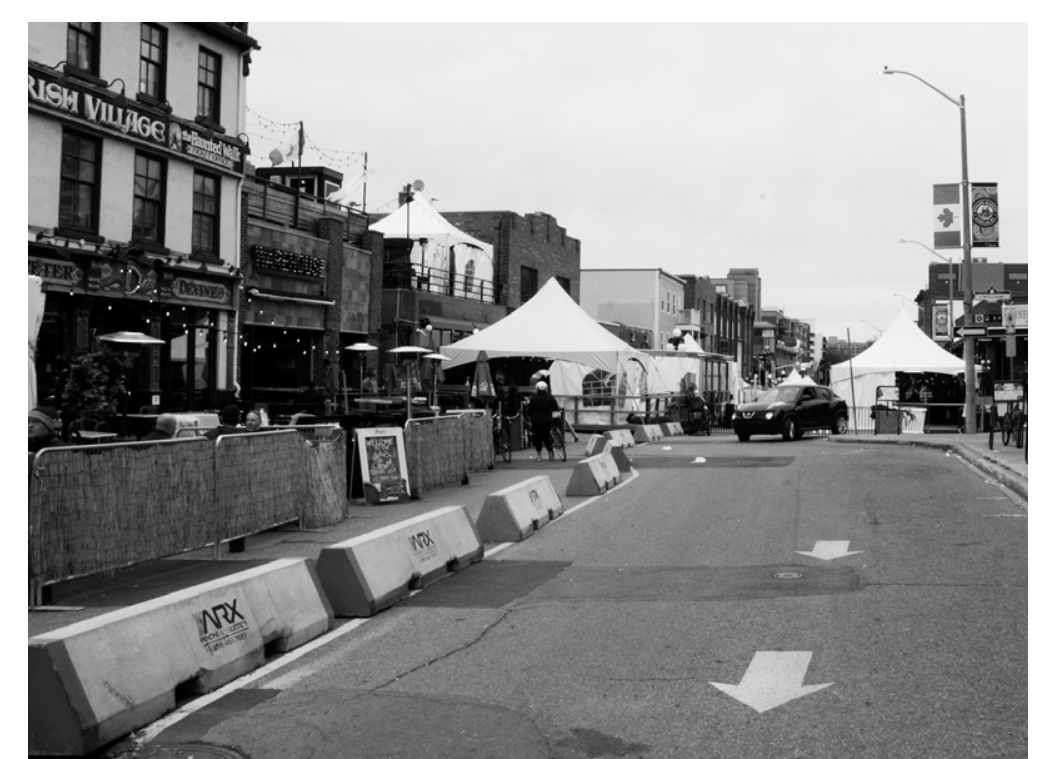

Figure 1.5 - A fall day in Clarence Street and Byward Market Square, during the COVID-19 pandemic, Ottawa, 2020. (c) Photographed by the author. 


\section{A WALK ALONG THE STREET}

SITE ANALYSIS 
"The most ancient traces of human life on Earth are paths. Networks of paths came long before buildings and urban blocks, marking the patterns of mobility and reflecting economy of human energy: walking. The street as a space resulted from connecting these patterns of human mobility to the human activities in buildings." ${ }^{24}$

\subsection{THE STREET}

PUBLIC LIFE ON BANK STREET

In this quote, Gehl Architects' creative director and author of the book Soft City, David Sim, briefly describes the evolution of the street into city life. As connectors of activities, streets can bring people together and enable them to share portions of their private life in the public realm. However, in Ottawa, there is often not enough space available for people to extend life onto the street, as most spaces are privately owned and commercial in nature. The following chapter looks at this urban pattern and its consequences on Bank Street.

Bank Street emerges at the northernmost part of Ottawa, a few steps west of the Parliament, perpendicular to Wellington 
Street, within the Centertown neighbourhood. Life on the street unfolds among a white masonry backdrop on one side and a dark steel facade with an open plaza at ground level on the other. The long artery represents a significant thread in the city's network, crossing vital streets and neighbourhoods along its path. From Centertown to Old Ottawa South, Bank Street condenses multiple connecting points attracting diverse groups of people (ethnic, socioeconomic, age) to travel along the street. While walking down Bank Street, a dweller will find a pedestrian promenade that bridges walkers to various downtown office buildings, Sparks Street. Travelling down south, there is Somerset Street; along this path lives Ottawa's Chinatown and a section of Little Italy. Further down, Bank Street morphs into two sets of bridges. One crosses over the Rideau Canal and the other over the Rideau River. From here, the street connects to bike and pedestrian pathways for people to contemplate and enjoy a landscape of greenery and water over the changing seasons.

This long artery can connect city-users with many places in the city, attracting a diverse population to the street. In Soft City Sim states that diversity and concentration are two necessary conditions for livable urban spaces. ${ }^{25}$ Hence Bank Street in
Ottawa could be an ideal location for a public life continuum to emerge. In Death and Life of Great American Cities, Jacobs lists four indispensable conditions to generate diversity: concentration, small blocks, aged buildings, and mix-uses and services. ${ }^{26}$ From the Centertown neighbourhood to Old Ottawa South, Bank Street meets three out of four of these conditions. Superficially, it might seem that Bank Street hosts mix-uses and services like schools, residential spaces, office buildings, etc. However, BankStreet hosts mainly commercial services at ground level, and these spaces are not publicly accessible. As mentioned in section 1.1 Public Life Along the Street, commercial services are categorized as prescribed activities. In Bank Street, $84 \%$ of the space at ground level is bounded to prescribed activities: $47 \%$ retail storefronts, 9\% miscellaneous spaces (such as institutions and religious buildings) and $29 \%$ vehicular transit. That leaves only $16 \%$ of the street for public use, including pedestrian circulation and the emergence of unprescribed social activities. 


\subsection{THE NEIGHBOURHOODS}

CENTERTOWN, THE GLEBE AND OLD OTTAWA SOUTH

The great length of Bank street allows over its $70 \mathrm{~km}$ development -making it the longest street in Ottawa- for a street life's study conducted through the lenses of three different neighbourhoods closest to downtown: Centertown, The Glebe and Old Ottawa South. Along these three neighbourhoods, Bank Street acts as a connecting artery to other areas of the city (figure 2.1). 


\section{CENTERTOWN}

Centertown is the heart of Ottawa's downtown (figure 2.2). Over the years, the area has experienced residential growth tied to work proximity and walkability advantages. ${ }^{27}$ Making adults (25-64 years old) represent $68.8 \%$ of the area's population. ${ }^{28}$ Compared to the other neighbourhoods in this study, Centertown has the highest percentage of people living alone, 39.5\%. ${ }^{29}$ However, along Bank Street, space for social activities is minimal. The streetscape comprises of some office and apartment towers, two storey-buildings and a few religious entities.

Most buildings use the ground floor for commercial purposes, marking the edge between private and public. 
Figure 2.3 - Community street garden outside the Centertown United Church, Ottawa, 2020. (c) Photographed by the

Figure 2.4 - Empty lot enclosed by a metal fence between 136 and 152 Bank Street, Ottawa, 2020 (c) Photographed by the author
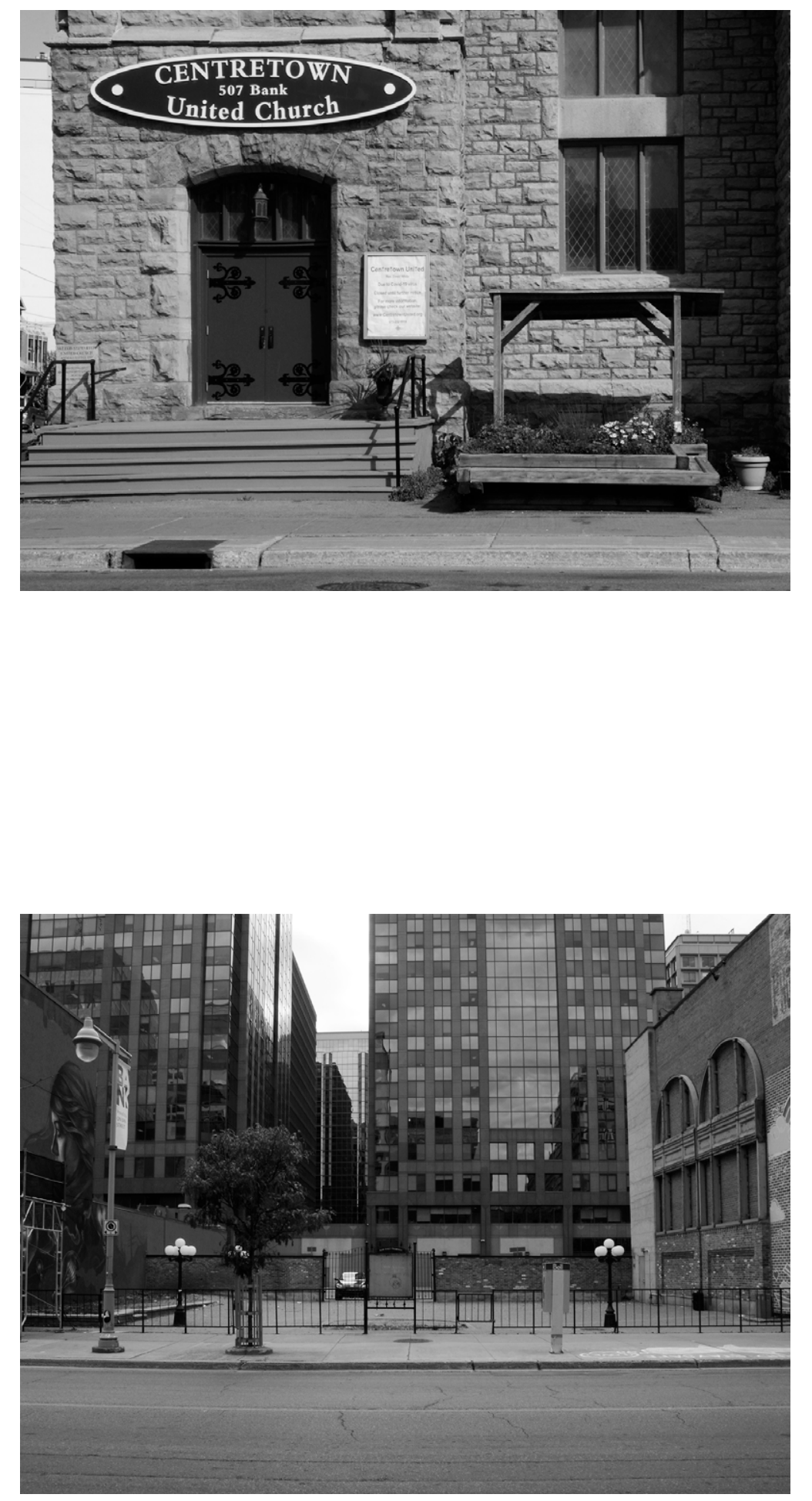

Along the twenty blocks that comprise this section of Bank Street, there are only two areas designed for public gatherings: the Bank of Canada Museum's plaza and a community street garden outside the Centertown United Church (figure 2.3). Other open spaces are dormant gaps between structures or empty street corners like the empty lot enclosed by a metal fence between 136 and 152 Bank Street and L'Esplanade building's empty corner (figure 2.4). Aside from the Bank of Canada and the Centertown United Church's garden, public infrastructure mainly consists of about ten benches along the sidewalk over the 20 block span. 


\section{THE GLEBE}

Once considered a rural, suburban area at the city's limits, ${ }^{30}$ the Glebe flourished to be one of Ottawa's vibrant neighbourhoods (figure 2.5). Today, families with children and youth make up most of the area's population; 55.5\% adults (25-64 years old) and 28.2\% of children and youth (0-24 years old). However, the eclectic coffee houses, office spaces and unique local shops attract many young professionals to the street. While in Centertown, Bank Street is one of many commercial spaces. In the Glebe, Bank Street functions as the main commercial strip. Buildings are primarily low-rise with commercial ground floors, except for some mid-rise and high-rise apartment buildings around Lansdown. 
Figure 2.6 - The

Patterson's Creek Park

intersection opens-up

views of the park, Ottawa,

2020. (c) Photographed by

the author.

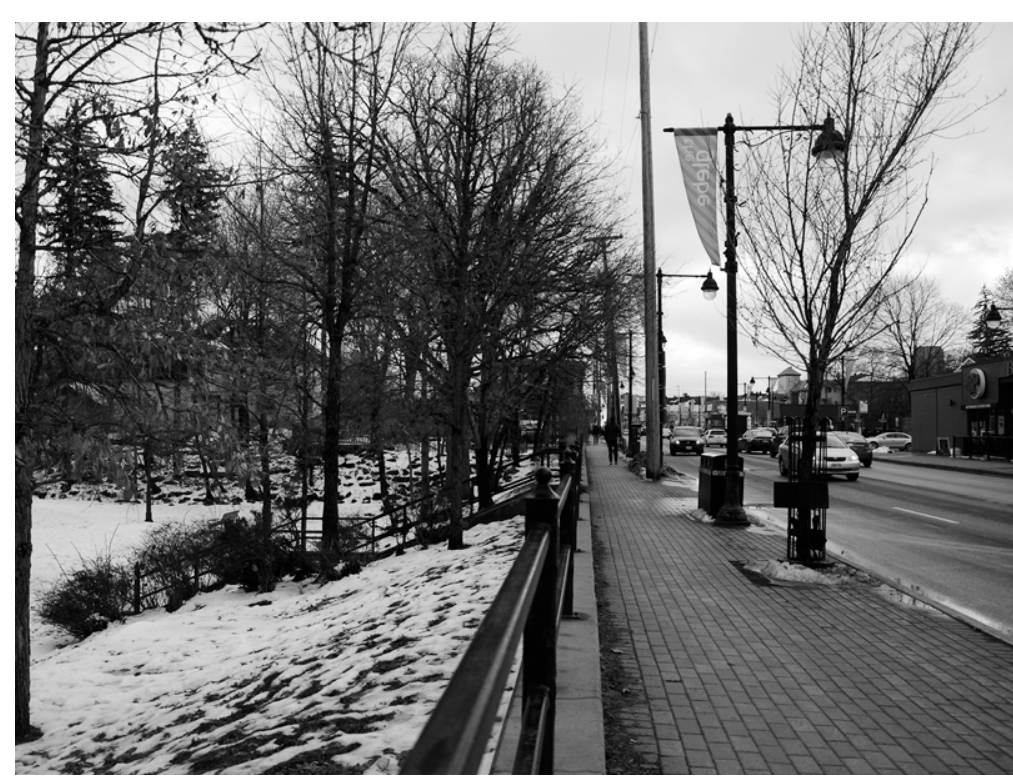

The blocks' edges are sometimes more spread apart than Centertown, which sometimes allows for open spaces that people can inhabit. For instance, The Patterson's Creek Park intersection opens-up views of the park, which provides a visual break from the storefront (figure 2.6). However, other smaller gaps like alleyways are not as engaging as they are often used as parking spaces (figure 2.7). Since this section of Bank Street counts with sixteen other parking lots and street parking space, some gaps could be used for public purposes.

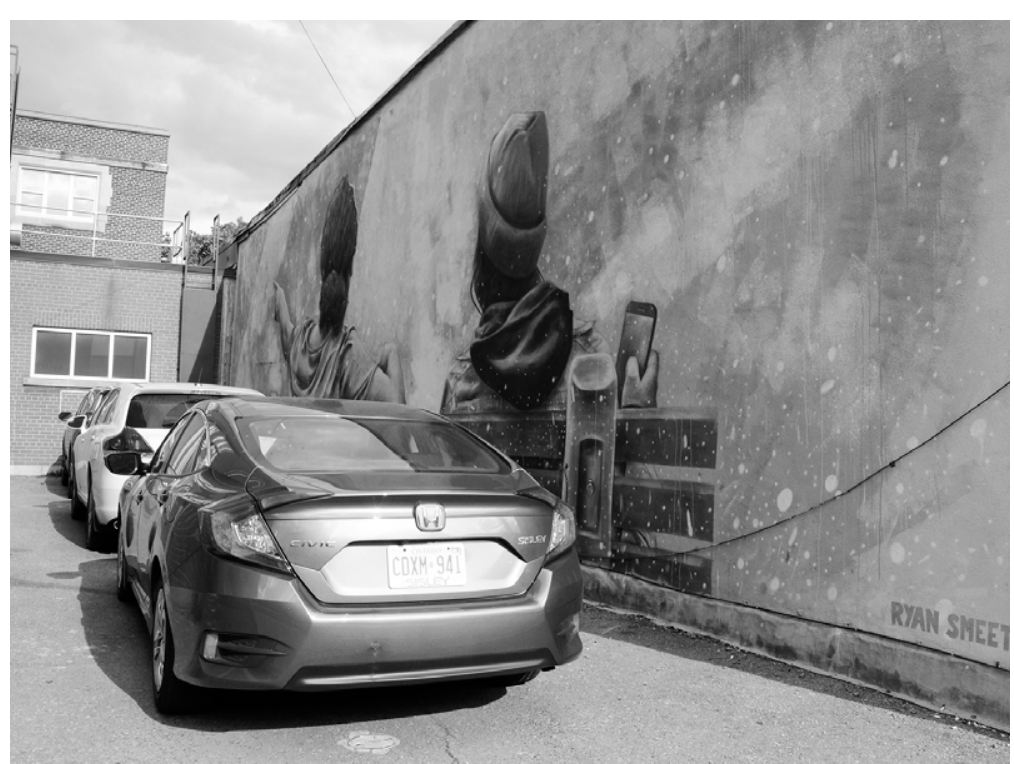




\section{OLD OTTAWA SOUTH}

Bundled between the Rideau River and Rideau Canal lies Old Ottawa South (figure 2.8). This area is home to many young families, with children (0-14 years old) and youth (14-24 years old) making up a large part of the population, 19.1\% and $15.6 \%$ respectively. ${ }^{31}$ This neighbourhood's morphology is similar to that of the Glebe, with a traditional main street occupied by two-storey buildings and residential houses spread within the surrounding areas.

However, Old Ottawa South differs from the previous two neighbourhoods, as storefronts do not always define Bank Street's edge. Buildings are spread apart from each other, leaving large empty gaps along the street (figure 2.9). About 
Figure 2.9 - Storefront at 1063 Bank Street, Ottawa,
2020. @ Photographed by the author

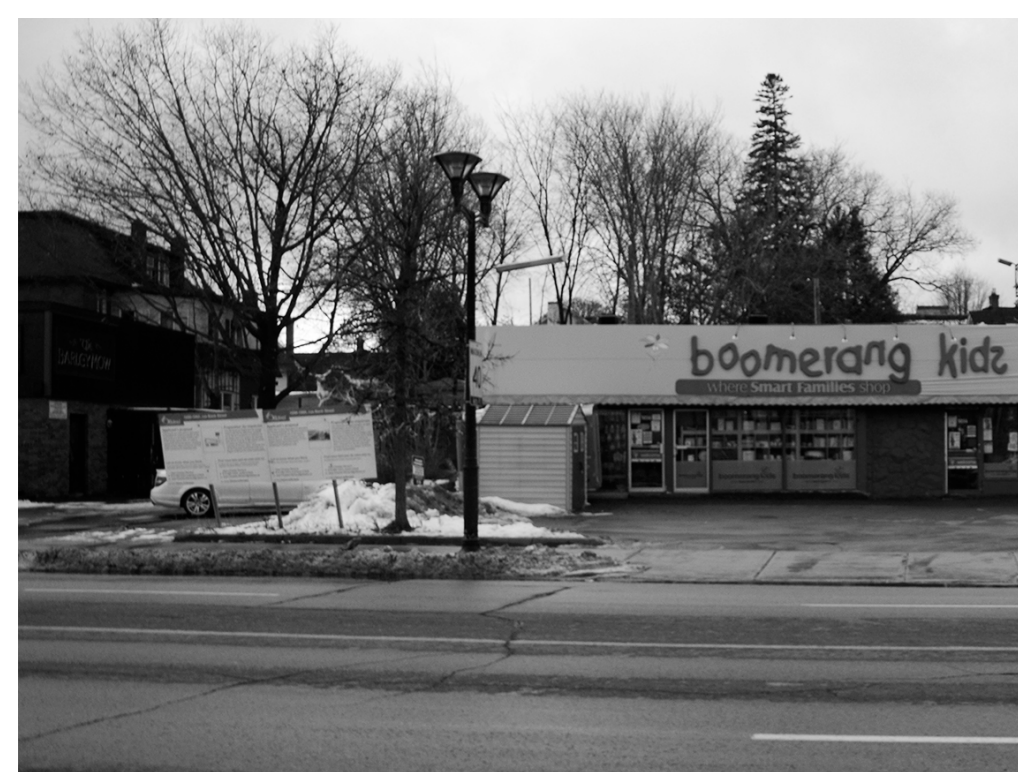

Figure 2.10 - Open corner between Belmont Street and Bank, where the

Sri Chinmoy Meditatio

Centre has placed a

cluster of benches and

planters around a small

monument, Ottawa, 2020

(C) Photographed by the

author.

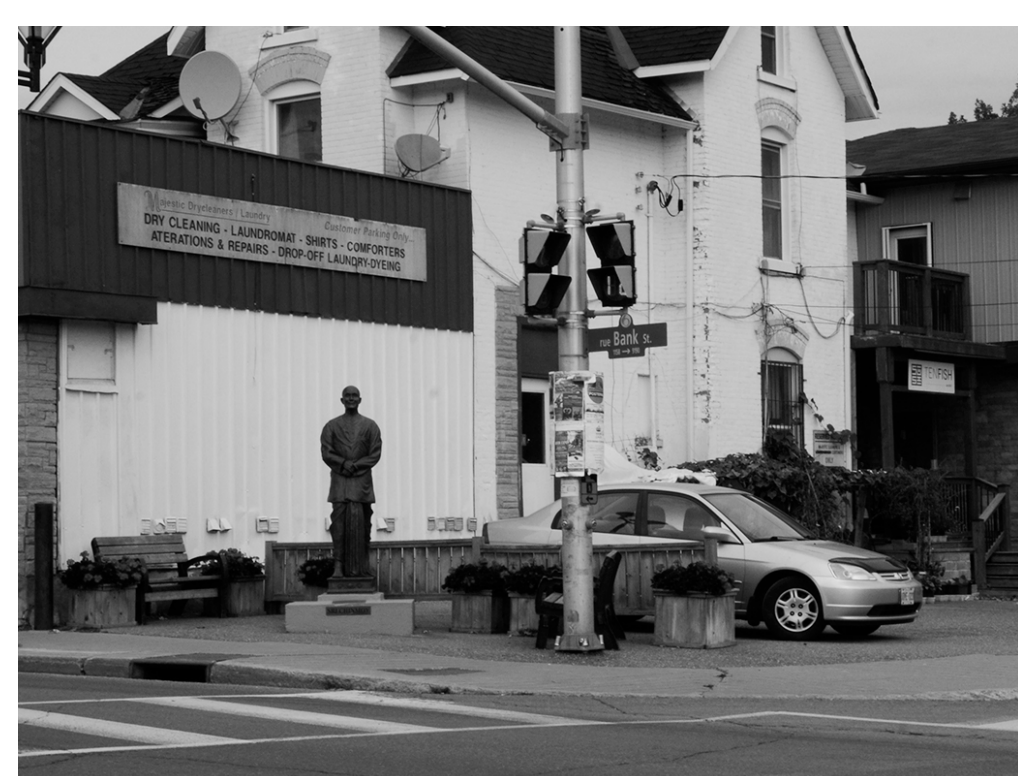

twenty of these gaps are used as parking lots. A characteristic that makes this path less engaging to walkers. Among the ten blocks that comprise this section of Bank Street, there are only two open spaces for public use. One is an open corner between Belmont and Bank Street, where the Sri Chinmoy Meditation Centre has placed a cluster of benches and planters around a small monument (figure 2.10). The other open space is a gathering area in the park at the edge of the Rideau River. Besides these two spots, other public infrastructure on the street consists of six benches spread along the sidewalk. 
Figure 2.11 - Bench on the intersection Bank Street and Waverley Street West, Ottawa, 2020.

(c) Photographed by the

author.

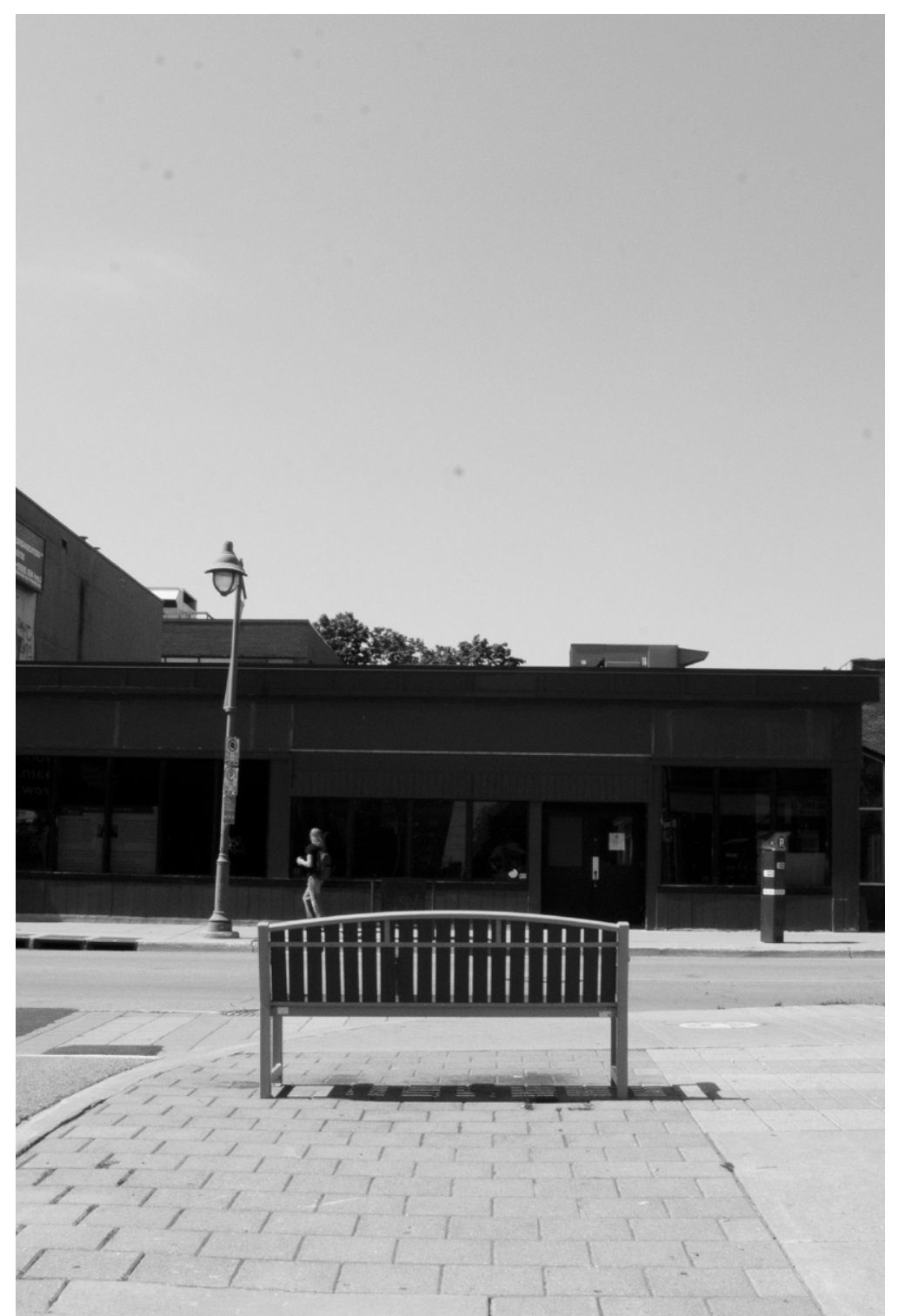

\subsection{UNPLEASANT DESIGN}

While Bank Street's functionality invites diversity, it lacks the infrastructure to host it. For public life to unfold, it is not enough to enable spaces for movement; favourable conditions for lingering must also exist for optional and social activities to evolve. ${ }^{32}$ In this study, the three neighbourhoods have high walkability scores: Centertown at 94.3 , the Glebe at 85.8 and Old Ottawa South at 81.3.33 The Ottawa Neighborhood study website describes a walk score to "measures walkability on a scale from 0-100 based on walking routes to destinations such as grocery stores, schools, parks, restaurants, and retail." ${ }^{\prime 34}$ However, the score fails to address the quality of the walkable environment. The neighbourhoods' analysis above shows that open spaces in 
Bank Street with pleasant conditions for people to stop and linger are minimal.

Besides the few gardens outside of religious institutions or parks intersecting with Bank Street, public infrastructure consists of randomly set-up benches. Gehl notes in Life Between Buildings that people tend to seek spaces along spatial boundaries to stand or sit. ${ }^{35}$ In Bank Street, sidewalks are often tight, so benches are mostly found on street corners with no edge to ground them (figure 2.11). The benches ar bolted to the pavement, so it is impossible to rearrange their configuration and have a face-to-face conversation with another person comfortably. They are also designed with an armrest in the center to prevent a person from lying down. The benches' hostile design contributes to an anti-human narrative in the city. In an interview with radio producer Roman Mars, architect and writer Selena Savic defines hostile or unpleasant design as a social control technique where an object's unique features restrict users' behaviours. ${ }^{36}$ Artist Sarah Ross' project Archisuits captures this term with a suit designed to fit a street bench's structure (figure 2.6). ${ }^{37}$ The public realm is a shared space that requires constant negotiations and adaptations to meet city-users' various needs. However, unpleasant and even hostile designs stand on our streets, immutable, untouchable, unchangeable by most. The scarce design consideration given to environmental qualities along the street has generated an obsolete public space pattern in the urban fabric.

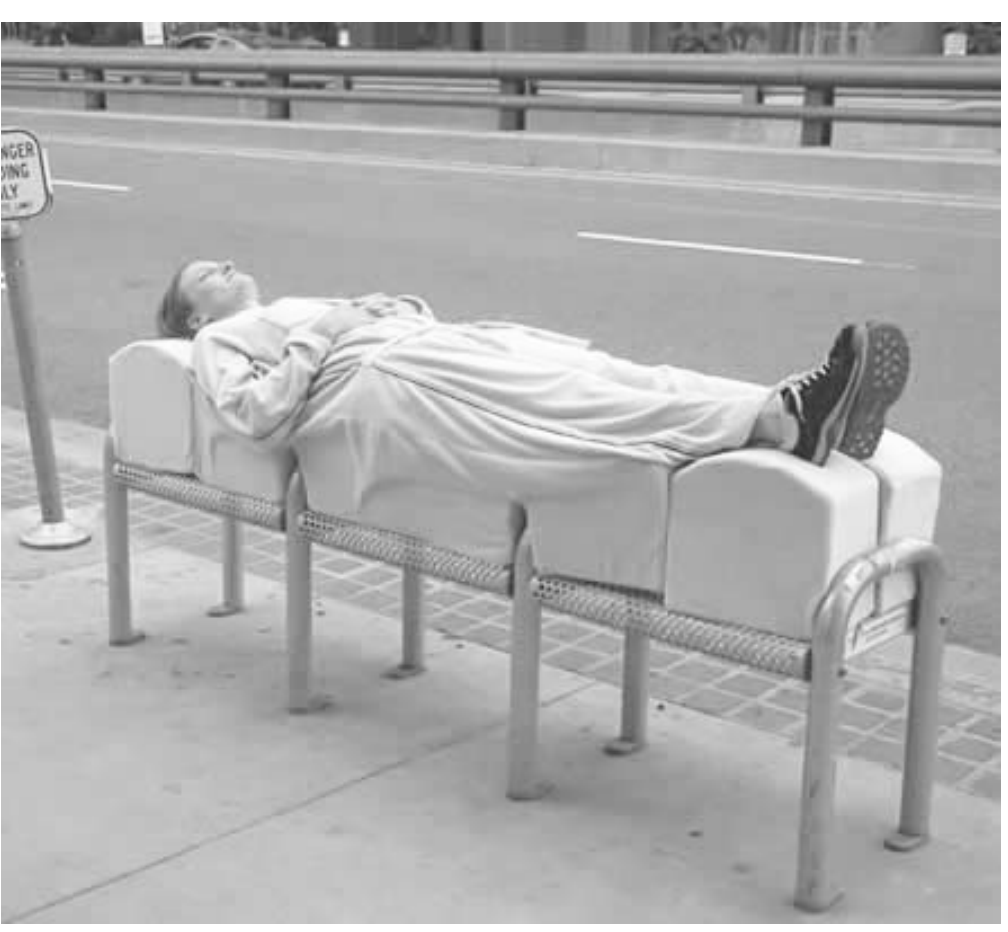

figure 2.12 - Sarah Ross' project Archisuits (2005). The project is a critique against urban spaces and their inhospitality to the human body, the suite includes the structure's the wearer to fit into the system designed to deny them" "38 LOs Angeles, USA 2005. @ Sarah Ross. 


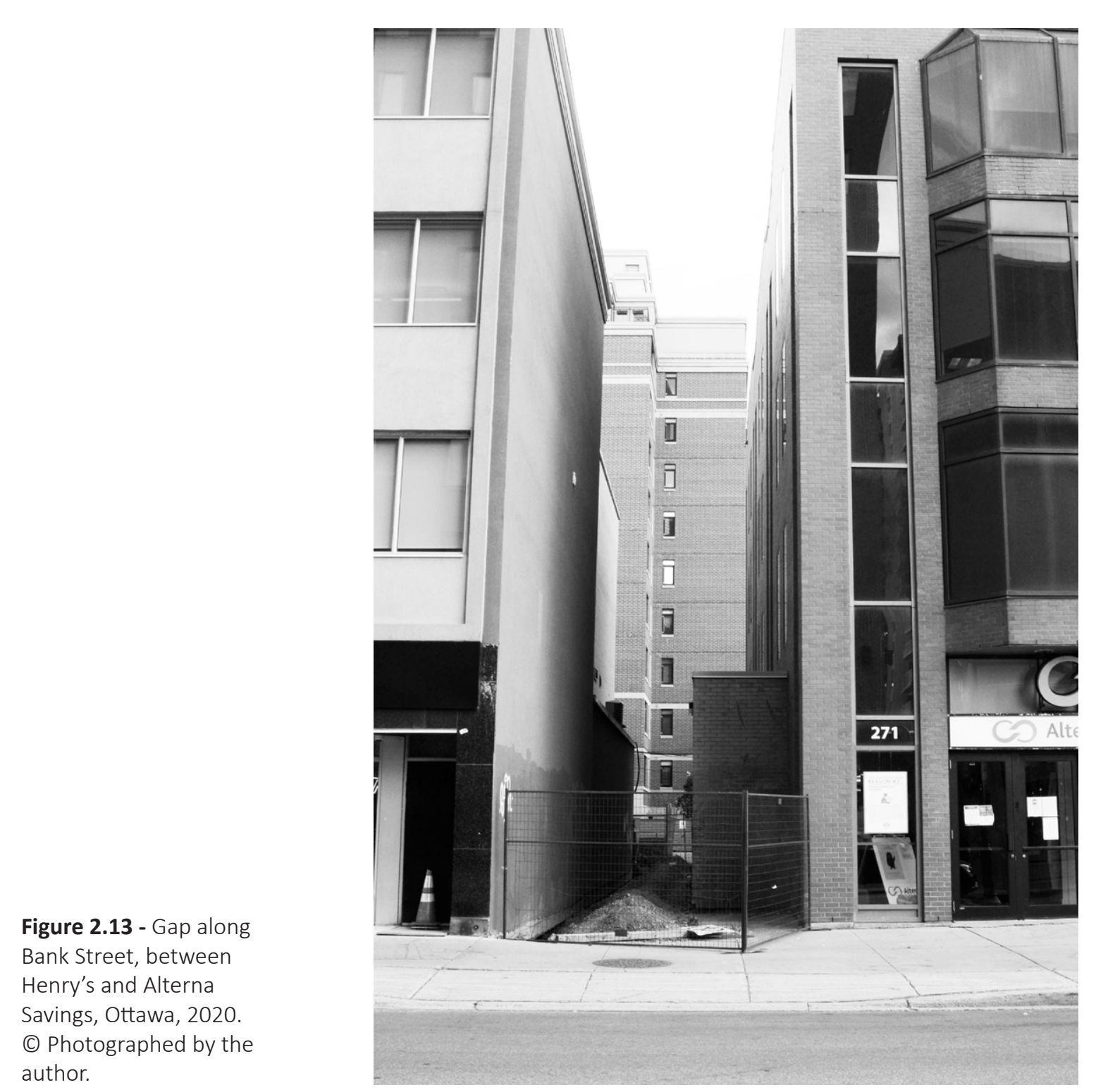

\subsection{THE GAP}

While Bank St. might lack pleasant conditions for people to stop and linger, the street comprises a variety of open spaces with undiscovered potential for publicness. There are voids between buildings or along facades that go unnoticed on our daily passing; leftover spaces missing a function or wasting away as surface parking lots; and oddly shaped pockets lacking adequate infrastructure for people to inhabit. These gaps are dormant spaces that break the continuity of the public realm.

Nevertheless, the lack of defined edges regarding both functionality and physical barriers welcomes 'looseness.' Franck and Stevens defines 'loose space' as a by-product 
of street life, the different ways city-users discover and appropriate public space. ${ }^{39}$ 'Looseness' allows for boundaries to be redrafted and new uses reimagined, providing opportunities for different forms of interactions with and within the urban fabric

Four gap typologies along Bank Street are identified in this study: the corner, the storefront, the alley and the surface parking lot. In Part 3, each gap is analyzed and reframed to explore the possibilities of 'loose space.'

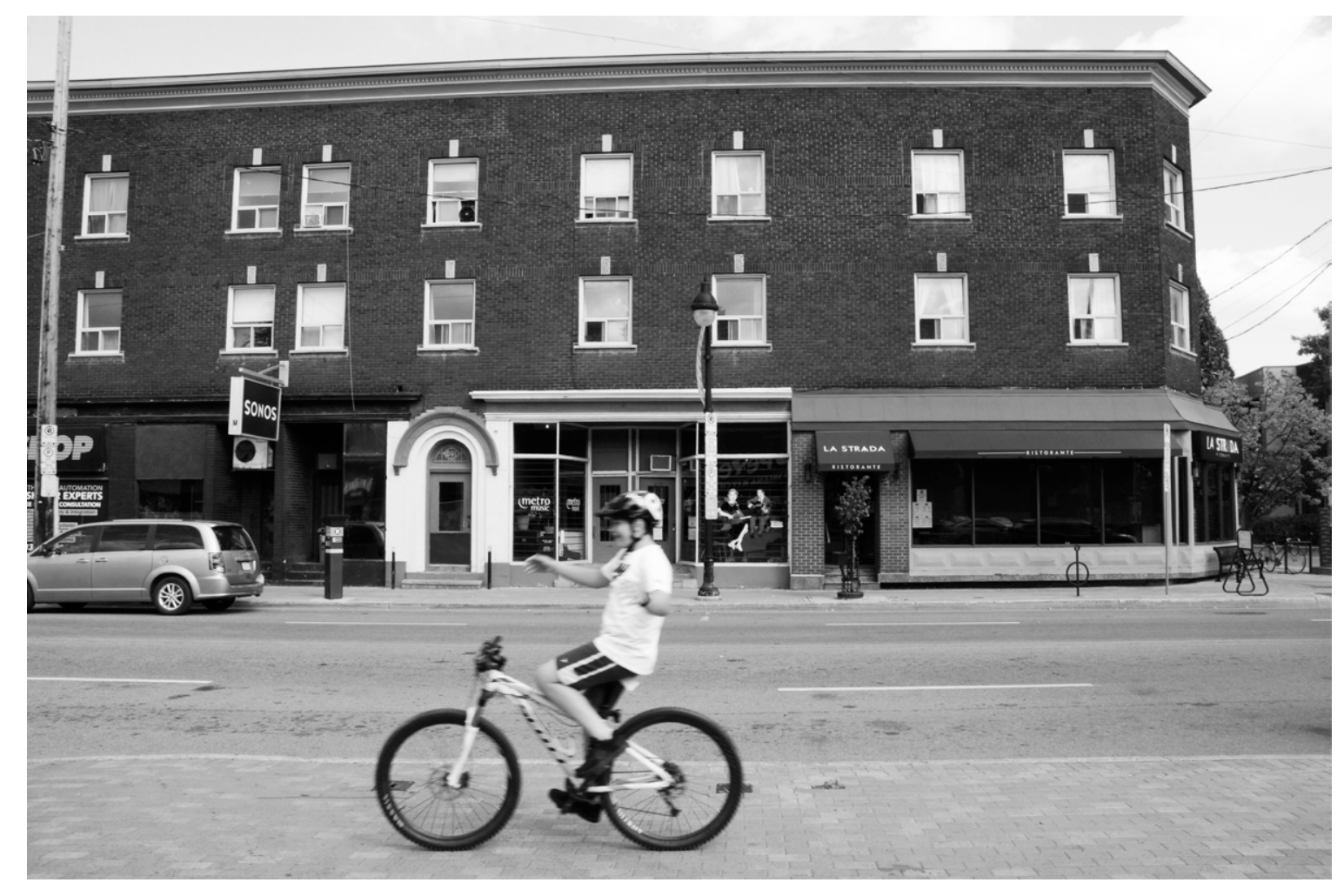

Figure 2.14 - For this boy the sidewalk along Bank Street can suddenly turn 2020. the author. 

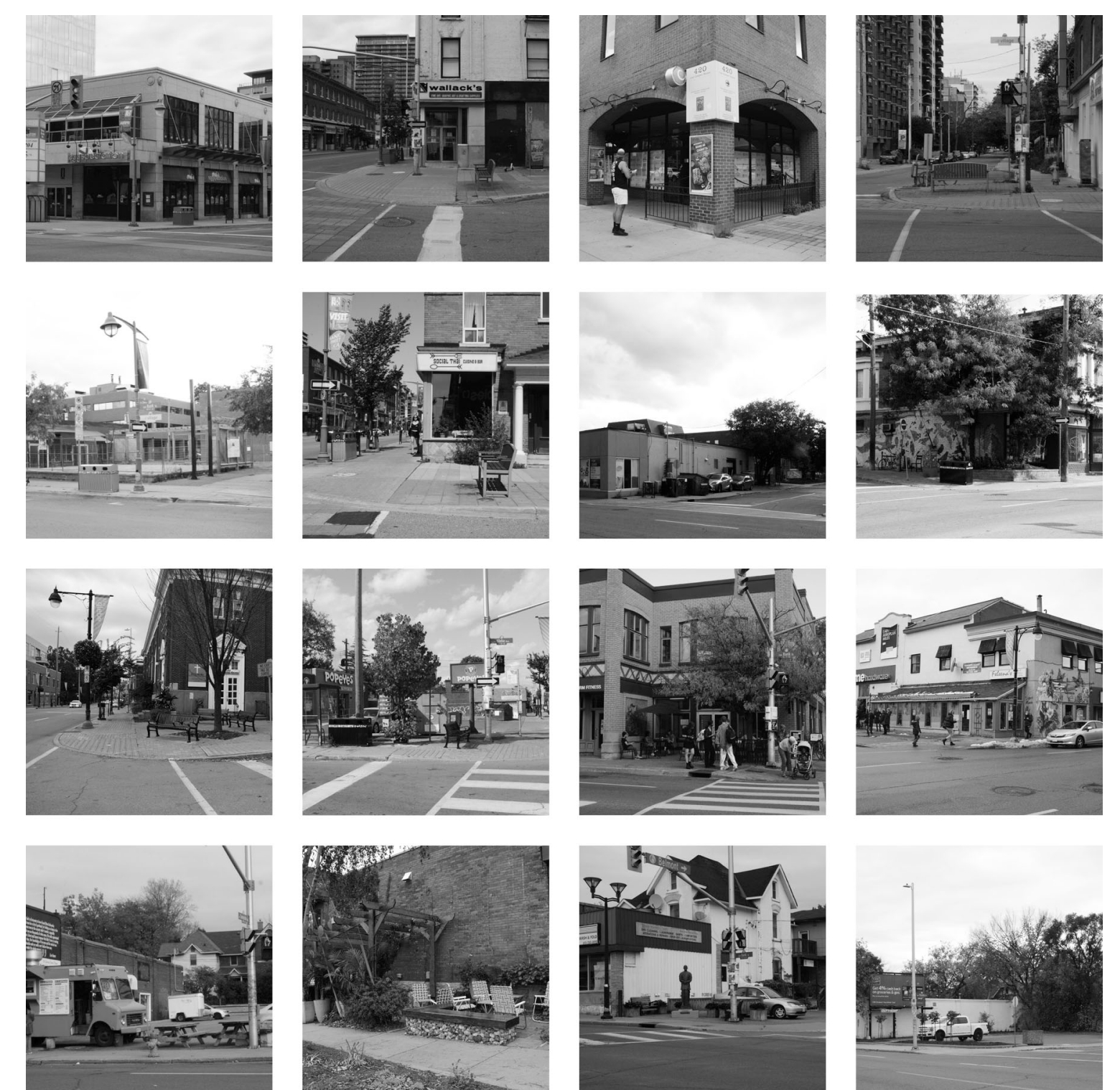

\section{CORNER}

On Bank Street, some corners' sidewalks extend onto the roadbed or contain setbacks that provide additional pedestrian space. But rather than infrastructure for people to use, this extra space is populated with unpleasant benches, private patios, or empty parking lots. Within the block, corners mark the meeting point of two edges. People walking on the street tend to agglomerate in these areas as they converge in-between intersections or wait to cross streets. As suggested by David Sims in Soft Space, these urban features, are distinct enough to function as an orientation point or a designated meeting zone. ${ }^{40}$ These characteristics make corners ideal locations for community gatherings, where people congregate, share a meal, or watch a local performance. 
Figure 2.16 - Collection of storefronts along Ban Street, Ottawa, 2020. hed by the
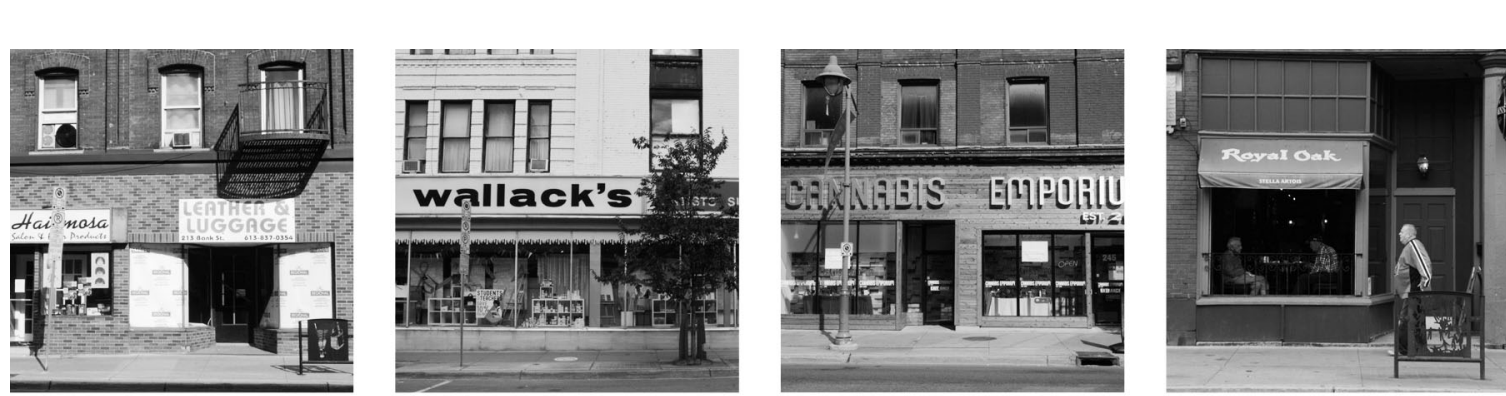

\section{STOREFRONT}
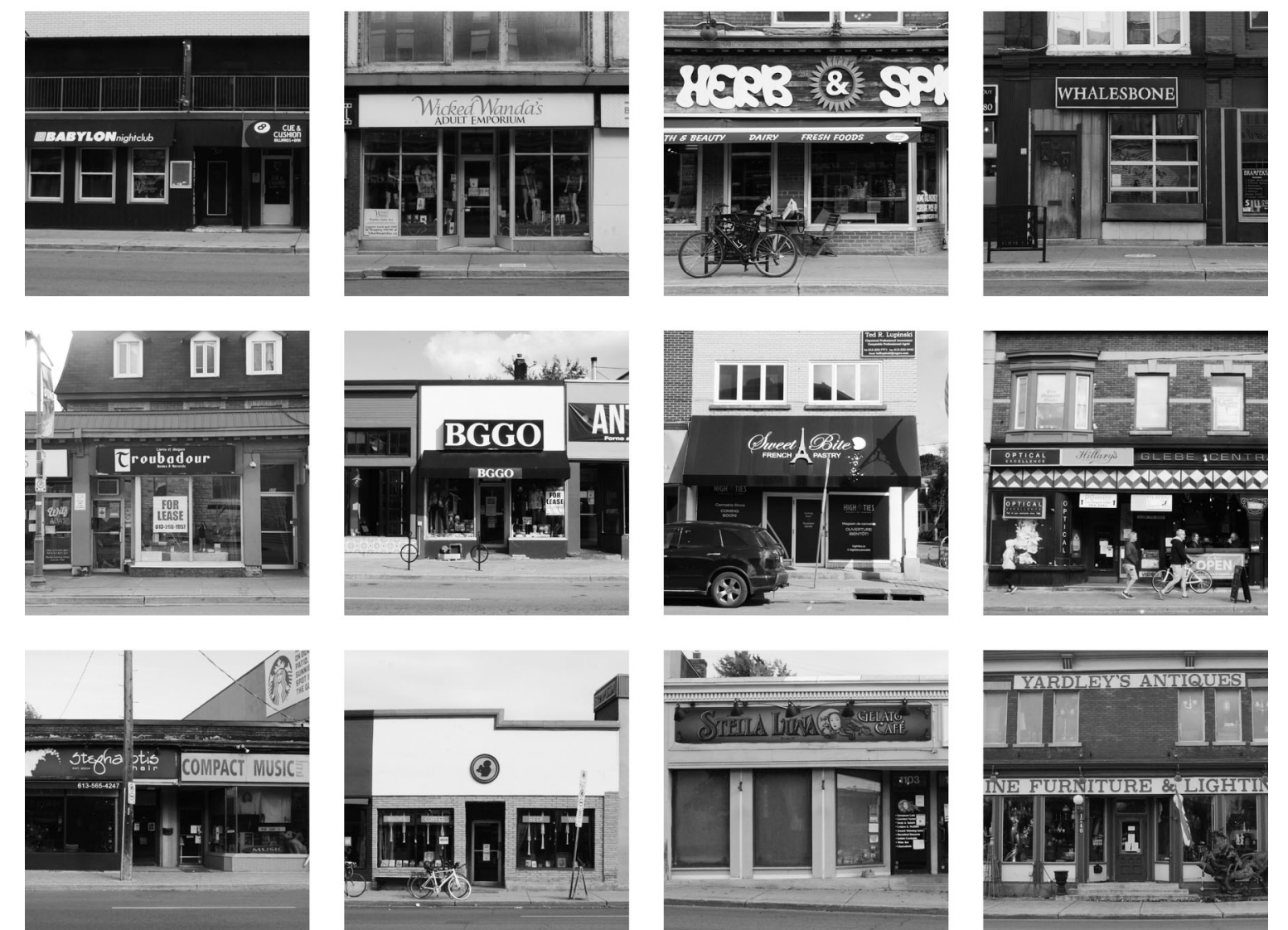

Storefronts align along the sidewalk's edge, functioning as a two-dimensional barrier dividing the private and public. However, by occupying a prime piece of real estate for its accessibility to the public, storefronts could have a more interactive dialogue with the urbanscape. The façade design of the 'Storefront' for Art and Architecture (1993), by Steven Holl in New York, can serve as a precedent. ${ }^{41}$ The openings and incisions on the façade achieve a degree of permeability between the commercial and the commons. Designers and store owners can also rethink the storefront's display section. Instead of showcasing inanimate objects, storefronts can display activities along with the products. For instance, a furniture store could showcase office furniture while providing a start-up with a meeting area. 

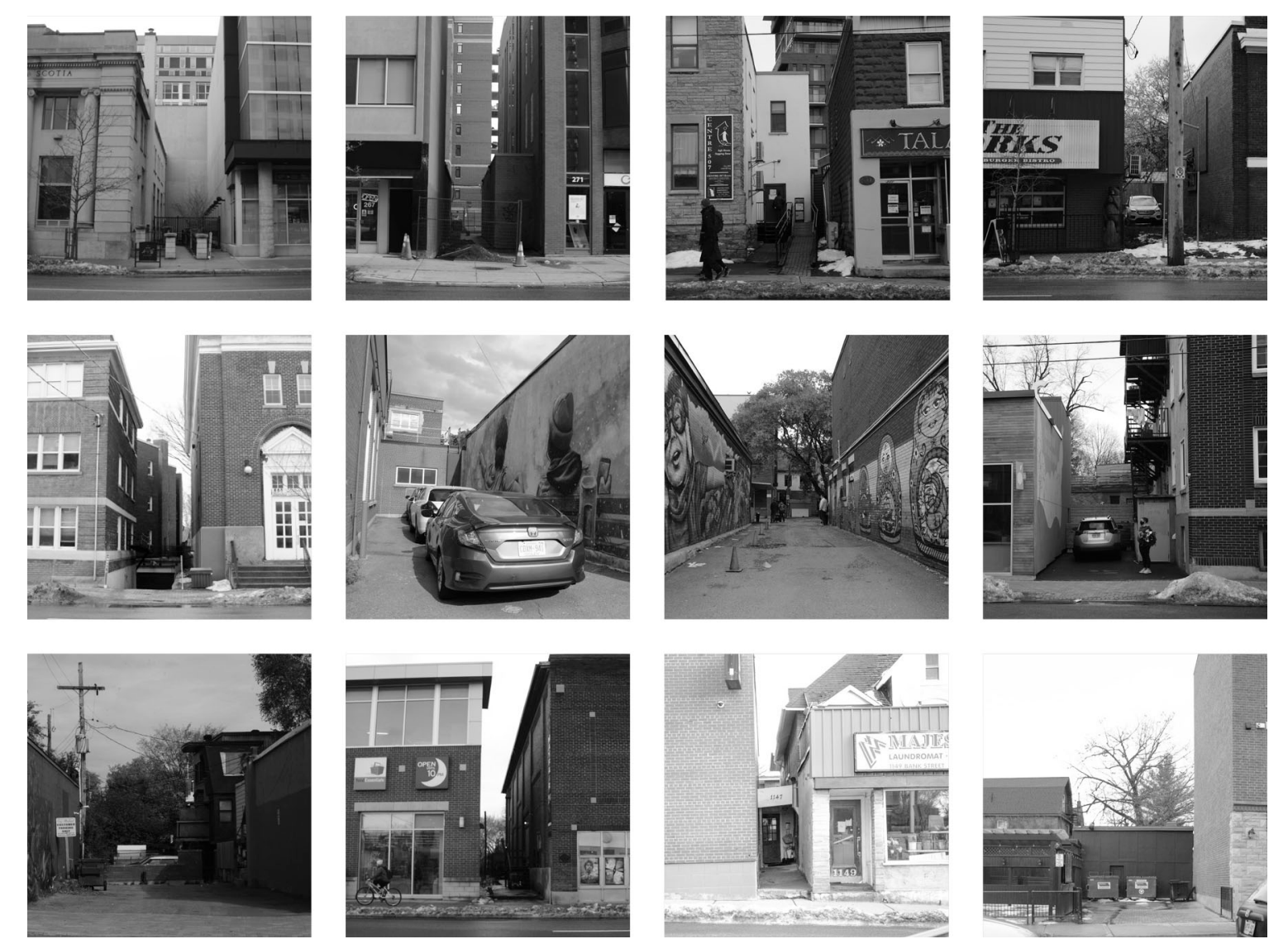

\section{ALLEY}

A narrow passage carved within the block, the alley is often misused as a parking spot or a dumpster's keeper. Two parallel walls often shape this gap, enhancing the spatial linearity while limiting side-to-side movement. Alleys behave as secret passageways people travel through to reach other streets and invisible neighbourhoods that hide behind the main avenue. However, more peculiar passageways allow for upward movement, as they accommodate the emergency stairways for side buildings. Along alleys, forward movement is often public, but upward movement is reserved only for the building's residents. Nevertheless, as passageways, alleys can be reimagined for all dwellers to move between levels, creating a new dimension for the public realm. 
Figure 2.18 - Collection of surface parking lots along Bank Street, Ottawa, 2020

author.
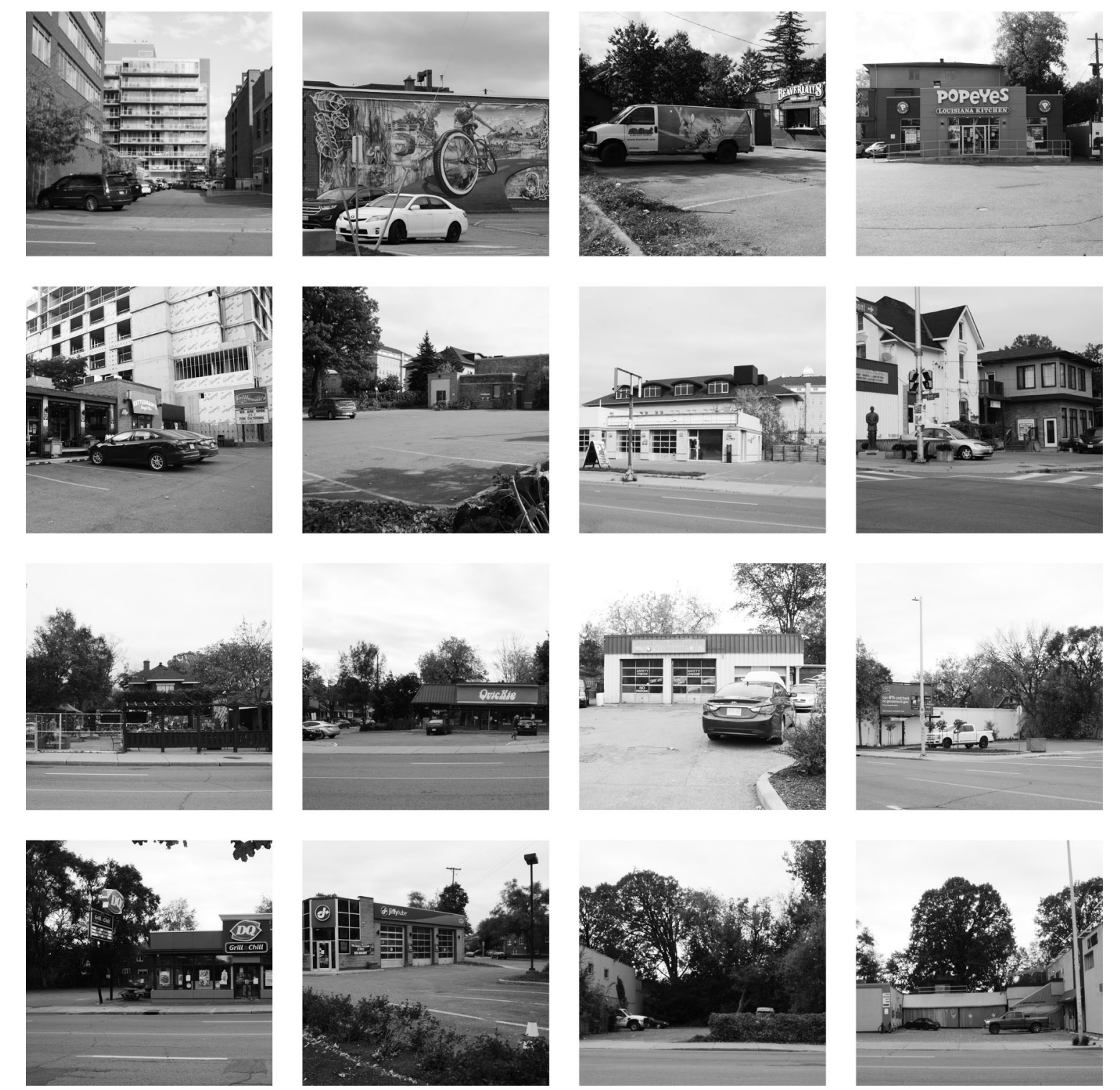

\section{PARKING LOT}

In both the Glebe and Old Ottawa South, surface parking lots are overpowering the urban fabric. In the Glebe, there are sixteen parking lots within fifteen blocks; and in Old Ottawa South, there are twenty parking lots within ten blocks. As proposed by professor, city planner and urban designer Eran Ben-Joseph in the book Rethinking a Lot, surface parking lots in cities could transform into spaces that promote community activity and play. ${ }^{42}$ This thesis discusses how the parking lot can be reoccupied with a variety of parks that cater to Bank Street's diverse public needs. A surface parking lot can turn into a playground for kids, while another can become a seniors' gym. 


\section{STREETS OF TOMORROW}

METHODOLOGY 
Figure 3.1 - Eliza and Adela Andrew's Lemonade Kurtis Andrews, Ottawa 2016. @ Photographed by Kurtis Andrews.

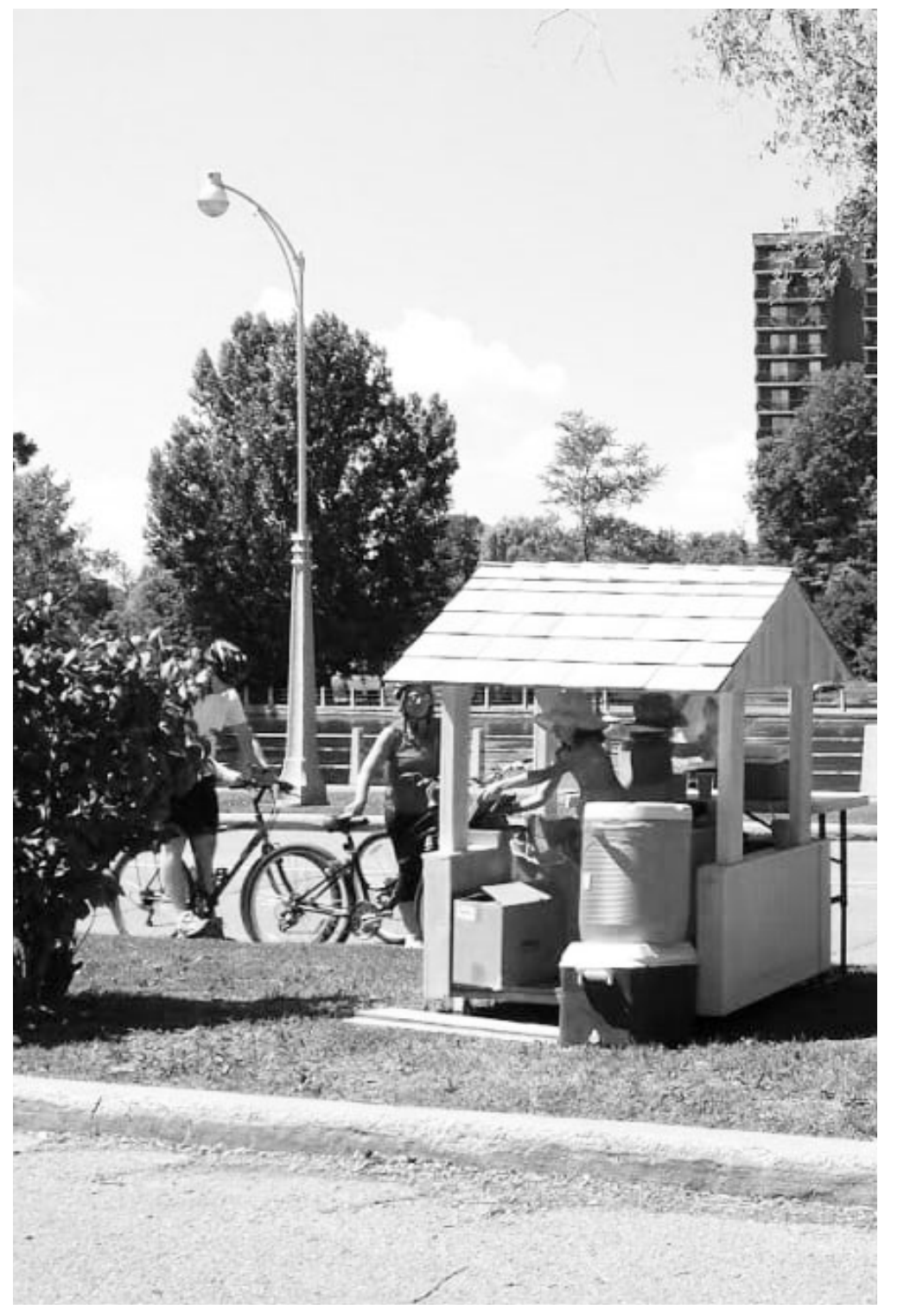

\subsection{EMERGENCE}

A NEW CITY-USER

This thesis argues for filling the gaps with infrastructure or temporary activities that boost street life in order to reimagine a public space continuum. Nevertheless, as the capital city, Ottawa is constantly struggling between providing its people what they need or maintaining the image of status that belongs to a capital city. So far, the municipality has chosen to portray a prescribed environment of order and control, where urban space is tied to designated functions and official uses. As a result, Ottawa's pristine appearance and homogenous urban fabric pleases city officials and real estate investors but fails to reveal the diverse identity of the populations living within it. 
In 2016 two sisters -five and a seven-year-old Eliza and Adela Andrews- set up a lemonade stand along Colonel by Drive. For decades, lemonade stands have been a rite of passage for kids to learn entrepreneurial skills. Most of the time, this also represents a kid's introduction to street life and other urban activities. However, on this summer day, as the girls provided a service to tired bikers passing-by the canal, the NCC showed up to shut down the business, as the girls had no permit to sell on NCC's land (figure 3.1). ${ }^{43}$ These regulation tend to tighten the usage of urban spaces. According to Frank and Stevens, tight space's qualities opposed those of the 'loose space.'44 They prevent unpredictable performances in the public realm, instead building a dull environment where scenes along the street cast the same monotonous actions over and over again

Ottawa's governing body has realized the impact some restrictions have had on the public realm's detriment. With the new policies outlined in the New Official Plan, Ottawa hopes to repeal its denomination as "the city that fun forgot," 45 to become "the most liveable mid-sized city in North America." ${ }^{46}$ However, change cannot come from policy alone. After the lemonade stand was shut-down, citizens backlash at the NCC's decision through social media. A day after, the NCC granted the two girls a selling permit; and, a year later, offered more special permits to other young entrepreneurs. ${ }^{47}$ Frank and Stevens argue that although many spaces possess qualities that allow for 'looseness', it is up to the public to discover the pwzossibilities of interaction within the urban fabric:

"The emergence of loose space depends upon: first, people's recognition of the potential within the space and second, varying degrees of creativity and determination to make use of what is present, possibly modifying existing elements or bringing in additional ones." ${ }^{\prime 48}$

Through decades, restrictions in Ottawa have inhibited people's behaviourwithintheurbanfabric. In 2014, filmmakers Nathan Hauch and Amen Jafri produced a documentary The City that Fun Forgot? - exploring Ottawa's reputation as a government town. In the film, politicians, journalists and artists discuss how, through the years, Ottawa has been trapped within a culture of conformity; they criticize the youth as either seeking complacency in a government job or escaping the city searching for creative outlets. ${ }^{49}$ Although the tech industry seems to have disrupted this way of thinking among the youth, encrypted behaviours like those 
70 Filling the Gaps

highlighted above still remain coded in the urban fabric. For

a shift in behaviour to occur, a series of tactical interventions

are designed within the gaps for people to interact with the

city and rediscover the public realm's possibilities. 


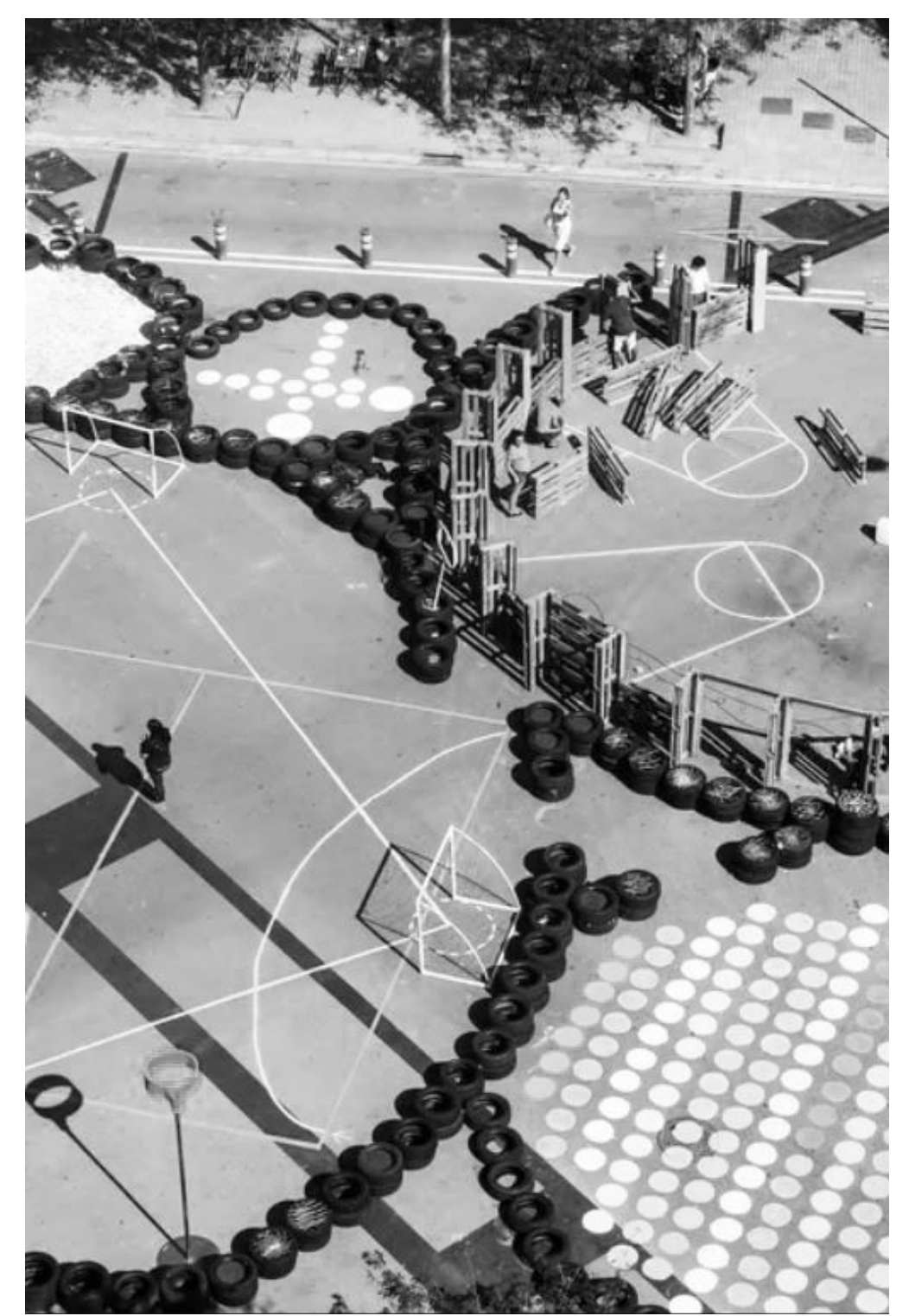

\subsection{TACTICAL URBANISM}

THE POBLENAU SUPERBLOCK

Tactical Urbanism is an approach to city building where "fast, low-cost and high-impact" ${ }^{50}$ changes are introduced to underused urban areas. Urban dwellers and larger entities alike can initiate these projects, but they always require individuals' participation to test and experiment with the spaces..$^{51}$ The municipality, developer and designer can later receive users' feedback and implement more structural modifications. Over time tactical changes can define spaces and transform the way people relate to the urban fabric.

The Poblenou Superblock in Barcelona used tactical changes to help inhabitants reimagine a human-centric narrative within the street. For more than thirty years, urban ecologist 
Salvador Rueda has been pushing the city to redraft its grid and grant priority to pedestrians. Rueda redesigned a new grid, defined by groups of nine-city-blocks, which delineate pedestrian-only-zones. ${ }^{52}$ In 2016, schools of architecture in Barcelona and Rueda submitted a proposal to the municipality to create a superblock in the Poblenou district. The municipality granted the permit to close one of the streets to traffic in order to test things out. ${ }^{53}$ Using paint, tires, potted plants and wood crates, the students created a series of play spaces along the street (Figure 3.2). While some

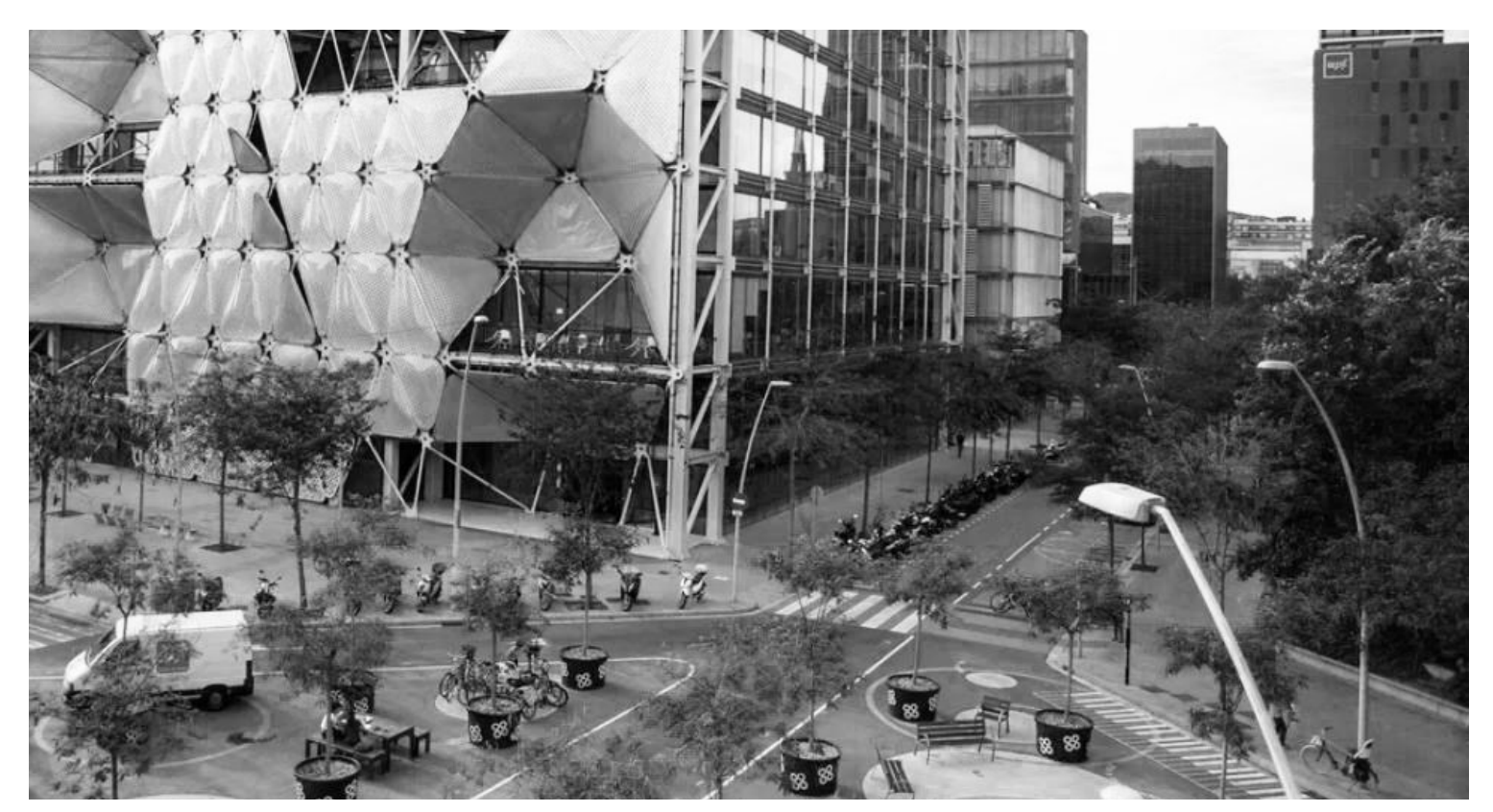

Figure 3.3 - The Poblena Superblock, Barcelona,

2016. () Photographed by

Maysun. citizens found the interventions disruptive, others used the space to meet and talk with neighbours. They discussed how the tactical interventions could feel more permanent and eventually requested the city to replace the tires and wood crates with more temporary urban furniture (Figure 3.3). ${ }^{54}$ Rueda explains that participatory urbanism is essential, as once pedestrian spaces are carved in the city, inhabitants should decide what uses are needed..$^{55}$

Tactical Urbanism stands as a response to the slow and bureaucratic urban planning processes. It requires citizens' action to curate the urban fabric gaps like unused alleys, empty parking lots, dismissed corners, and narrow sidewalks. Now that the City of Ottawa is drafting the New Official Plan, the municipality should consider this inclusive approach to building the city. The outlined policies currently address the need to transform the city's urbanscape; and allow for walkability, culture, and innovation to flourish. However, the document does not address how to involve the public in the physical redesign process, perpetuating citizens' role as passive consumers.

In Ottawa, as in many North American cities, restrictions 
and controls within the urban fabric have forged a culture of citizens that must conform with the activities and experiences available or provided to them, rather than creating spaces that satisfy their own cravings. People need to rediscover the many capabilities public space has to offer. For this, a new street user must emerge one that, as described by Frank and Stevens, appropriates public space "to pursue activities not set by a predetermined program." ${ }^{56}$ In this thesis, this new city-user is referred to as an urban dweller. Tactical urbanism is a practice that involves the appropriation or occupation of the urban fabric. Sociologist Saskia Sassen states that "to occupy is to remake, even if temporarily, a bit of territory, and therewith to remake its embedded and often deeply undemocratic logistics of power." 57 Tactical interventions can promote people first to interact with urban spaces, eventually change spaces to suit their needs, and finally produce the public realm continuum. This process, in the end, can redefine the role of the citizen within the urban fabric. 


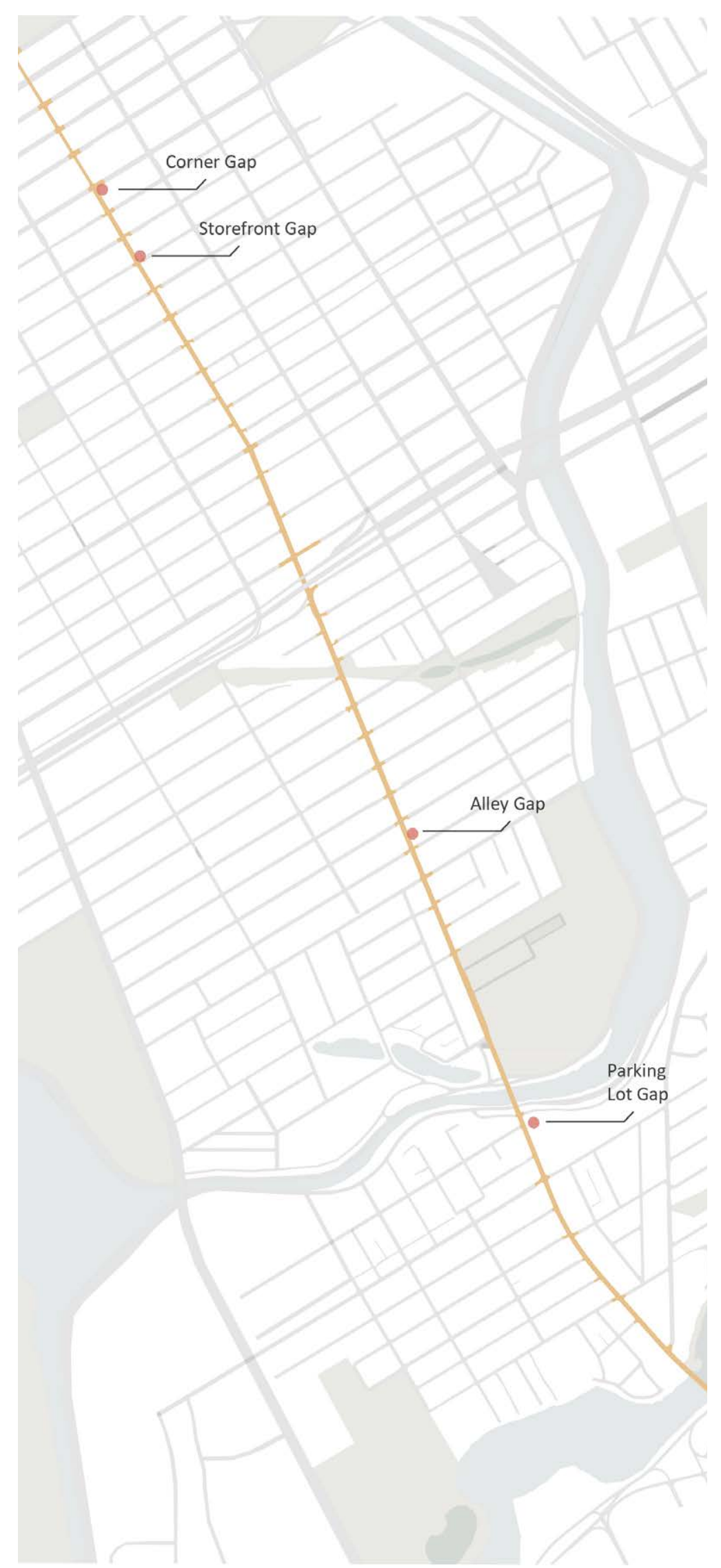

\subsection{GAP TRANSFORMATIONS}

CENTERTOWN, THE GLEBE AND OLD OTTAWA SOUTH

As addressed in the New Official City Plan, there is a need

for a more engaging and livable urban fabric in Ottawa. ${ }^{58} \mathrm{~A}$ proposition by the city is the creation of living streets, which refers to:

"[...] the seasonal or temporary reallocation of space within our streets from primarily serving vehicles to providing a range of amenities that serve people in a manner that supports placemaking and healthy 15-minute neighbourhoods while informing permanent street design."159

Based on this proposition, this thesis suggests a strategy of participatory implementation to transforms the street from a space of passage alone to a space for connection and human interaction. A continuous space where public life can 
emerge.

The thesis project consists of taking a closer look at four specific gaps along Bank Street and explore their spatial potential for publicness in the urban fabric (figure 3.4). Two of the gaps are in the Centertown neighbourhood. One is the open corner of L'Espleannade building complex, and the other one is the Wallack's storefront. The third gap is an alley in one of the blocks of The Glebe. And the fourth gap is the surface parking lot outside of the Old Ottawa South Public Library. Each site is reframed through tactical interventions to tell a new urban narrative and re-construct the neighbourhood's spatial identity. The interventions consider the unique spatial conditions and physical features of the gap, the neighbourhood's analysis and demographics, universal accessibility needs, and the different policies outlined in the New Official Plan.

The first step in the interventions is always tactical in nature For walkers to rediscover the various possibilities, the urban fabric has to offer. The goal is to create flexible and playfu urban spaces with designs that users can modify or adapt with time depending on their needs, allowing a performative response within the grid. With time, a new city-user can emerge, one that takes ownership and adds value, such urban dwellers would be invested in protecting and enhancing the public realm's interests. Eventually, renegotiations can start to occur among urban dwellers, municipality, and private entities to implement structural changes. At this stage, public space can be repurposed to serve the always-changing social context.

In this thesis, the focus was not on the building process or materiality of the interventions. But instead, on suggesting the design of a strategy that returns life to the streets. Looking at the city scale for a possible formation of a public space continuum, rather than focusing on a singular gap. However, the basic design principles that must be considered for the interventions are lightweight materials and ease of assembly. Specifically, when thinking about the starting phase of the intervention that has a more tactical nature. At this stage, individual urban dwellers can initiate the implementation of simple tactical interventions. With time the effort can become communal, and more 
extensive tactical interventions can be built through social participation. Neighbourhood associations and storefronts that want to be part of this transformation can later be responsible for implementing daily or seasonal changes. When a site is ready for a more structural intervention, it will be the city that helps the neighbourhoods and urban dwellers implement this larger project.

The design interventions to each site are drawn as a series of vignettes to represent the transitional changes public spaces can experience through time. During the thesis defence, the vignettes were displayed as GIFs that can be accessed through the link below. The GIFs can be watched after reading the following description for each gap.

\section{LINK:}

https://drive.google.com/drive/folders/11XP QDCtDoe5FpTQ37yVKnQtJTKMG5Gr?usp=sharing 


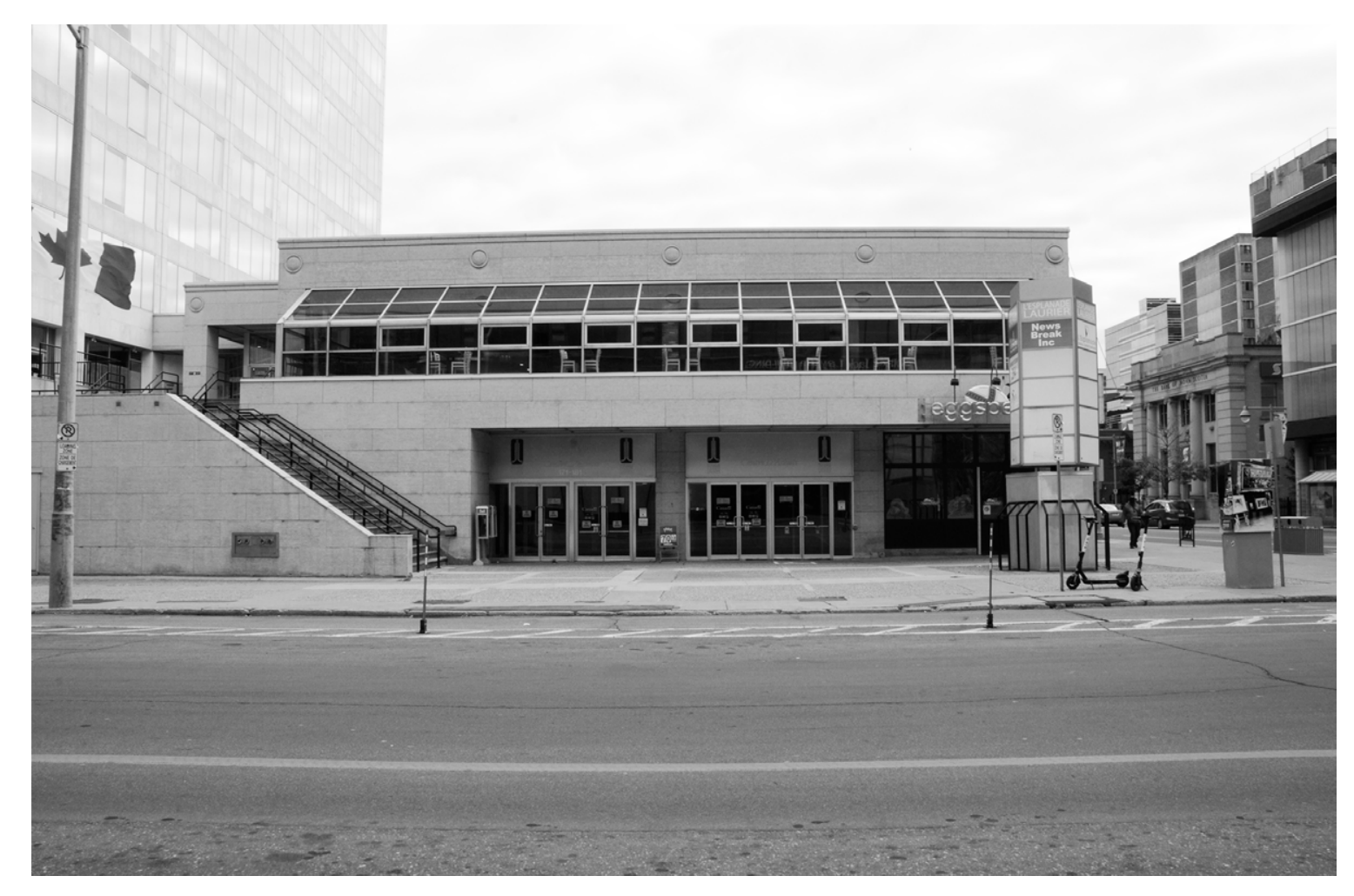

\section{OPEN CORNER}

Figure 3.5 - L'Esplanade

building along the

intersection of Bank

Avenue, Ottawa, 2020

(c) Photographed by the

author.

In the Centertown neighbourhood, along the intersection of Bank Street and Laurier Avenue, in front of L'Esplanade building, lays an open corner. The federal government owns the site and occupies this building's higher levels as office space. While the ground floor hosts commercial spaces that open to the street. The open corner has a rectangular footprint with similar conditions to a public square. However, other than people passing through, not many activities can happen as there is no infrastructure for people to inhabit. The municipality and the federal government can work together to rehabilitate this gap into an urban space that meets cultural and social needs in the city. 
With the expected population growth for 2036, the New Official Plan establishes that current city neighbourhoods will need to host at least $60 \%$ of all new dwellings. ${ }^{60}$ This entails higher densities within the same footprints, so city residents can expect to inhabit smaller residential spaces in the future. Some events that occur in our homes' privacy today will need to move to the outdoors due to lack of space. So perhaps, instead of gathering with friends in the living room, city dwellers will choose to meet in public spaces like this one.

The pavement pattern grid, already on-site, guides the form of the design intervention. Through a series of movable and stackable rectangular pieces, a gathering plaza is shaped. Being on the corner, this space can turn into a neighbourhood focal point. People can stop by during their day-to-day activities when passing by or choose to come to this space to take a lunch break outdoors while chatting with a friend. The design can be modified throughout the day to meet different urban needs. During lunchtime, a sitting area might be more appropriate; at nighttime, the corner can transform to host events or performances. With time, urban dwellers can also modify the structure and discover new uses for the space.

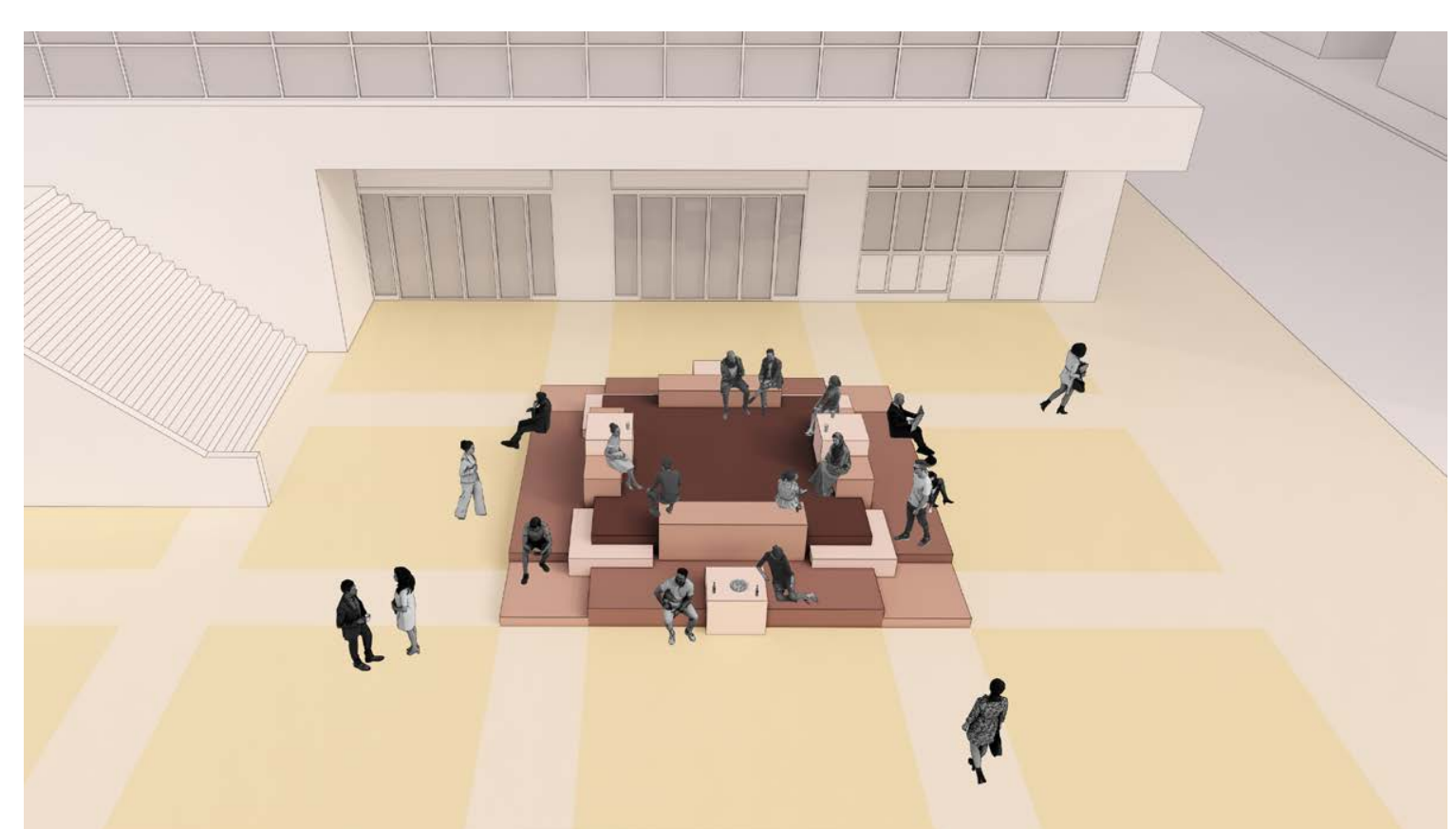



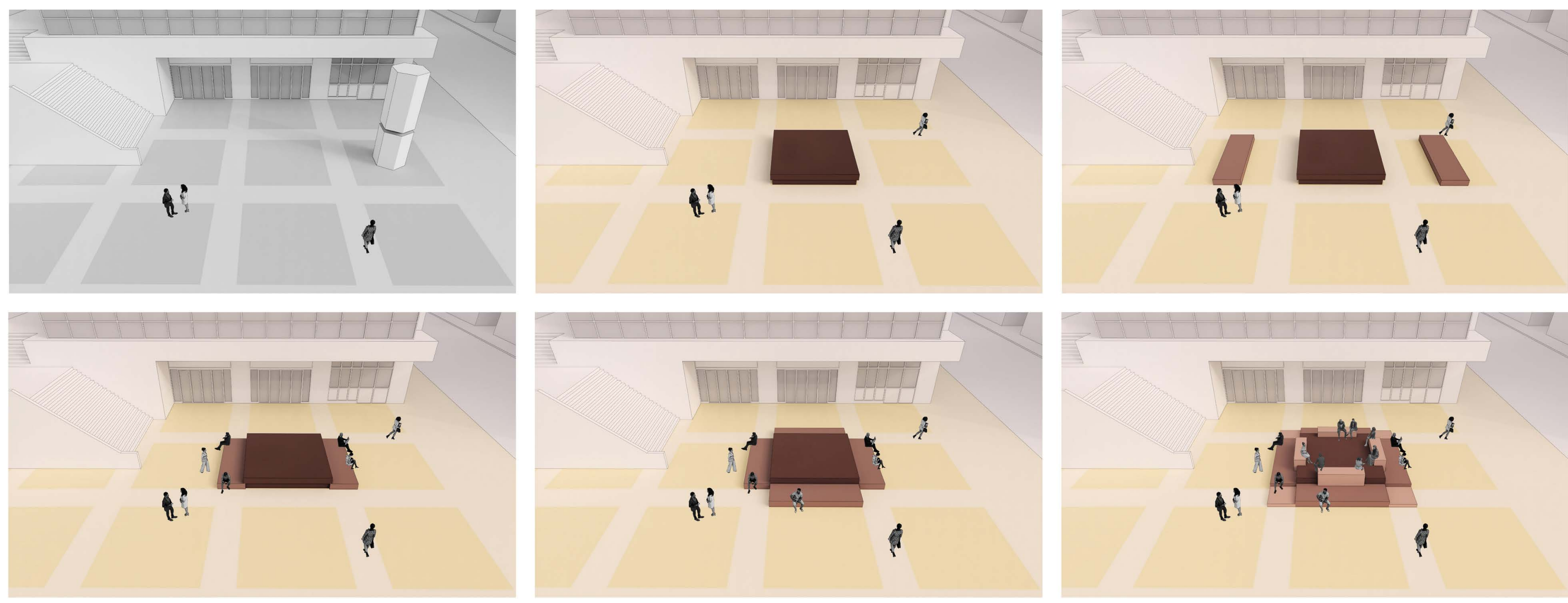

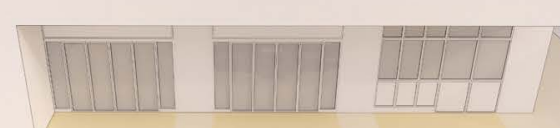

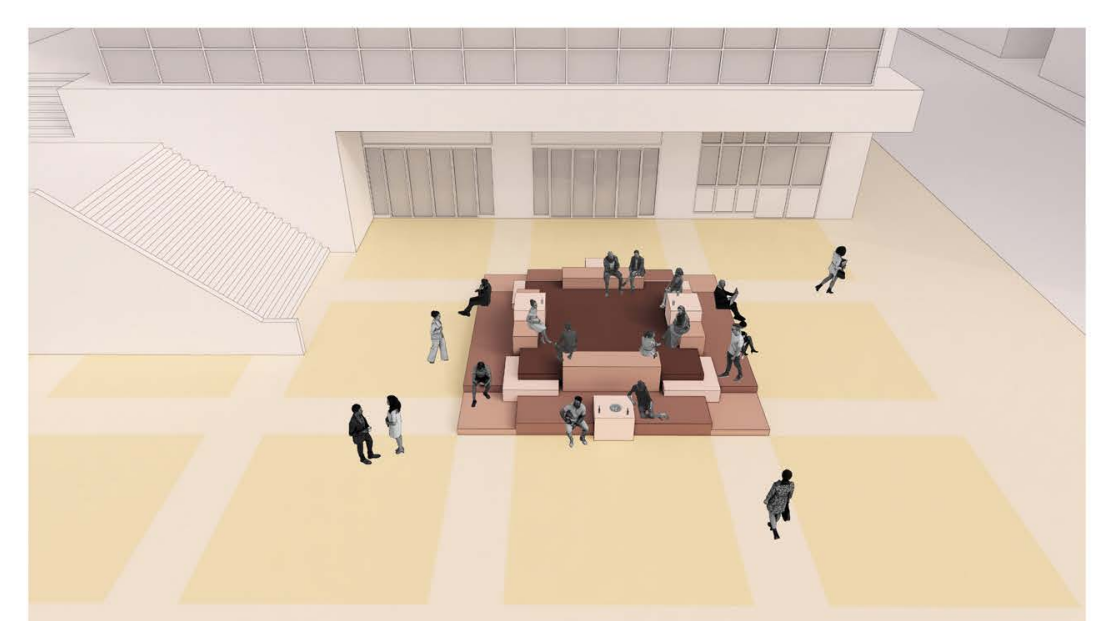

Figure 3.7 - Transition o corner intervention.

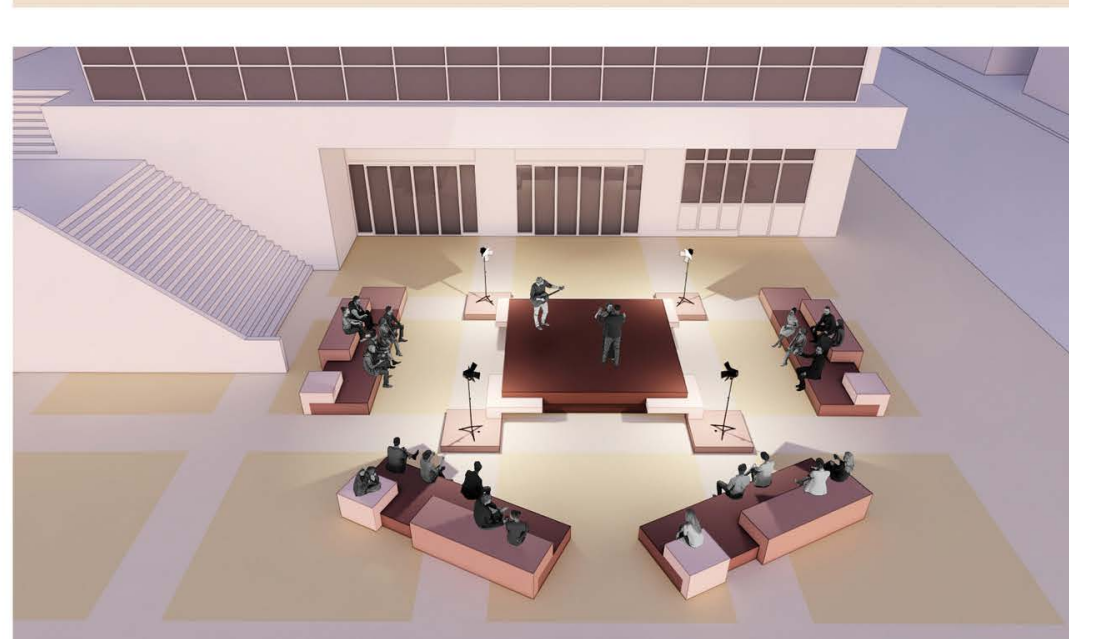




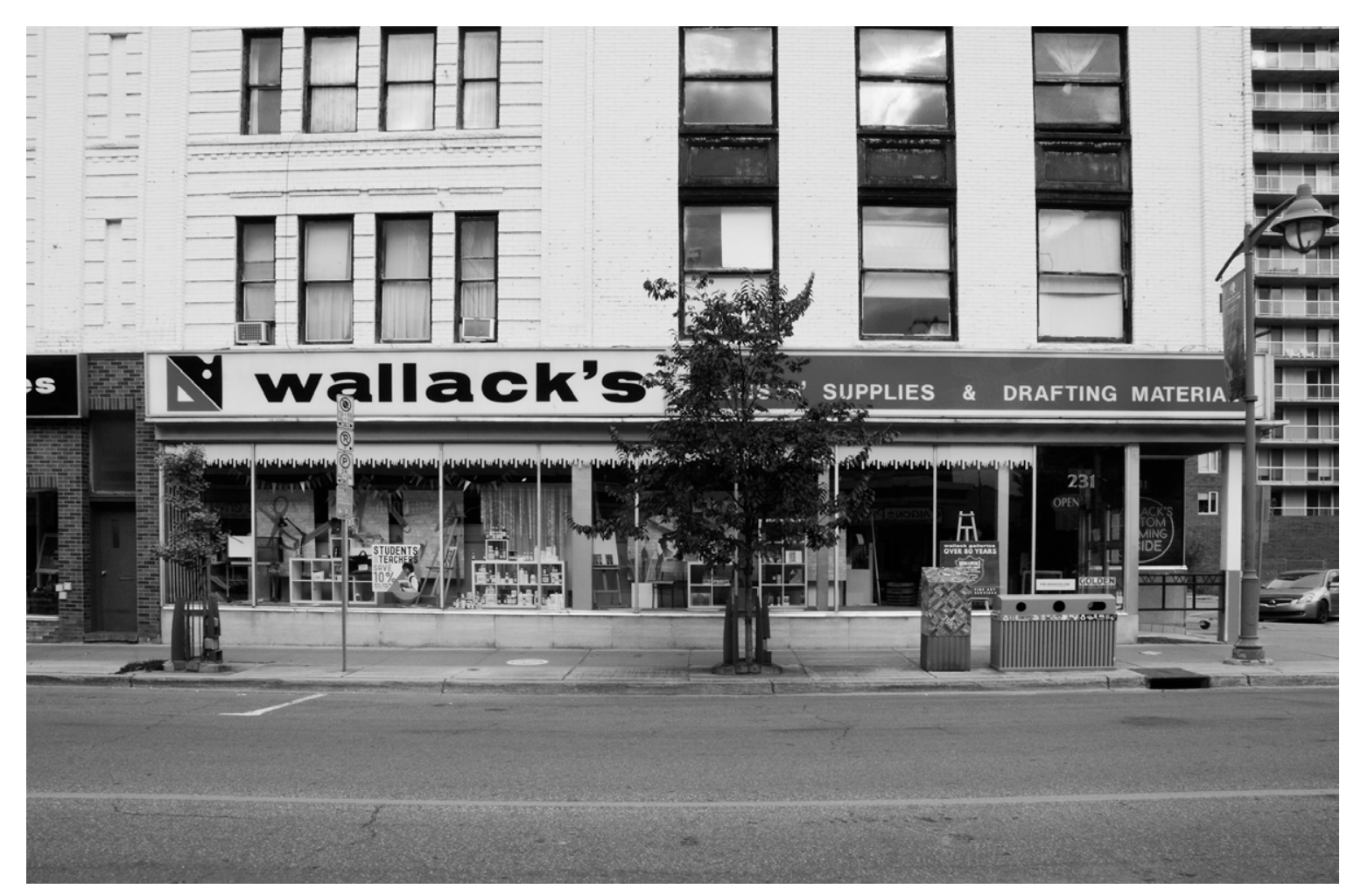

\section{STOREFRONT}

The Wallack's storefront in Centertown, located at 231 Bank Street, is another space for a possible intervention. In this case, the space agency is shared across by different actors. The storefront is a private space owned by Wallack's, while the sidewalk is a public space owned by the municipality and sought over by the public.

There are two proposed interventions for the storefront gap. The first one borrows a portion of the street parking in front of the shop. This extra section of the street can be used to create a gathering space for the neighbourhood. Centertown has the highest percentage of adult population living alone- 39.5\%. ${ }^{61}$ Therefore, communal areas where city- 
users can socialize and interact with others are imperative for this neighbourhood. At first, the use of this space can be temporary or seasonal. However, if there was a desire from urban dwellers for an all-year-long gathering area, the sidewalk can be extended by about $3 \mathrm{~m}$ to replace the street parking with spaces for people. During the summer, the gathering space can transform into craft tables where the art store can host workshops, while during winter, ice sculptures could be displayed.

The second intervention focuses on the storefront itself. At first, changes can be tactical in nature to educate walkers on the different possibilities streets and sidewalks can offer. By placing a thin bench and small tables on the sidewalk, walkers may choose to stop on this section of the street. This intervention allows the store owner to test the value of providing a quality environment that attracts more people to the storefront. Eventually, the store owner might want to modify the building's structure to integrate this bench and tables into the storefront display.

With time, the storefront can transform from a twodimensional barrier dividing the private and the commons.
Renegotiations can occur between the store owner, the municipality, and urban dwellers to extend the public realm. The municipality can develop a policy for businesses to share some space with the public realm so that everyone can enjoy the street. In the case of Wallack's, rather than having static products displayed on the window, the storefront can show human activity. Local artists can be invited to use the display section of the store as a workshop area or gallery space.

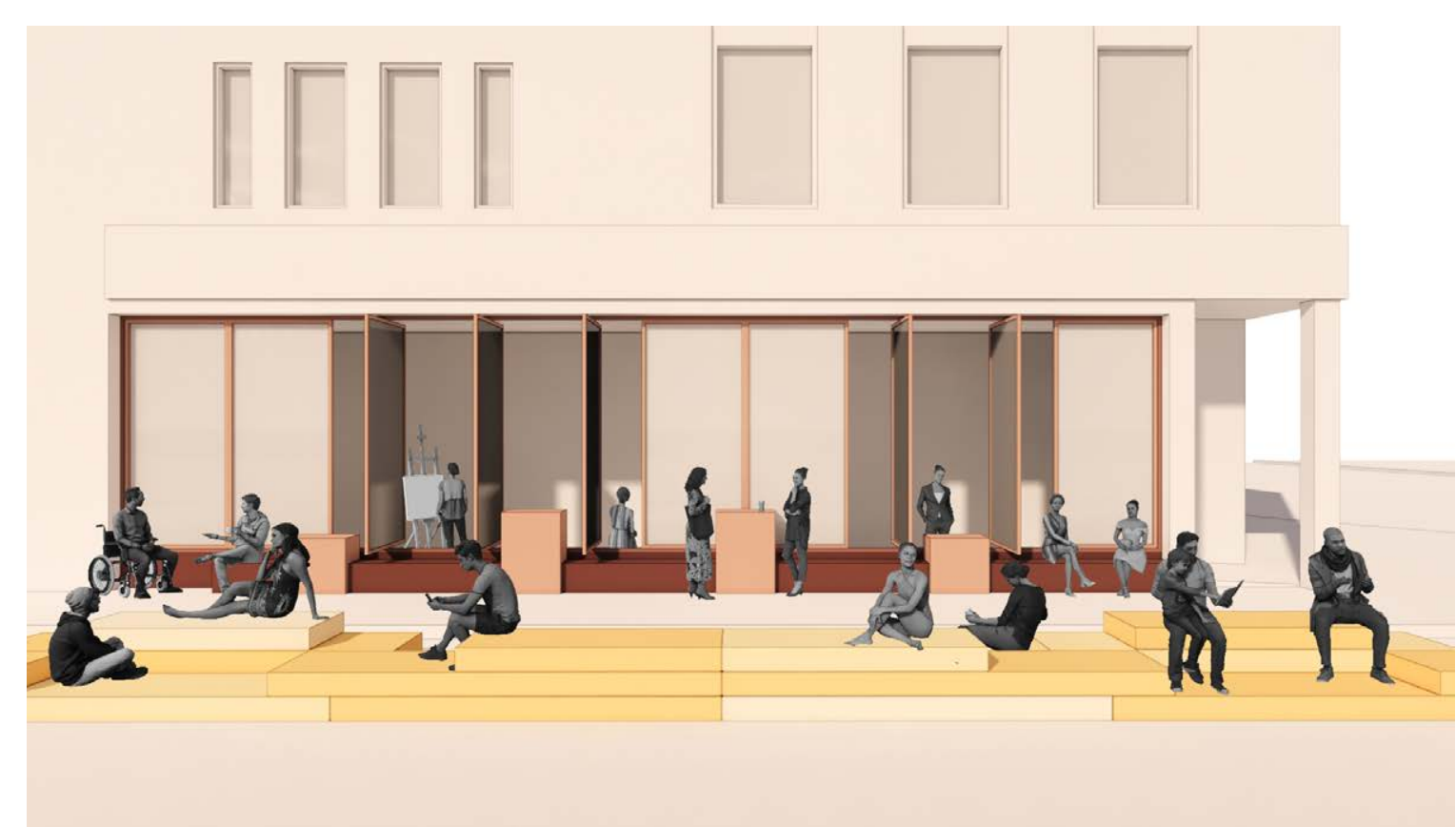

Figure 3.9 - Storefront intervention as an area to stop and stay. 

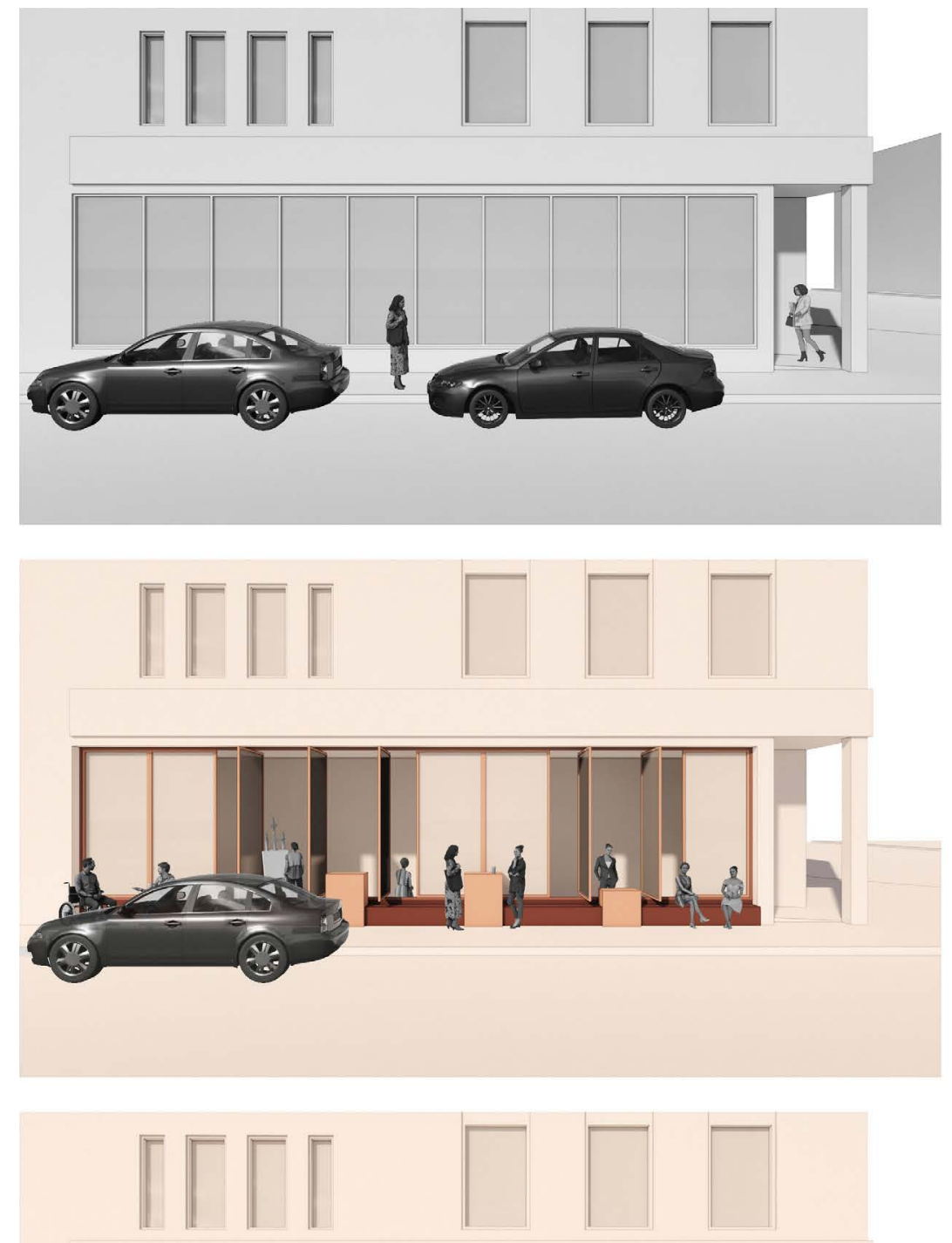

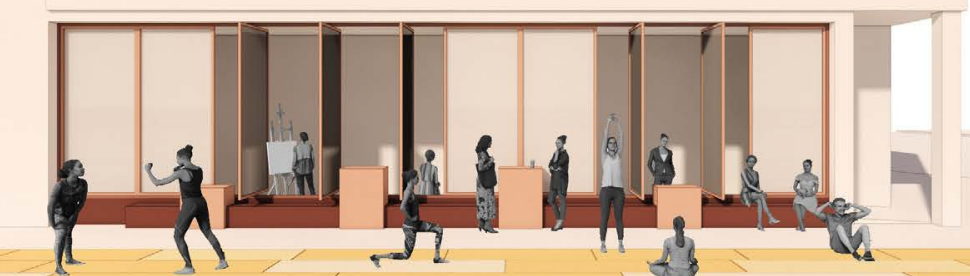

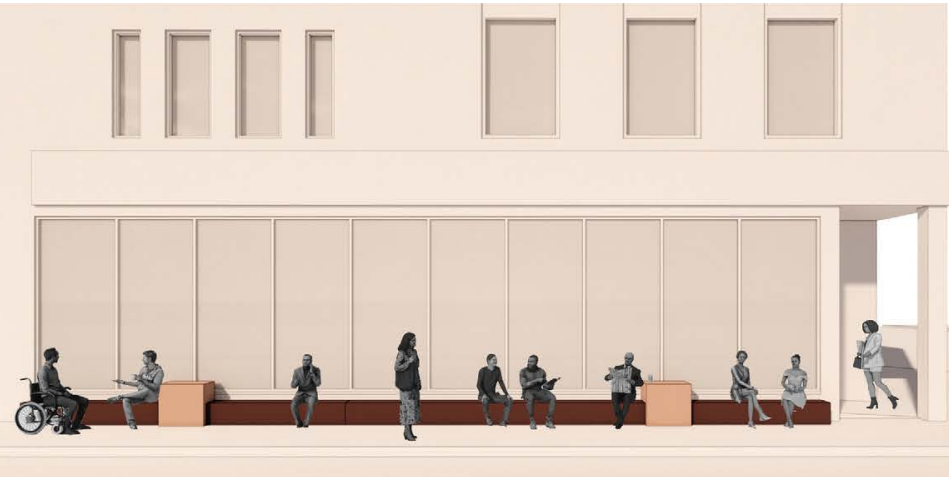

ГГГГ Г П П
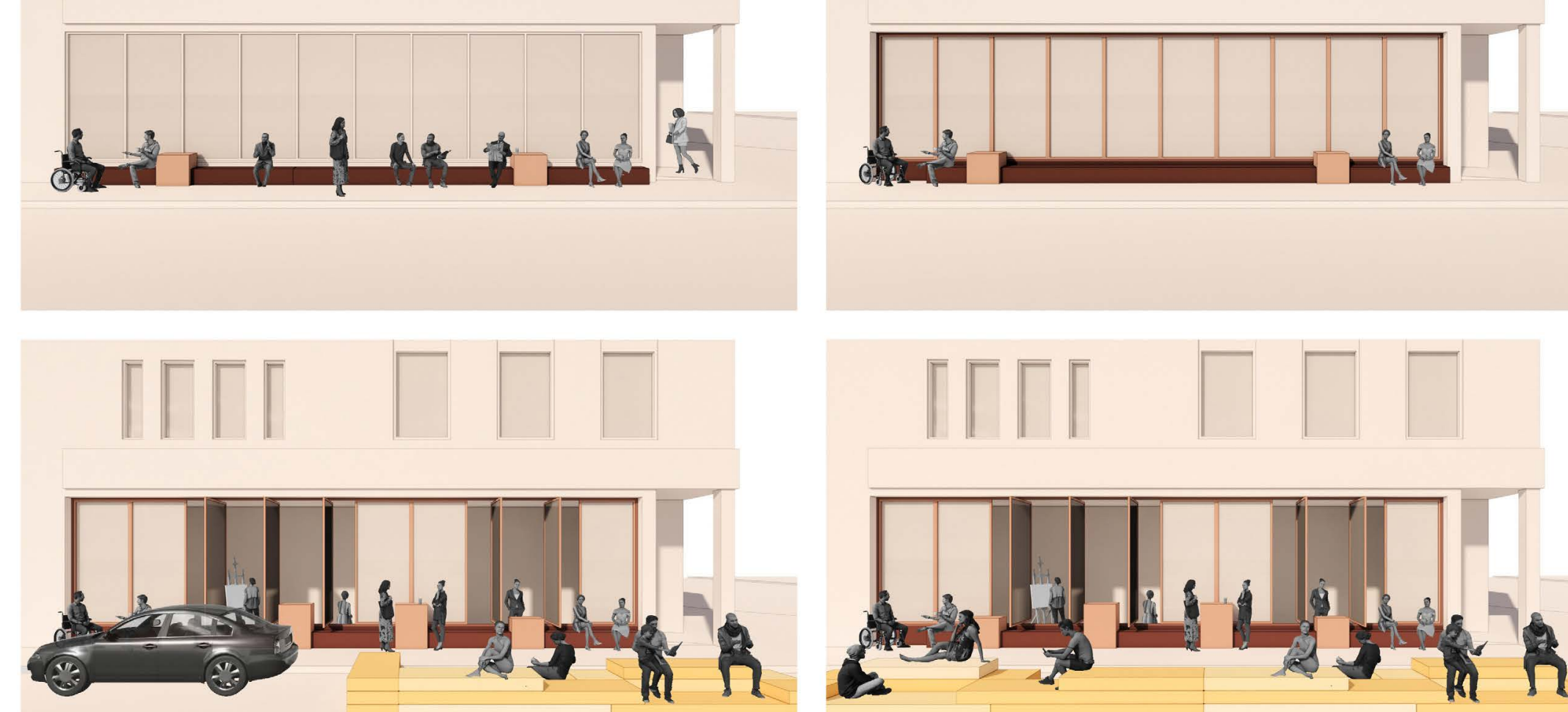

ГГГГ

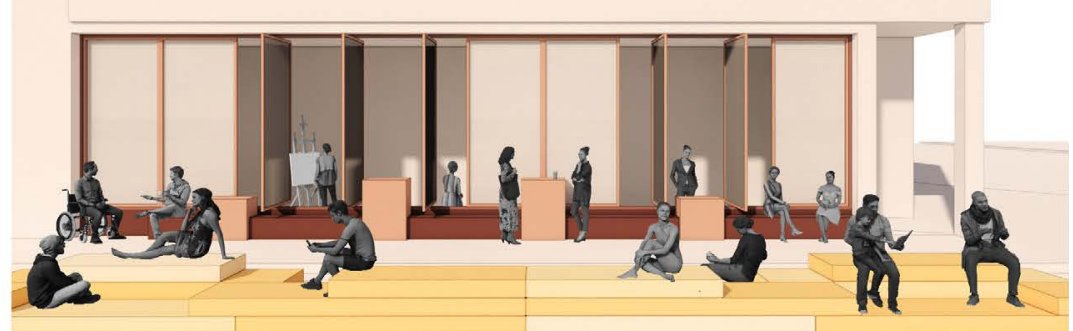

ГГГГГ.

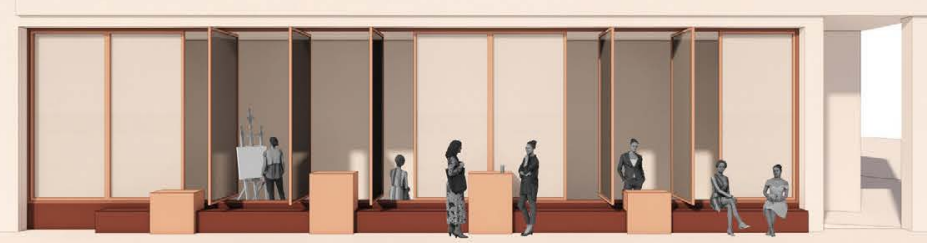

ГГГГГ

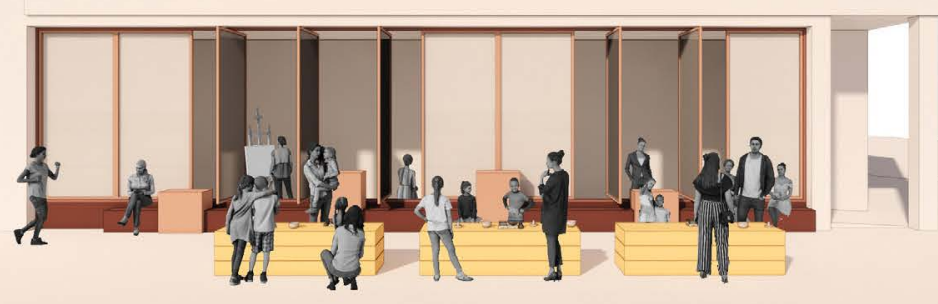




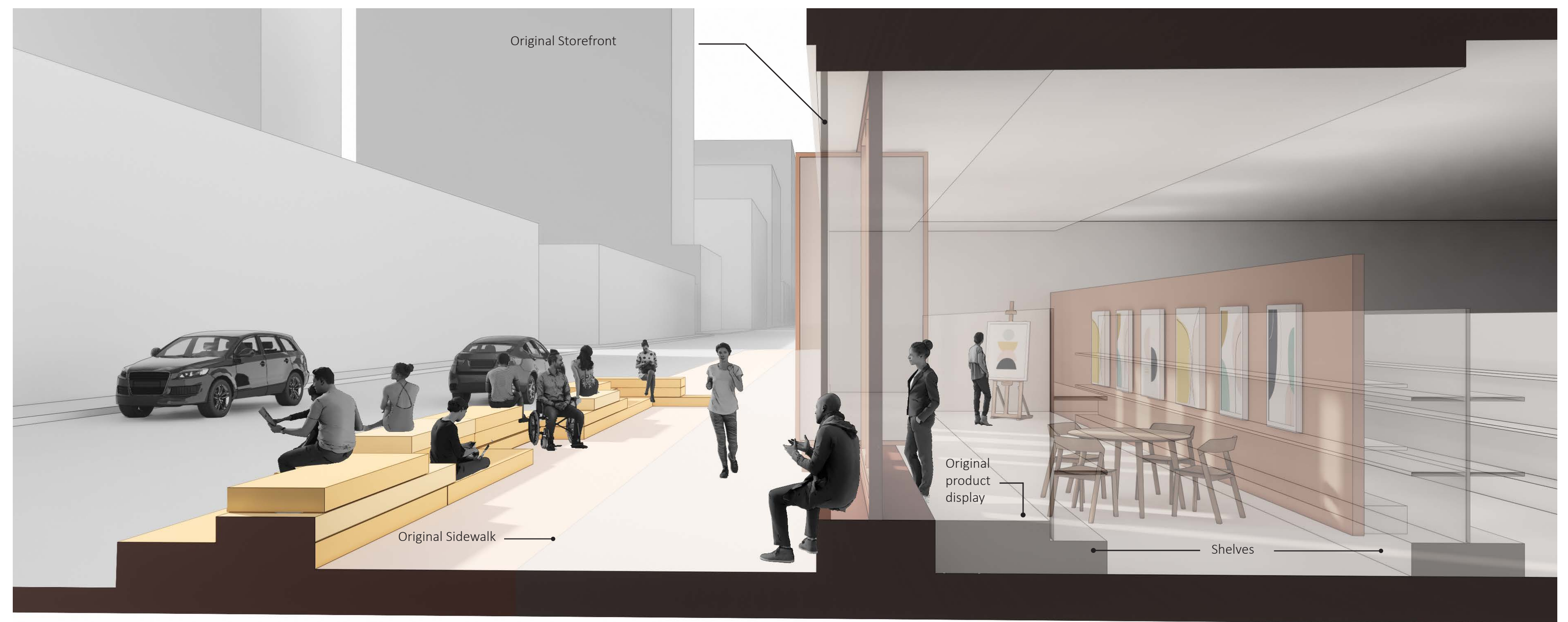




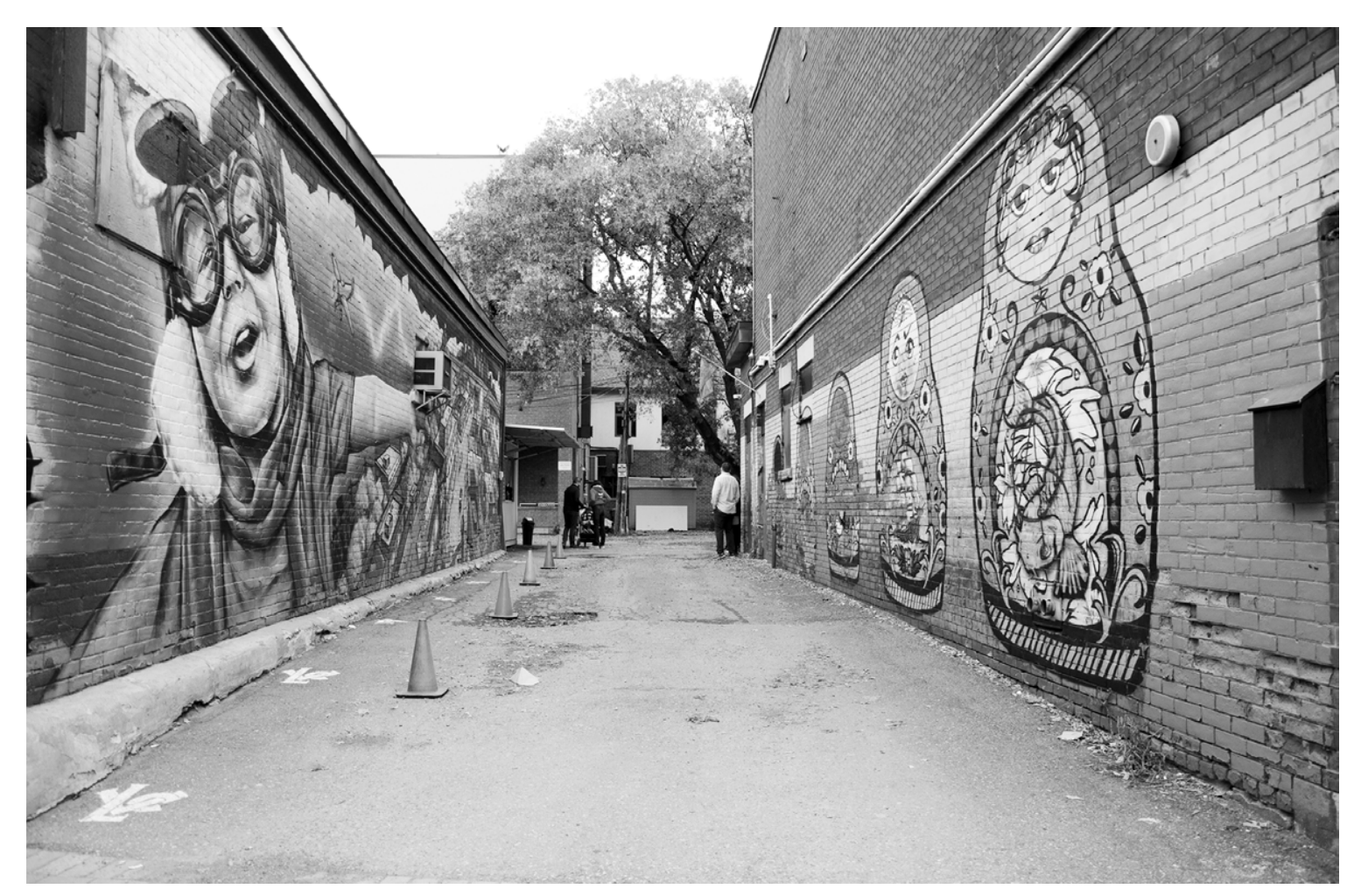

\section{ALLEY}

This alley is located in the Glebe, between two buildings, Little Victories Coffee Shop and the Good Cannabis Co. The building on the right is a one-storey shop, and the one on the left is a two-storey one. The rest of the street block mainly comprises two-level shops that host commercial space at ground level and housing on the top. On a day-to-day basis, this pocket is used by the residential community that lives behind to access garage spaces. There is a second entrance to this community on the side street, Fourth Avenue, where residents can access this space. Therefore, the intervention freely occupies the alley and repurposes it to benefit a larger portion of city-users.

Figure 3.12 - Alley in the Glebe within the block of Bank Street and Fourth (c) Photographed by the author. 
The intervention starts with a few platforms lined up on one side of the alley, where people can sit and admire the street art in front, showing a Glebe neighbourhood map. Within the passage, city-walkers can find a series of private urban spaces, like small nooks for thinking or self-reflection, that are not usually available on streets. This intervention can start as a temporary or seasonal space offering. Such opportunities for the use of urban gaps are overlooked by the businesses within the block.

However, with time, as the population density grows by $40 \%$ over the next 25 years, ${ }^{62}$ the municipality will need to find additional public space within the urban fabric. Along Bank Street, there are many two-level shops with flat roofs that, with some structural modifications, could be inhabited by urban dwellers. This intervention presents an opportunity to add structure to the initial platforms, similarly to how scaffolding is built, to develop a staircase for dwellers to move between levels. Creating a new dimension for the public realm by occupying the rooftops along.

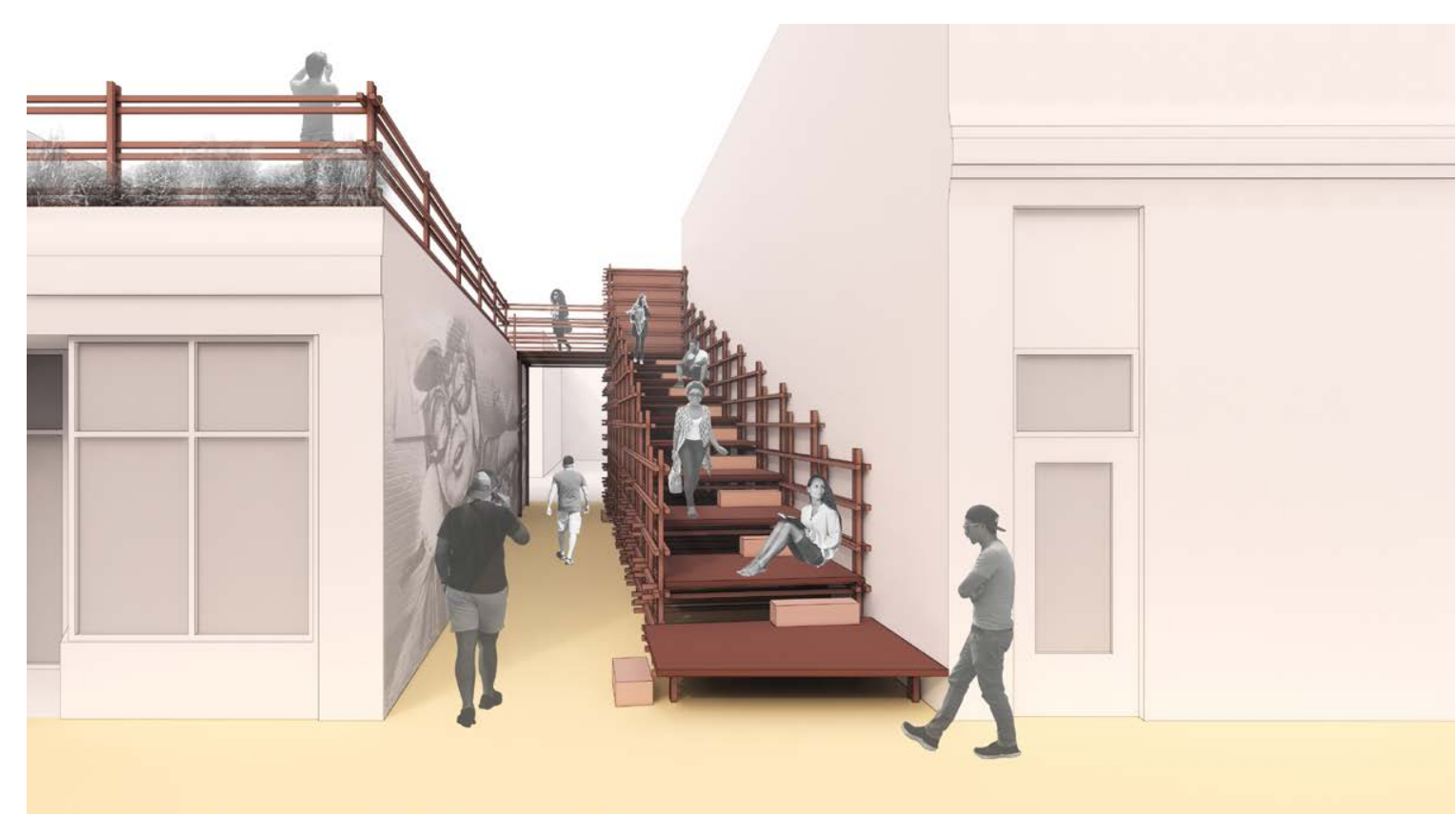




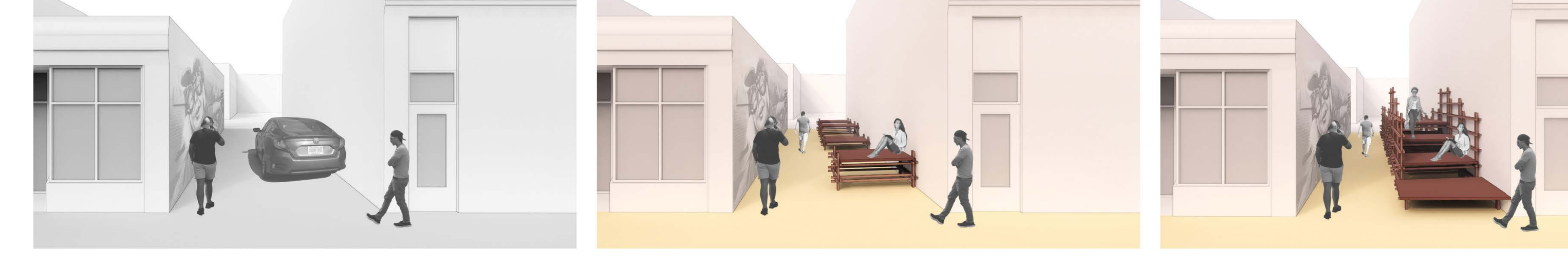

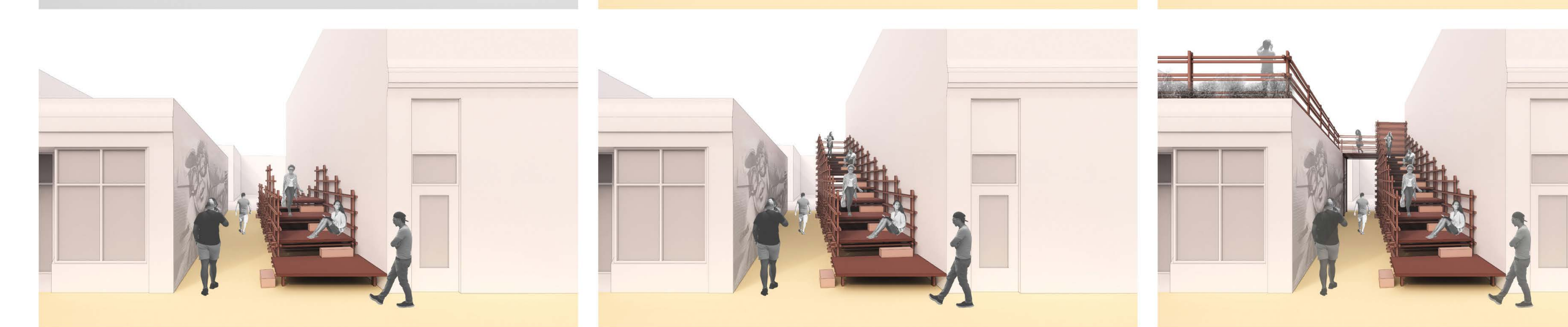




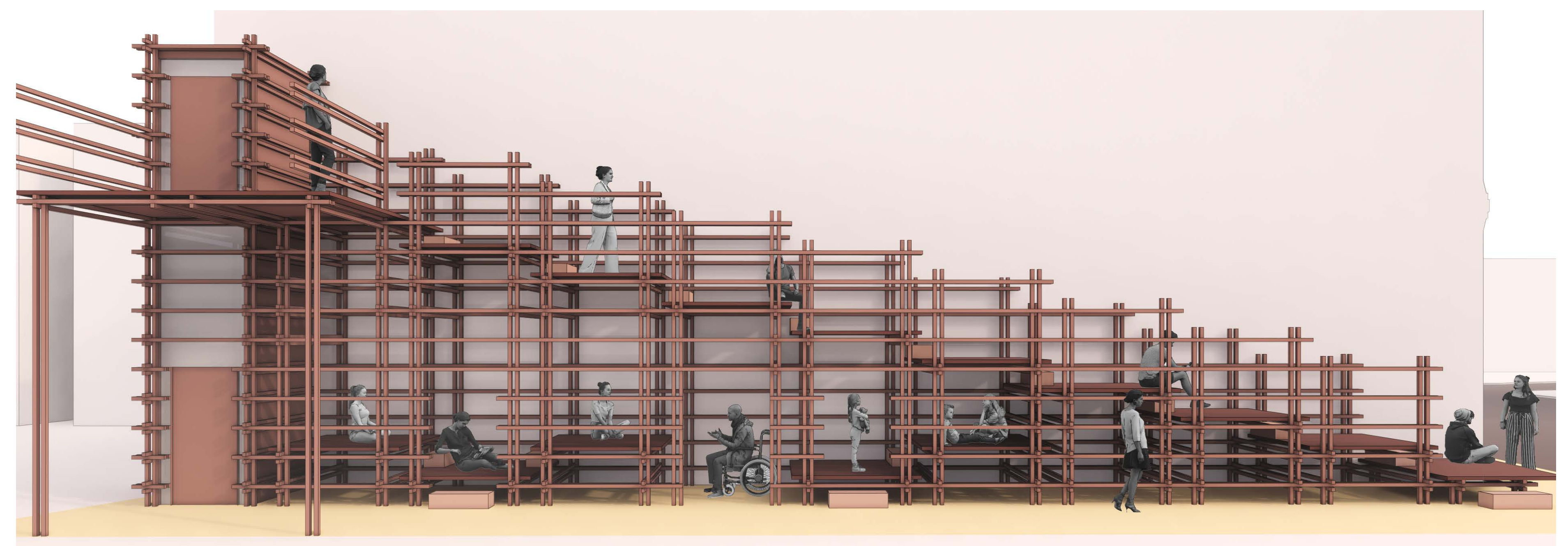

Figure 3.15 - Side

elevation of the alley

intervention. 


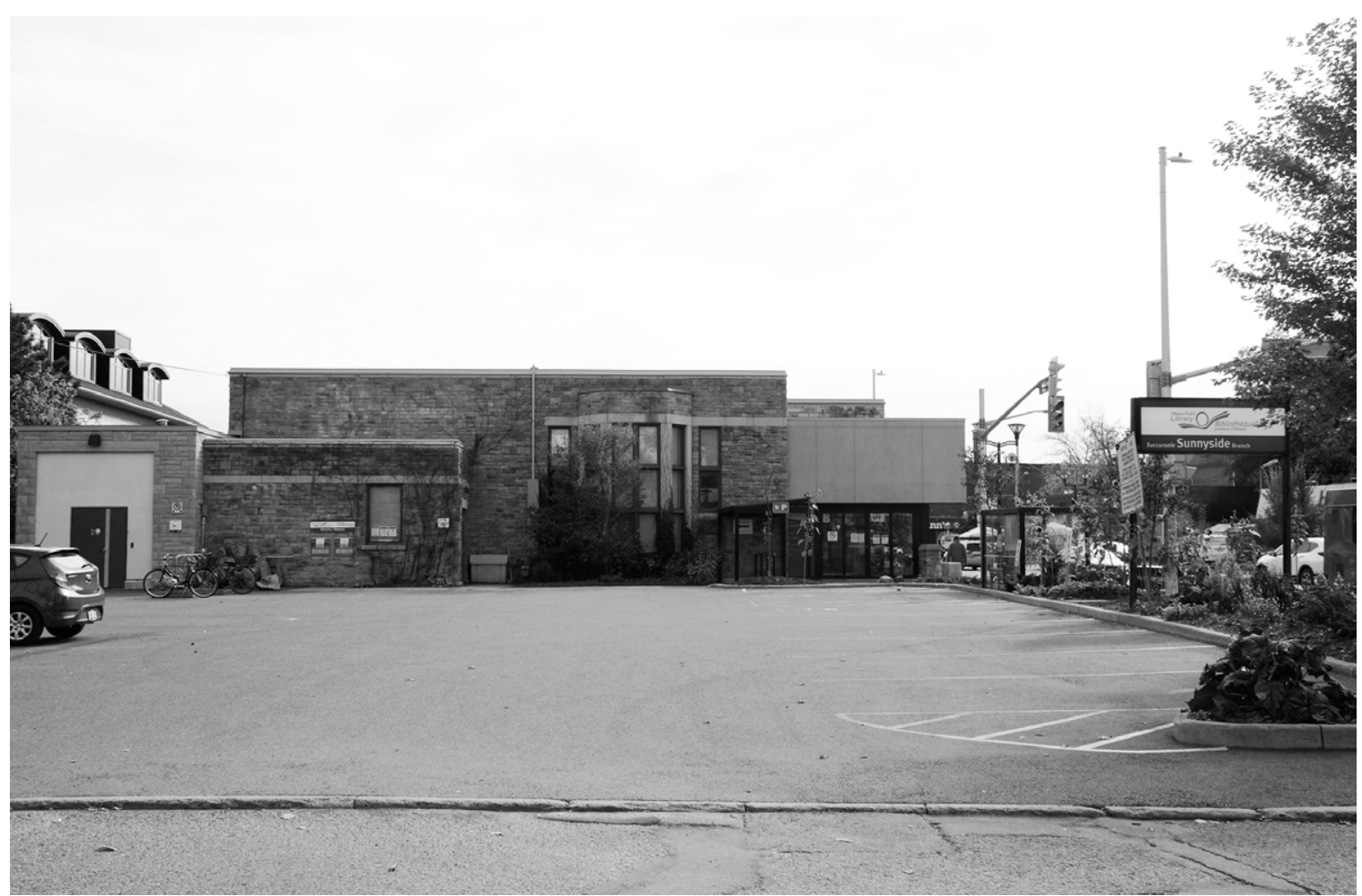

\section{PARKING LOT}

The fourth gap explored in this study is the parking lot in front of the Ottawa Public Library in the Old Ottawa South neighbourhood. In the New Official Plan, the municipality states that "by 2046, more than half of the city's trips will be made by sustainable transportation, including walking, cycling, transit and carpooling." ${ }^{63}$ From Centertown to Old Ottawa South, there are forty-one surface parking lots along the street that will become futile as the number of vehicles is reduced. This proposed intervention transforms the parking lot from a dynamic space for cars to an active area for people. As the Old Ottawa South neighbourhood is home to many

\section{Figure 3.16 - Parking}

Ottawa South Public

Library, Ottawa, 2020

(c) Photographed by the

author 
the population, ${ }^{64}$ the interventions focus on creating a play space for children.

The intervention starts at the parking lot's edges. Small spaces for play are created between the sidewalk and the parking lot, taking over only a few parking spots at first. The bus stop on the sidewalk is flipped sideways to integrate this area into the design. As the vehicles in the grid reduce with time, other portions of the parking lot are occupied.

The design is guided by the parking lot's painted lines. The lines are extended and copied perpendicularly to create grid. Large rectangular planters are added to the grid as a protective edge, while small rectangular and triangular pieces are added in the center for play. Kids can move these figures around, climb onto them, and build upon them to create different shapes when playing. In the winter, children can flip the smaller hollow shapes and place them on top of the larger rectangular pieces. Snowfall will fill-in the forms, creating snow forts for children to inhabit.

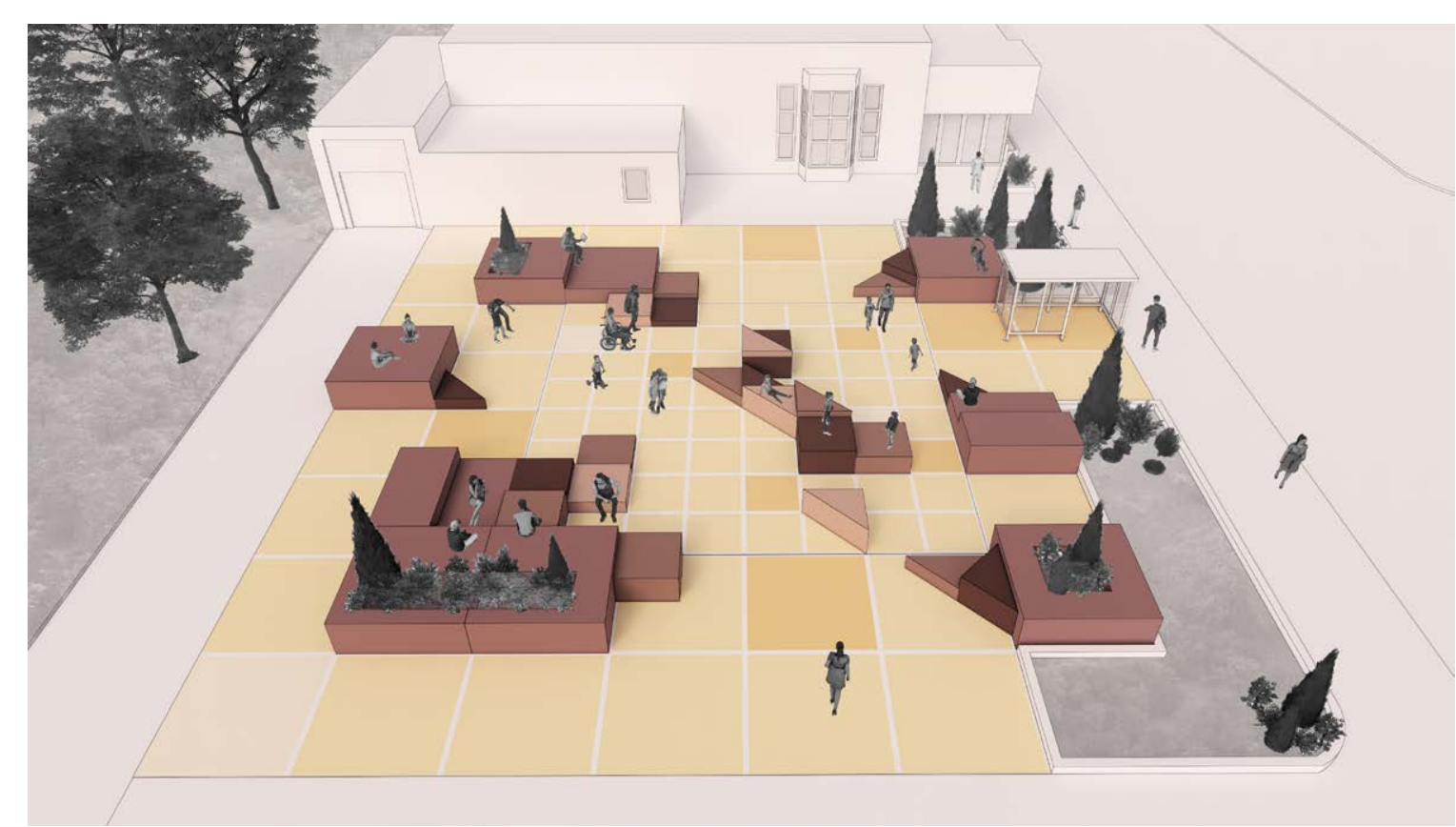



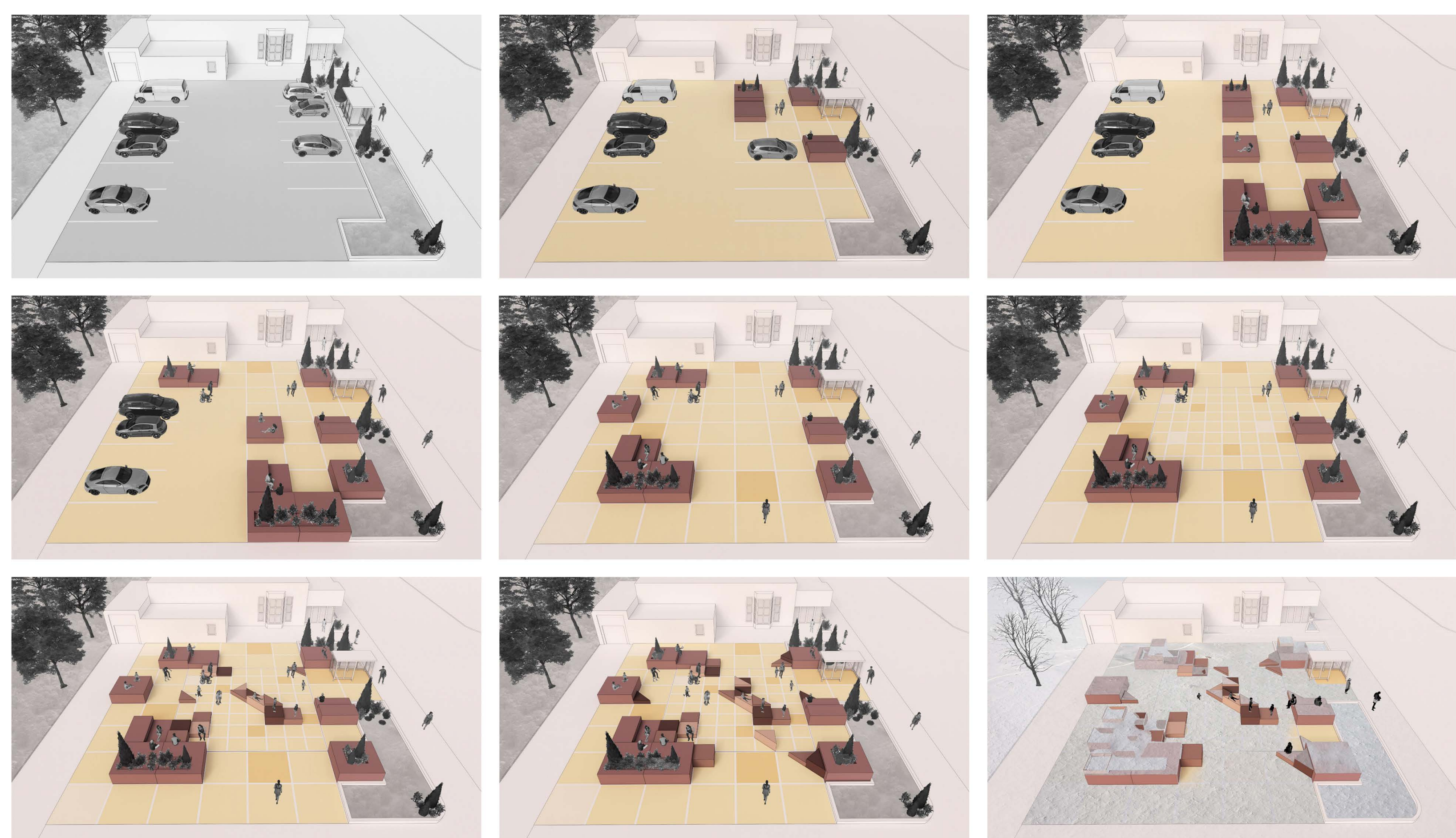


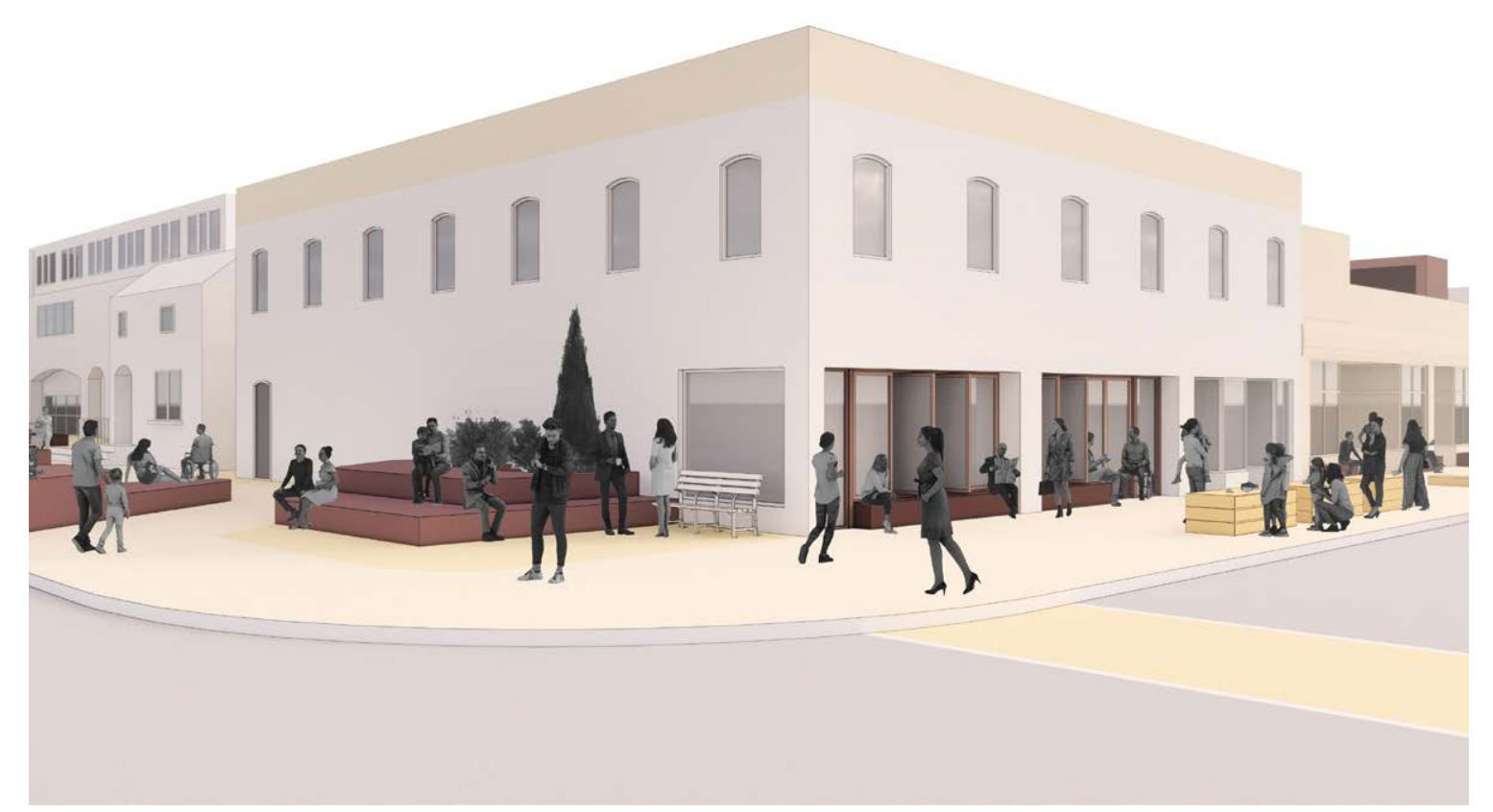

\subsection{REIMAGINING PUBLIC SPACE AS A}

CONTINUM IN OTTAWA

As pedestrians walk their daily routes, they will find spaces along their path that offer opportunities to take a break, socialize with others or interact with the city. By inhabiting the gaps and modifying the interventions to suit their needs, city-users can rediscover the 'looseness' that public space can offer. After occupying the gaps along Bank Street, urban dwellers may crave a diverse public space that provides more than circulation or commercial activities in other city streets. Some dwellers may see a need for placemaking in their neighbourhood. While other communities may seek open gathering spaces where they can meet-up, and certain storefront owners may desire to attract more people to their 
other city streets with infrastructure or temporary activities that help boost street life.

With the New Official Plan, the municipality has addressed the need to transform the urban fabric to allow for walkability, culture, and innovation to flourish. The need to transform streets into places for people to stay in, rather than just spaces of passage, is clear. Policies are in place to reduce the number of vehicles in the city center, reallocate temporary spaces for people and improve the city's fabric through urban design. However, as gaps previously occupied by vehicles become vacant, policies that directly claim a certain percentage of these spaces for the public must be in place. This reform must also be applied to existing commercial spaces along the street. Private owners should be asked to contribute space towards the public realm by offering a certain percentage of the corner, the storefront, the alley or the parking lot -as previously proposed by the interventions - to foster social participation and welcome people to the site. More populated and dynamic streets, in turn, will generate a broader audience of customers that businesses can cater to.
To make this thesis project feasible, the municipality will also need to grant a certain degree of 'looseness' in public spaces. This will allow for more cultural expression within the grid and include individuals in the process of producing the city. Urban dwellers should be able to make small modifications in the public realm to suit immediate needs. These unprescribed activities can forge a more diverse and livelier fabric. Neighbourhoods, on the other hand, should have control over more extensive improvements. Suppose urban dwellers want to add something to the grid or create a new tactical intervention within a gap. In that case, they should be able to acquire a permit from the neighbourhood itself. Granting urban dwellers the right to express themselves in the city and the responsibility to produce it makes it more likely for an accessible and diverse public space continuum to emerge. 
The following vignettes show the process of filling in the gaps within the block of Bank Street and Third Avenue. The

first vignette depicts the block's present conditions (figure 3.20). Here the street's spaces are only functional for circulation or commercial activities. In the second vignette, the street gaps are filled with tactical interventions that help boost street life (figure 3.21). As people rediscover the potential of public space, unprescribed activities repopulate the grid. With time, as the design interventions spread onto every city gap, a public space continuum is conceived (figure 


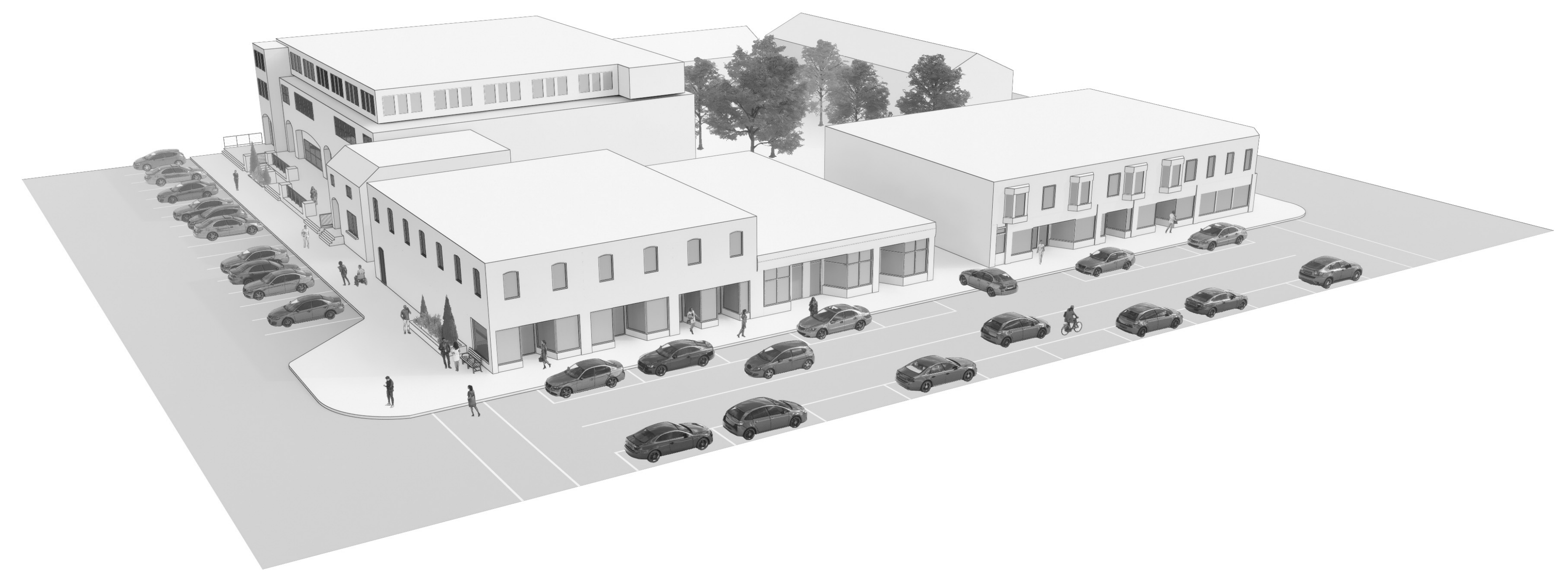




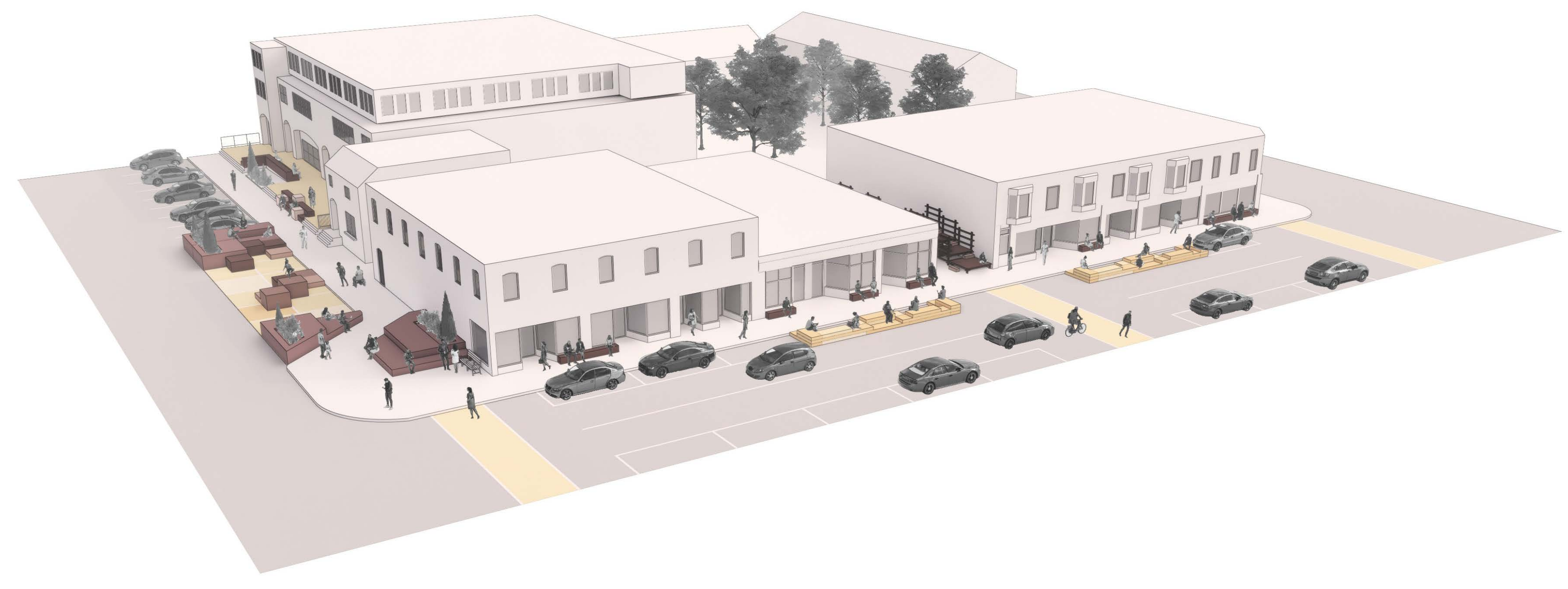

Figure 3.22 - Street gaps 


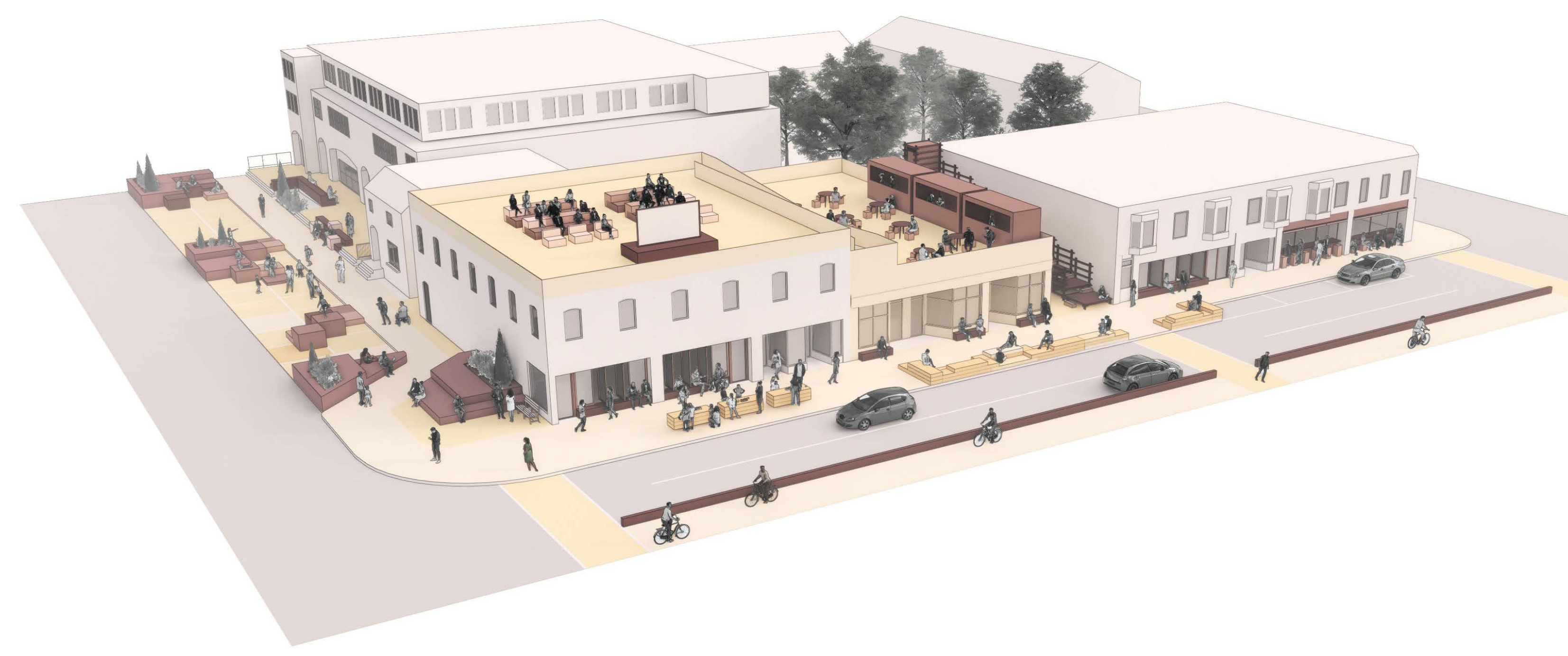

Figure 3.23- With time as 


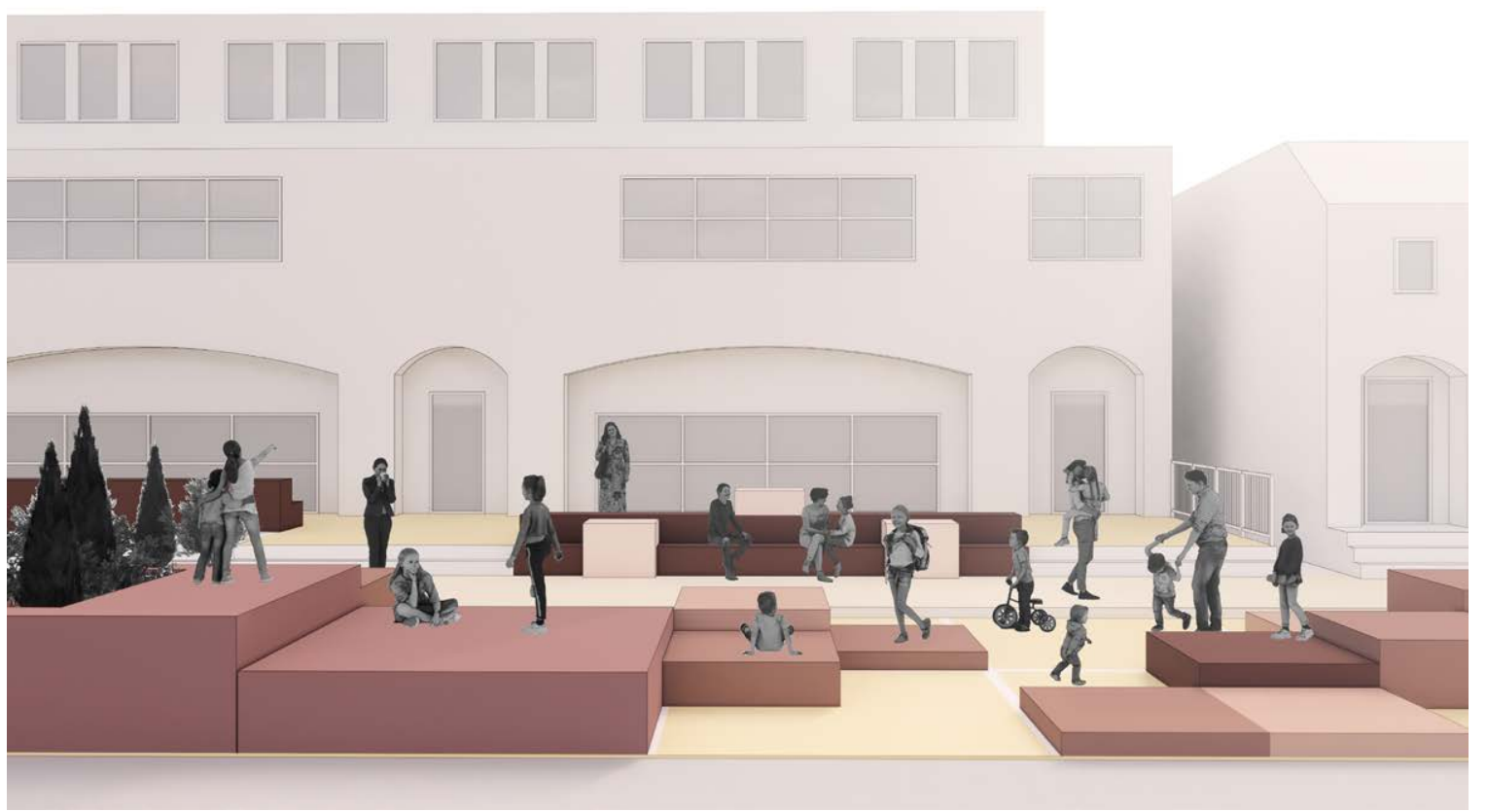

\section{CONCLUSION}

The thesis began as an exploration of the street. This urban element is a public space accessible to everyone as it occupies much of our cities' surface area. Walking along Bank Street in Ottawa, I became interested in how people inhabit and behave within this public space. It quickly became evident that city-users are attracted to the street for the shops and restaurants sitting at the edges or occupy the street on a daily basis for travelling from one area of the city to another. However, not many are interested in further engaging with this urban element, as there are no hospitable spaces for people to stop and linger. 
While walking along the street and photographing the various spaces that defined it, I came across a series of dismissed and unseen gaps that interrupted the busy pattern of facades along the edges. There are voids between buildings that go unnoticed on our daily walks and drive-by, as well as leftover spaces missing a function or wasting away as parking lots, and oddly shaped pockets lacking adequate infrastructure for people to inhabit. These spaces became the gap typologies analyzed within this thesis: the corne the storefront, the alley and the surface parking lot. Based on the ideas developed by Jane Jacobs and Jan Gehl, as well as the Ottawa's New Official Plan, regarding the need to support public life through a more human-centric urban fabric, this thesis sees the potential of these gaps to offer a series of spaces for interaction and connection along the street.

The thesis project explores four gaps along Bank Street to test their potential for publicness with tactical interventions. Each intervention allows the public to interact, modify and reinvent the design to suit different urban needs a use might experience. The idea is to grant the urban fabric the quality of 'looseness' that Karen Franck and Quentin Steven advocated for. By empowering people to add or take away from the urban fabric, a new city-user can emerge that contributes to the production of the urbanscape - the urban dweller. In time, urban dwellers will find innovative ways to invent and reinvent the city. They might even discover that by negotiating with different agents along the street, they are capable of extending the boundaries of the public realm, expanding this project to other city streets. By filling every gap along every street with spaces that encourage publicness, a continuous public realm can be fostered. But it is important to remember that the emergence of this continuum entails a process of growth and flourishment of both the urban fabric and city-users, so that the future urban dwellers may become active agents of the urban fabric in the making. 


\section{Endnotes}

Karen A. Franck and Quentin Stevens, "Tying Down Loose Space," in Loose Space (Abingdon, Oxon: , 2007), 3 .

City of Ottawa, "New Official Plan Preliminary Draft" (City of Ottawa, November 20, 2020), 43, ttps://engage.ottawa.ca/the-new-official-plan\#: : :text=The\%20new\%200fficial\%20Plan\%20provides,of\%20 over\%201.4\%20million\%20people.

3 City of Ottawa, 2020.

Jane Jacobs, The Death and Life of Great American Cities (New York: Random House, 1961,

https://catalog.hathitrust.org/Record/000341379,

Jan Gehl, Life Between Buildings: Using Public Space (Washington DC, United States: Island Press,

2011), http://ebookcentral.proquest.com/lib/oculcarleton-ebooks/detail.action?doclD=3317590.

Gehl, 2011: 9 .

Gehl, 2011: 9.

Jacobs, 1961: 117

Gehl, 2011: 9.

Gehl, 2011: $12-13$.

Jacobs, 1961: 117-22.

Gert-Jan Hospers, "Jane Jacobs: Her Life and Work," European Planning Studies 14, no. 6 (July

2006): 726, https://doi.org/10.1080/09654310600779444.

$14 \quad$ Gehl, 2011: 47

15 Online Etymology Dictionary “Origin and Meaning of Street”" Online Etymology Dictionary

accessed January 29, 2021, https.//wwwetymonline com/word/street.

16 Joseph Stromberg, "The Forgotten History of How Automakers Invented the Crime of

"laywalking,", Vox, January 15, 2015, https://www.vox.com/2015/1/15/7551873/jaywalking-history.

17 City of Ottawa, 2020: 31.

19 Toon Dresden, "Dreessen: Ottawa's Official Plan Is Bold. Will City Council Be Bold Too?," Ottawa Citizen, accessed December 27, 2020, https://ottawacitizen.com/opinion/columnists/dreessen-ottawasofficial-plan-is-bold-will-city-council-be-bold-too.

20 Katherine DeClerq, "Ontario Orders All Non-Essential Businesses to Shut Down," Toronto, March 23, 2020, https://toronto.ctvnews.ca/ontario-orders-all-non-essential-businesses-to-shut-down-1.4864492. 21 Oliver Moore, "Toronto, Vancouver Look into Closing Roads to Traffic to Create Space for Social Distancing," accessed November 23, 2020, https://www.theglobeandmail.com/canada/article-toronto-

2 Joanne Chianello, "Mayor Unmoved by Calls to Open Roads to Pedestrians I CBC News," CBC, April 7, 2020, https://www.cbc.ca/news/canada/ottawa/mayor-jim-watson-not-open-roads-covid-1.5524794. 23. Natalia Goodwin, A Wonderful Surprise'. Ottawans Flock to Closed-off Queen Elizabeth

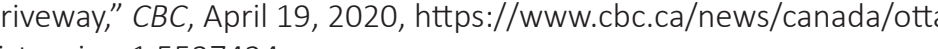
distancing- 1.5537424

24 David Sim, Soft City Building Density for Everyday Life (Washington: Islander Press, 2019), 103.
26 Jacobs, 1961: 150-51.

27 CUI, "The Value of Investing in Canadian Downtowns," 2013, 16, https://canurb.org/publications/ the-value-of-investing-in-canadian-downtowns/.

28 ONS, "Centretown," Ottawa Neighbourhood Study, accessed November 22, 2020, https://www. neighbourhoodstudy.ca/24centretown/.

29 ONS, "Centretown."

30 Glebe Community Association, "History," Glebe Community Association (blog), accessed October 6, 2020, https://glebeca.ca/history/.

31 ONS, "Old Ottawa South," Ottawa Neighbourhood Study, accessed November 22, 2020, https:// www.neighbourhoodstudy.ca/83old-ottawa-south/

32 Gehl, 2011: 129.

33 ONS, "Centretown." 34 ONS, "Walk and Bike Scores," Ottawa Neighbourhood Study, accessed November 22, 2020, https://www.neighbourhoodstudy.ca/more_info18/.

https://www.neighbourho

36 Roman Mars, “Unpleasant Design \& Hostile Urban Architecture," accessed December 13, 2020, https://99percentinvisible.org/episode/unpleasant-design-hostile-urban-architecture/.

37 Sarah Ross, Archisuit, Tools for Action, CCA, accessed November 21, 2020, https://www.cca.qc.ca/ actions/actions/foamy-velour-suits-challenge-authority.

38 Sarah Ross, Archisuits, Sarah Ross, accessed November 21, 2020, https://www.insecurespaces. net/archisuits.html.

39 Franck and Stevens, 2007: 1-4.

Steven Holl Architects, "Storefront for Art and Architecture," Steven Holl Architects, accessed March 18, 2021, https://www.stevenholl.com/visit.

Eran Ben-Joseph, "Lots of Excellence," in Rethinking A Lot (Cambridge, Massachusetts: MIT Press,

Idil Mussa, "Where's Your Permit? Children's Lemonade Stand Shut down in Ottawa," CBC, July 3 016, https://www.cbc.ca/news/canada/ottawa/ottawa-ncc-shuts-down-lemonade-stand-1.3662830. $44 \quad F r a n c k$ and Stevens, "Tying Down Loose Space," 23.

45 Amen Jafri, The City That Fun Forgot? (Ottawa, 2014), https://www.youtube.com/watch?v=CKk kRSTaOc.

46 City of Ottawa, "New Official Plan Preliminary Draft," 7.

neurs to Set up Shop, CBC, June 5, 2017, https://www.cbc.ca/news/canada/ottawa/ncc-kids-kiosks-parkway-1.4146027.

$48 \quad$ Franck and Stevens, "Tying Down Loose Space," 10-11.

50 David Roberts, "Barcelona Wants to Build 500 Superblocks. Here's What It Learned from the First Ones.," Vox, Apriil 9, 2019, https://www.vox.com/energy-and-environment/2019/4/9/18273894/ (Robans 
52 Salvador Rueda, "La Supermanzana, nueva celula urbana para la construccion de un nuevo modelo funcional y urbanistico de Barcelona," November 16, 2016, 43.

53 Roberts, "Barcelona Wants to Build 500 Superblocks. Here's What It Learned from the First

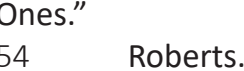

55 Rueda, "La Supermanzana, nueva celula urbana para la construccion de un nuevo modelo funcional y urbanistico de Barcelona," 34

$56 \quad$ Franck and Stevens, "Tying Down Loose Space," 29.

57 Saskia Sassen, "Complex and Incomplete Spaces for Tactical Urbanism," in Uneven Growth

Tactical Urbanism for Expanding Megacities, by Pedro Gadanho (New York: The Museum of Modern Art, 2012), 46

58 City of Ottawa, “New Official Plan Preliminary Draft."

59 City of Ottawa, 96.

60 City of Ottawa, 19.

61 ONS, "Centretown."

ONS, "Old Ottawa South." 


\section{BILIOGRAPHY}

Ben-Joseph, Eran. "Lots of Excellence." In Rethinking A Lot, 99-137. Cambridge, Massachusetts: MIT Press, 2012.

Chianello, Joanne. "Mayor Unmoved by Calls to Open Roads to Pedestrians | CBC News." CBC, April 7, 2020. https://www.cbc.ca/news/canada/ottawa/mayor-jim-watson-notopen-roads-covid-1.5524794.

City of Ottawa. "New Official Plan Preliminary Draft." City of Ottawa, November 20, 2020 https://engage.ottawa.ca/the-new-official-plan\#: :text=The\%20new\%200fficial\%20 Plan\%20provides,of\%20over\%201.4\%20million\%20people.

CUI. "The Value of Investing in Canadian Downtowns," 2013. https://canurb.org/ publications/the-value-of-investing-in-canadian-downtowns/.

DeClerq, Katherine. "Ontario Orders All Non-Essential Businesses to Shut Down." Toronto, March 23, 2020. https://toronto.ctvnews.ca/ontario-orders-all-non-essentialbusinesses-to-shut-down-1.4864492.

Dresden, Toon. "Dreessen: Ottawa's Official Plan Is Bold. Will City Council Be Bold Too?" Ottawa Citizen. Accessed December 27, 2020. https://ottawacitizen.com/opinion/ columnists/dreessen-ottawas-official-plan-is-bold-will-city-council-be-bold-too.

Franck, Karen A., and Quentin Stevens. "Tying Down Loose Space." In Loose Space, 1-34. Abingdon, Oxon: Routledge, 2007

Gehl, Jan. Life Between Buildings: Using Public Space. Washington DC, United States: Island Press, 2011. http://ebookcentral.proquest.com/lib/oculcarleton-ebooks/detail. action?doc $1 \mathrm{D}=3317590$
Glebe Community Association. "History." Glebe Community Association (blog). Accessed October 6, 2020. https://glebeca.ca/history/.

Goodwin, Natalia. “'A Wonderful Surprise': Ottawans Flock to Closed-off Queen Elizabeth Driveway." CBC, April 19, 2020. https://www.cbc.ca/news/canada/ottawa/ottawacovid19-streets-physical-distancing-1.5537424.

Hospers, Gert-Jan. "Jane Jacobs: Her Life and Work." European Planning Studies 14, no. 6 (July 2006): 723-32. https://doi.org/10.1080/09654310600779444.

Jacobs, Jane. The Death and Life of Great American Cities. New York: Random House, 1961 https://catalog.hathitrust.org/Record/000341379.

Jafri, Amen. The City That Fun Forgot? Ottawa, 2014. https://www.youtube.com/ watch?v=CKk_kRSTaOc.

Mars, Roman. "Unpleasant Design \& Hostile Urban Architecture." Accessed December 13, 2020. https://99percentinvisible.org/episode/unpleasant-design-hostile-urbanarchitecture/

Moore, Oliver. "Toronto, Vancouver Look into Closing Roads to Traffic to Create Space for Social Distancing." Accessed November 23, 2020. https://www.theglobeandmail.com/ canada/article-toronto-vancouver-look-into-closing-roads-to-traffic-to-create-space/.

Mussa, Idil. "Where's Your Permit? Children's Lemonade Stand Shut down in Ottawa." CBC, July 3, 2016. https://www.cbc.ca/news/canada/ottawa/ottawa-ncc-shuts-downlemonade-stand-1.3662830

Online Etymology Dictionary. "Origin and Meaning of Street." Online Etymology Dictionary. 
Accessed January 29, 2021. https://www.etymonline.com/word/street.

ONS. "Centretown." Ottawa Neighbourhood Study. Accessed November 22, 2020. https:// www.neighbourhoodstudy.ca/24centretown/.

- - - . "Old Ottawa South." Ottawa Neighbourhood Study. Accessed November 22, 2020. https://www.neighbourhoodstudy.ca/83old-ottawa-south/.

- - - "Walk and Bike Scores." Ottawa Neighbourhood Study. Accessed November 22, 2020. https://www.neighbourhoodstudy.ca/more_info18/.

Pritchard, Trevor. "Lemons to Lemonade: NCC Now Inviting Young Entrepreneurs to Set up Shop." CBC, June 5, 2017. https://www.cbc.ca/news/canada/ottawa/ncc-kids-kiosksparkway-1.4146027.

Roberts, David. "Barcelona Wants to Build 500 Superblocks. Here's What It Learned from the First Ones." Vox, April 9, 2019. https://www.vox.com/energy-and environment/2019/4/9/18273894/barcelona-urban-planning-superblocks-poblenou.

Ross, Sarah. Archisuit. Tools for Action. CCA. 2005. https://www.cca.qc.ca/actions/actions/ foamy-velour-suits-challenge-authority.

Ross, Sarah. "Archisuits." Sarah Ross. Accessed November 21, 2020. https://www. insecurespaces.net/archisuits.html.

Rueda, Salvador. "La Supermanzana, nueva celula urbana para la construccion de un nuevo modelo funcional y urbanistico de Barcelona," November 16, 2016, 43.

Sassen, Saskia. "Complex and Incomplete Spaces for Tactical Urbanism." In Uneven Growth Tactical Urbanism for Expanding Megacities, by Pedro Gadanho, 40-47. New York: The
Museum of Modern Art, 2012

Sim, David. Soft City Building Density for Everyday Life. Washington: Islander Press, 2019. Steven Holl Architects. "Storefront for Art and Architecture." Steven Holl Architects Accessed March 18, 2021. https://www.stevenholl.com/visit.

Stromberg, Joseph. "The Forgotten History of How Automakers Invented the Crime of 'Jaywalking."” Vox, January 15, 2015. https://www.vox.com/2015/1/15/7551873/ jaywalking-history. 